Fall 1948

\title{
1948 Cedrus Yearbook
}

\section{Cedarville College}

Follow this and additional works at: https://digitalcommons.cedarville.edu/yearbooks

Part of the Higher Education Commons, Organizational Communication Commons, and the Public Relations and Advertising Commons

\section{Recommended Citation}

Cedarville College, "1948 Cedrus Yearbook" (1948). Yearbooks. 66.

https://digitalcommons.cedarville.edu/yearbooks/66

This Book is brought to you for free and open access by DigitalCommons@Cedarville, a service of the Centennial Library. It has been accepted for inclusion in Yearbooks by an authorized administrator of DigitalCommons@Cedarville. For more information, please contact digitalcommons@cedarville.edu. 


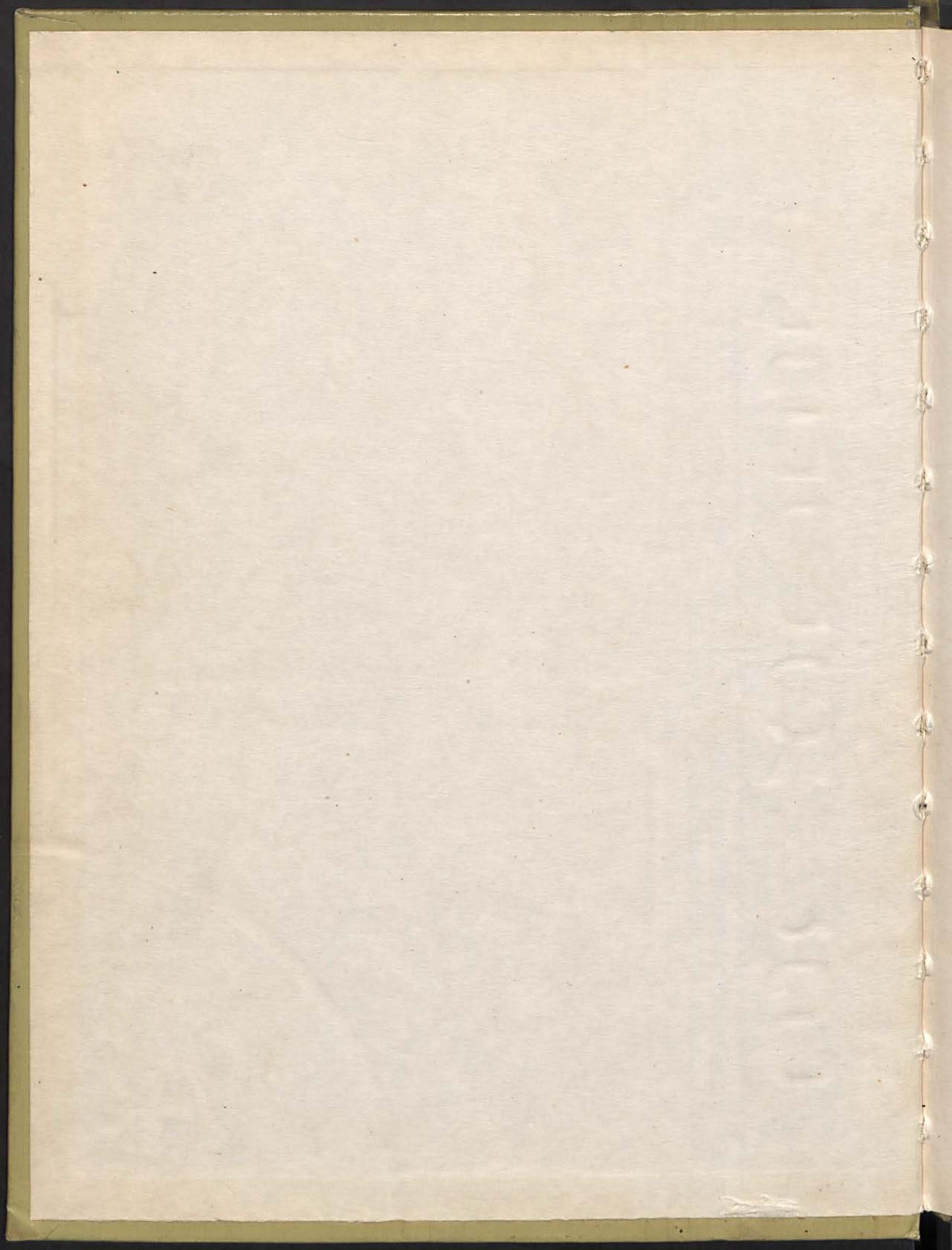





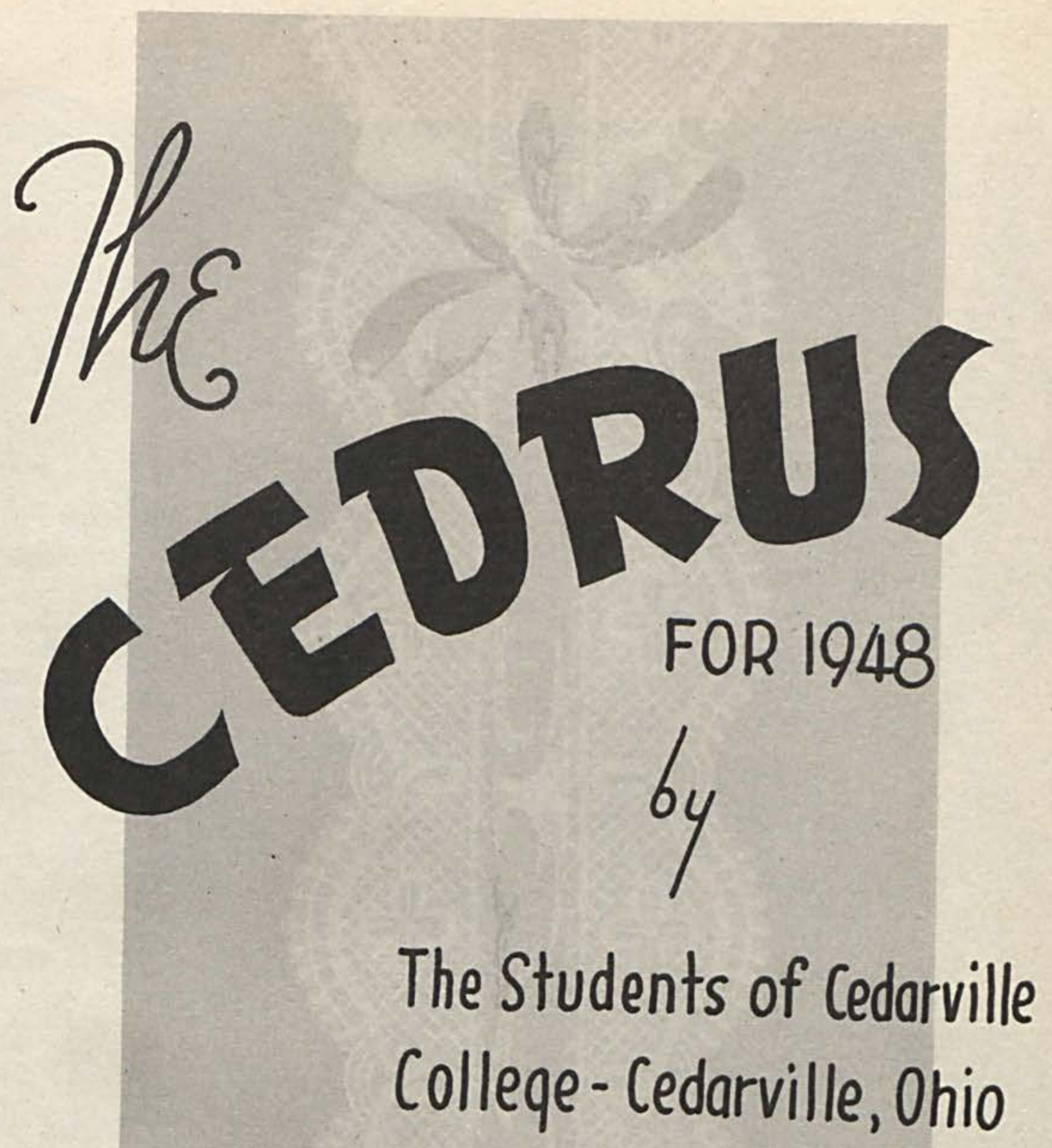




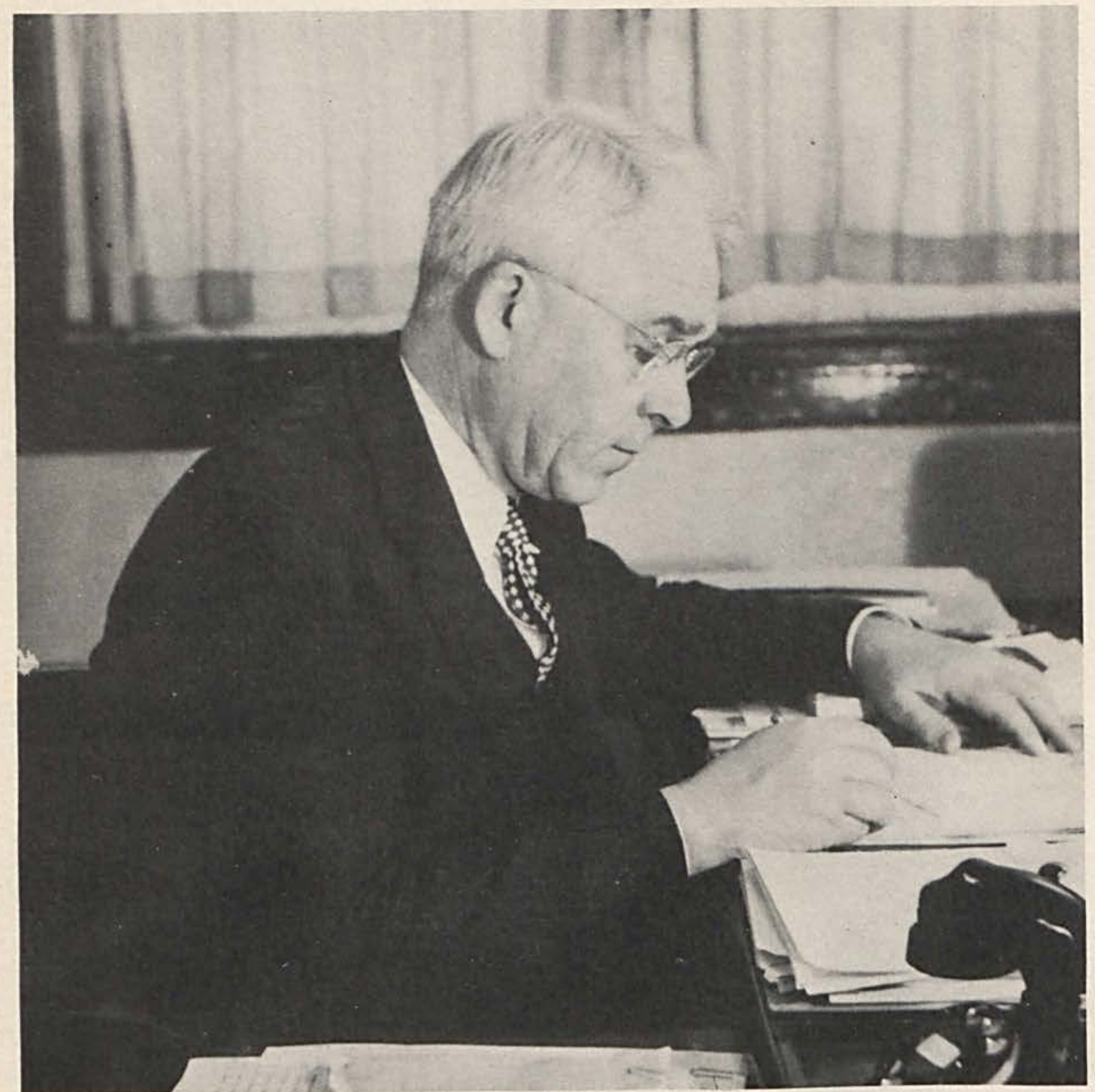

\section{President's Message}

IRA D. VAYHINGER

Cedarville College has come through a depression and the war in splendid shape. During the waryears the current operating budget was balanced; this year it will be over $\$ 100,000$. Our faculty has been enlarged to 15. Our student body has grown until we have 240 different students during the year. Our athletic program has been given wide publicity and attracted many students.

During the war it was impossible to make repairs, renew furnaces or build buildings. Since 1945 we have spent $\$ 10,000$ to replace 7 furnaces, paint the buildings and repair our property. Our need was to house students and provide equipment. Dur ing this period we purchased the Rife House. We received a building from Patterson Field which has been dismantled, brought to our campus and erected into a splendid dormitory for 65 men. We also received a building from the Federal Works Agency for study and recreation. Two laboratory buildings from the Federal Works Agency remain to be erected. War surplus equipment in the amount of approximately $\$ 50,000$ has been received. 


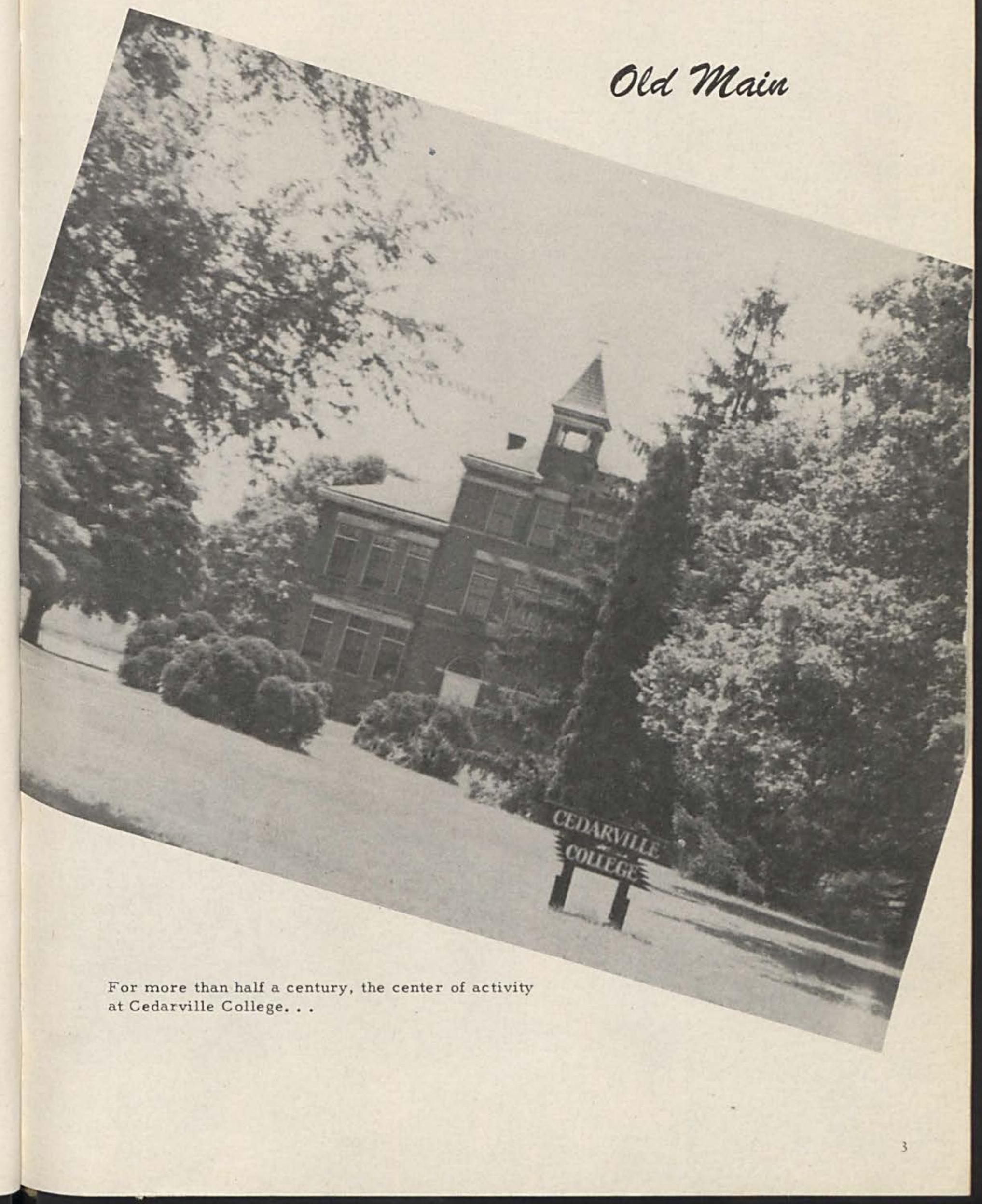





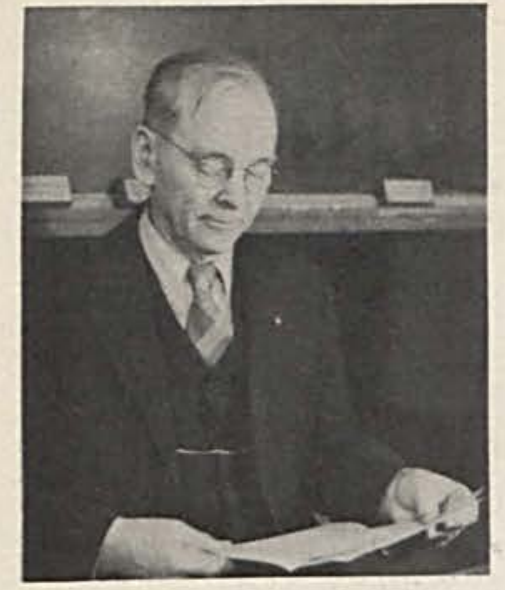

A. J. HOSTETLER, M. A. Director of Dept. of Education.

\section{The \\ Faculty}

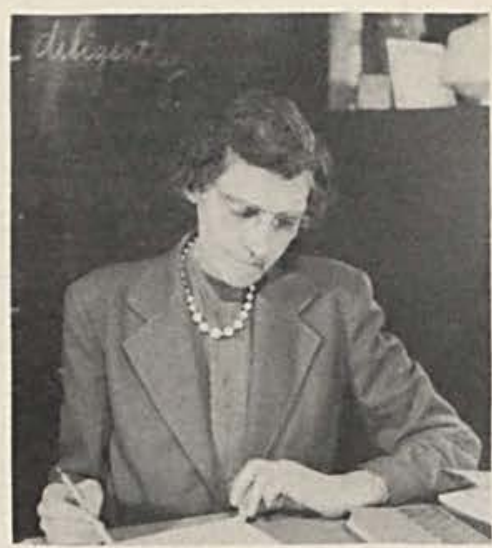

CARRIE M. RIFE, M. A. Speech, Education

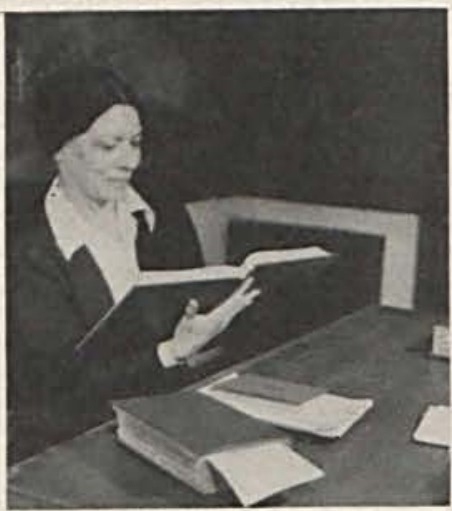

HELEN HOOVEN SANTMYER, B. Litt. Dean of Women; English

FRANK ALBERT JURKAT, LL.D., D. D. Language and Bible
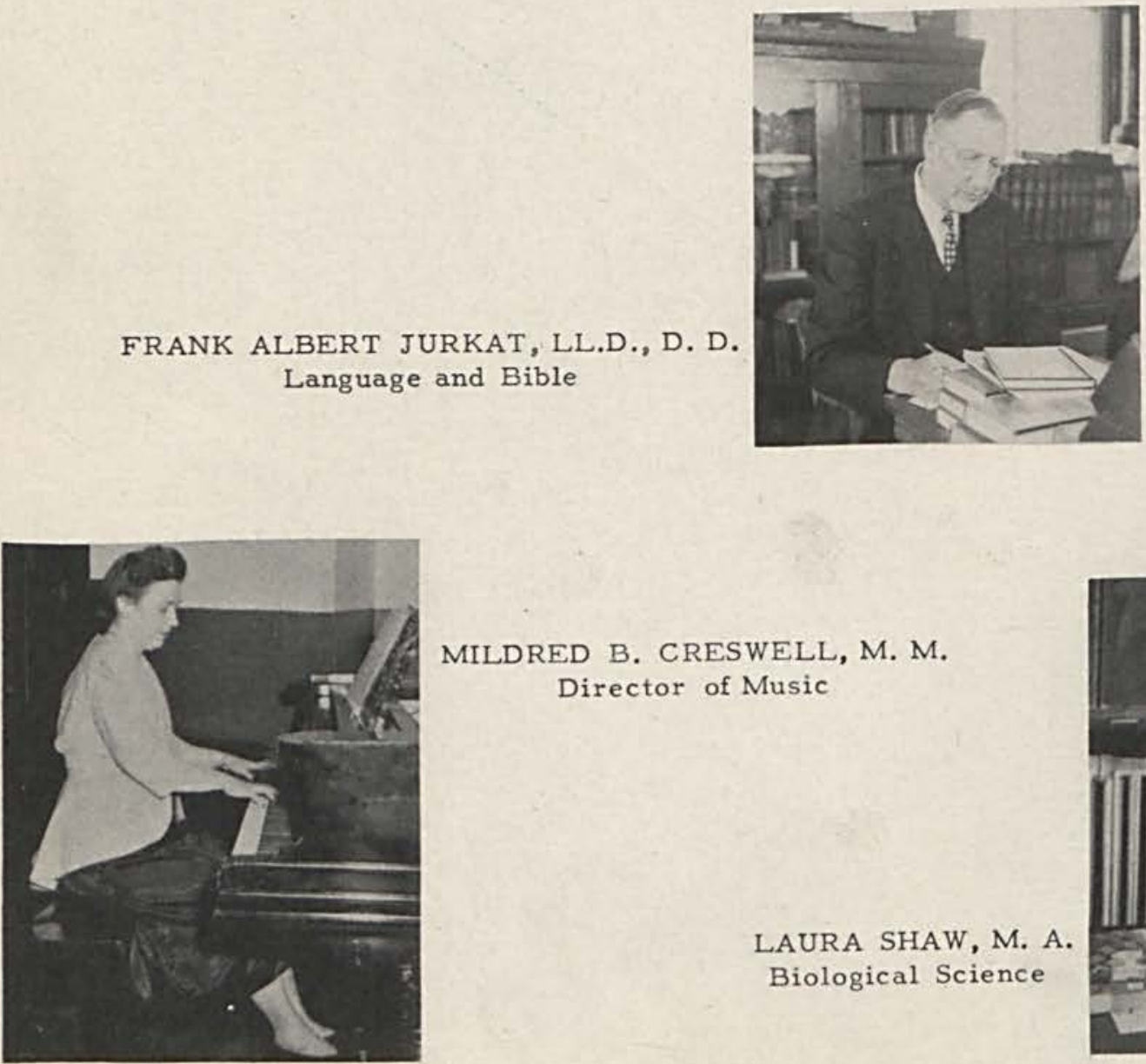

MILDRED B. CRESWELL, M. M. Director of Music

LAURA SHAW, M. A. Biological Science

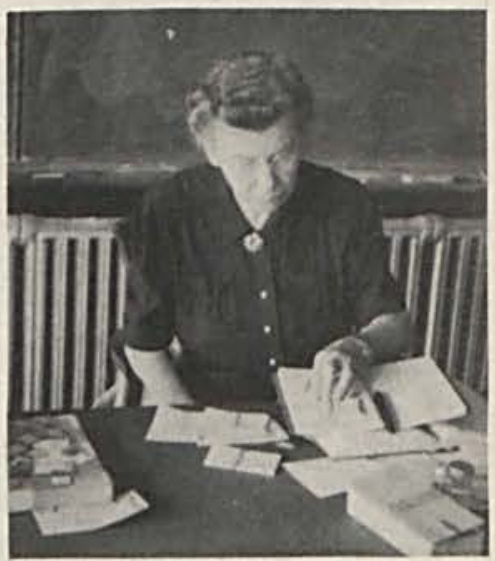




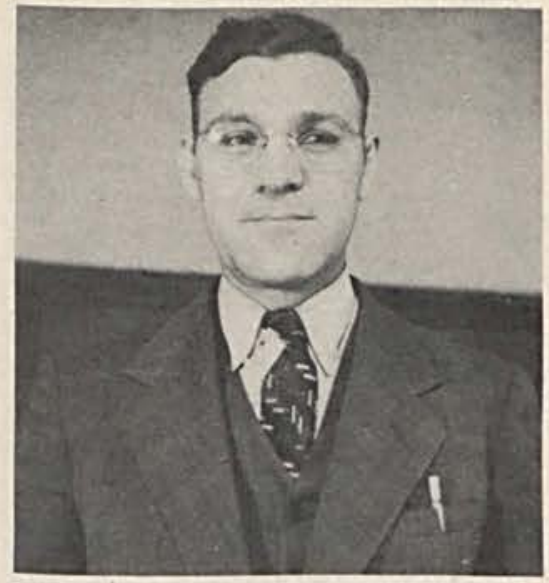

FREDERICK CARLSON, A. B., B. D. Bible, Philosophy, History

DONALD R. EDINGTON, M. A. European History

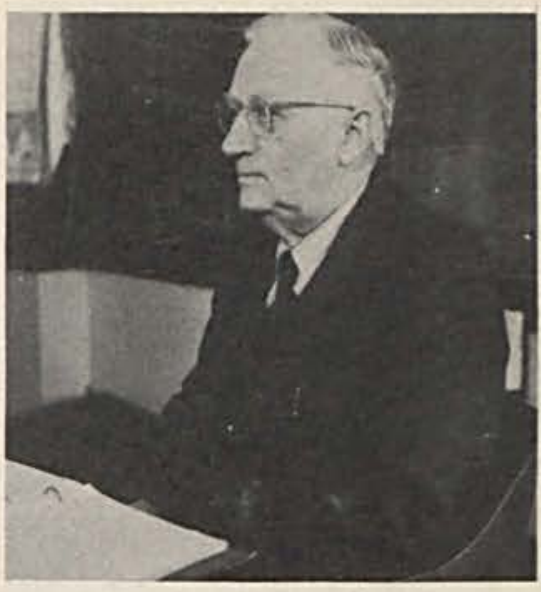

C. W. STEELE, LL. D. American History Dean
JEAN POLLOCK, M. A.

Director Women's Physical Education
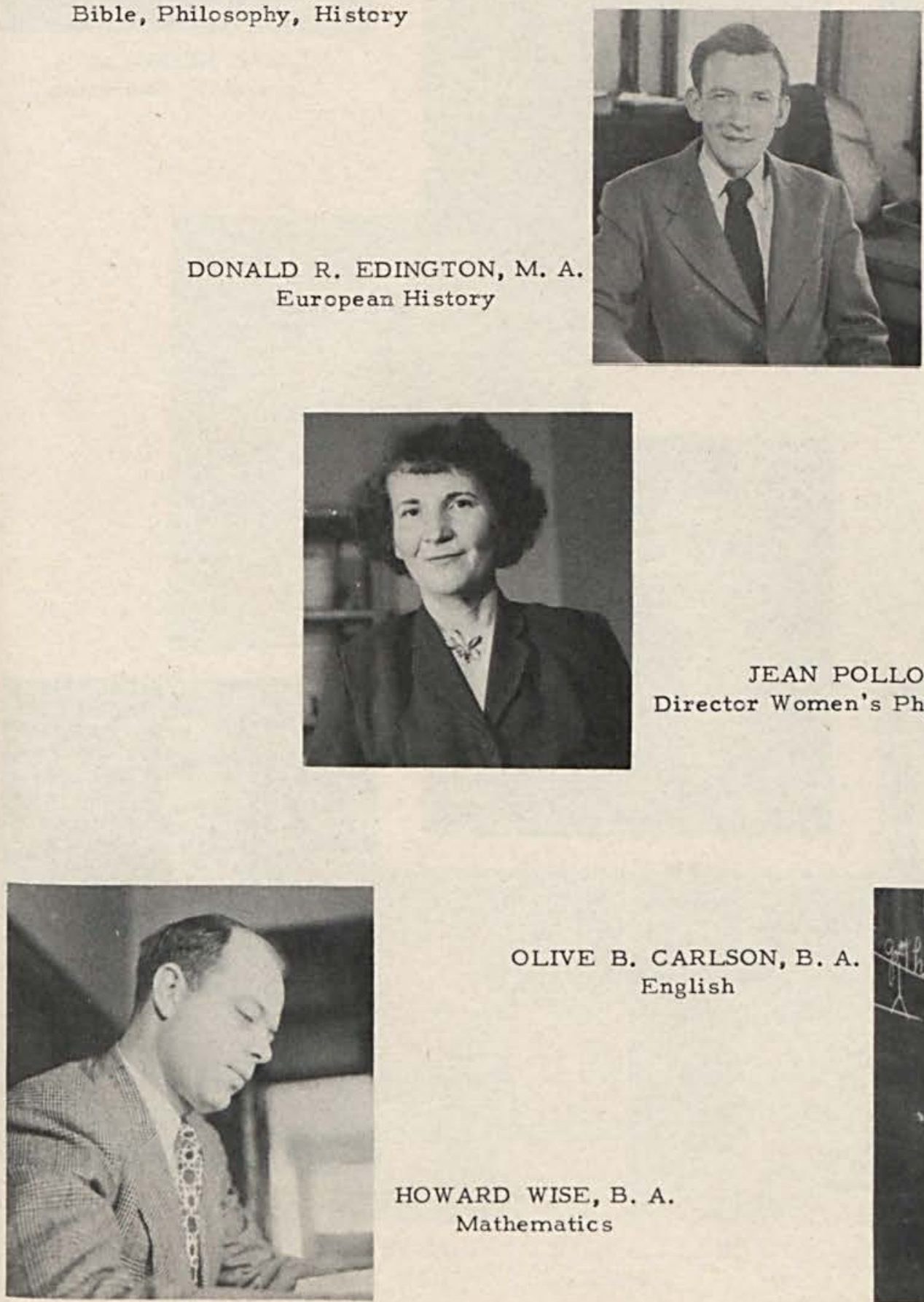

HOWARD WISE, B. A. Mathematics

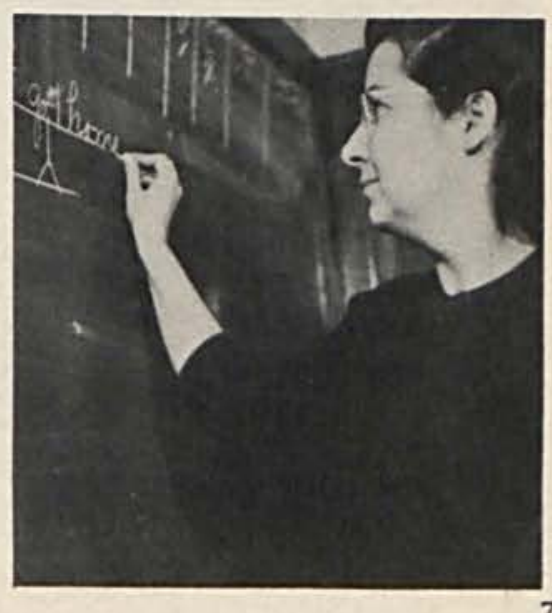




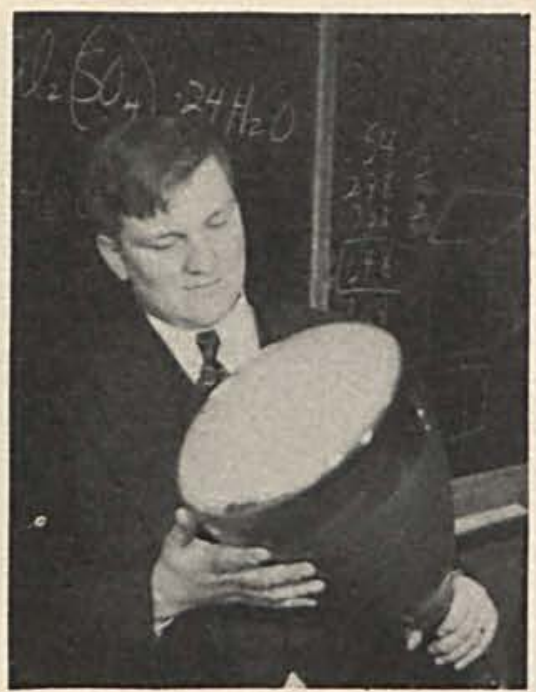

ELWOOD SHAW, B. A., B. S. Physical Sciences

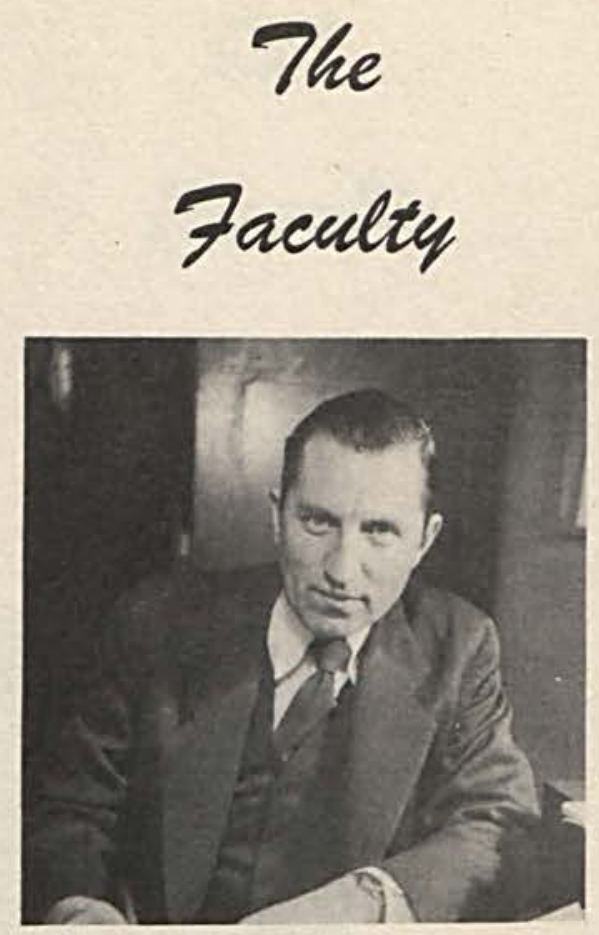

MENDELL E. BEATTIE, B. A. Dean of Men

Director of Athletics

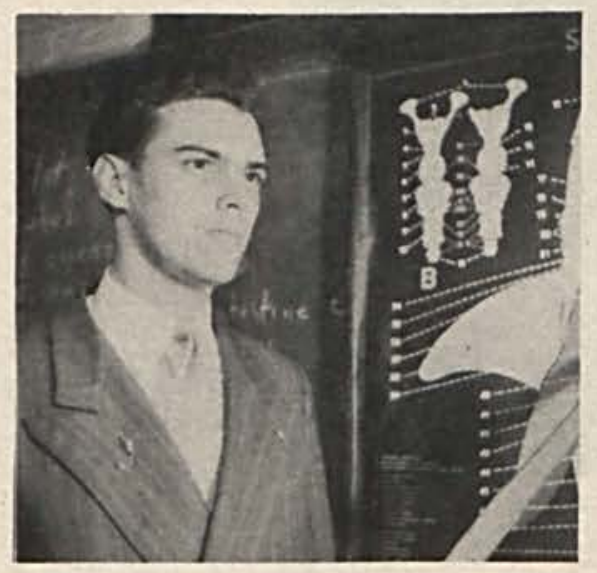

JAMES RAMSEY

Biological Sciences

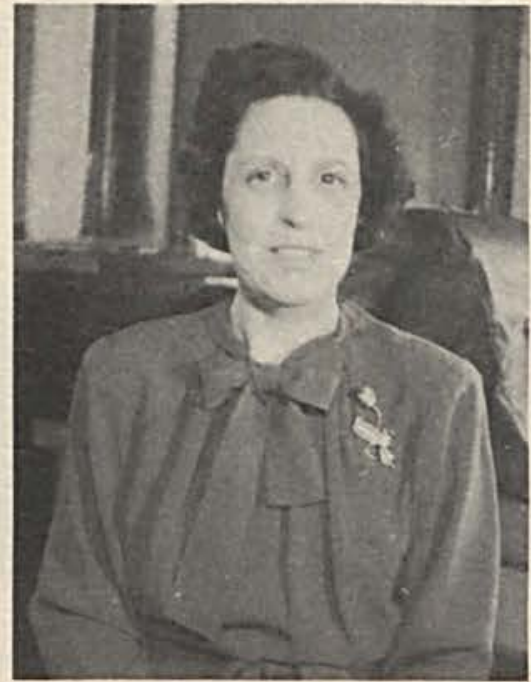

ELOISE KLING, M. A. Elementary Education

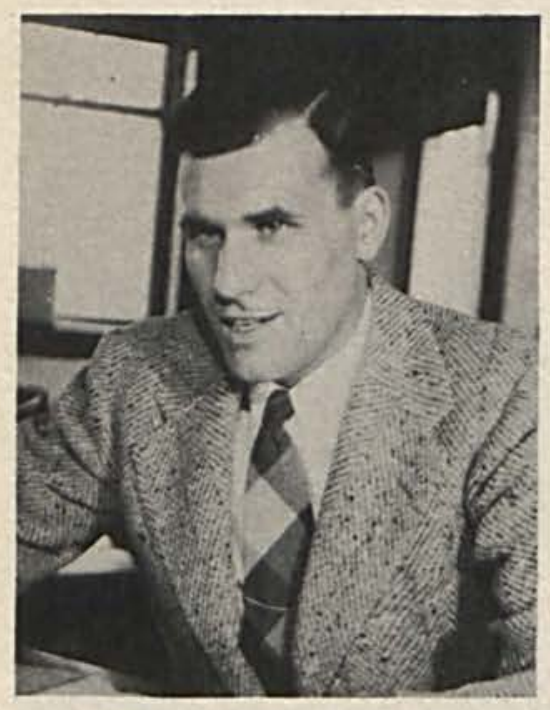

THURMAN MILLER Journalism

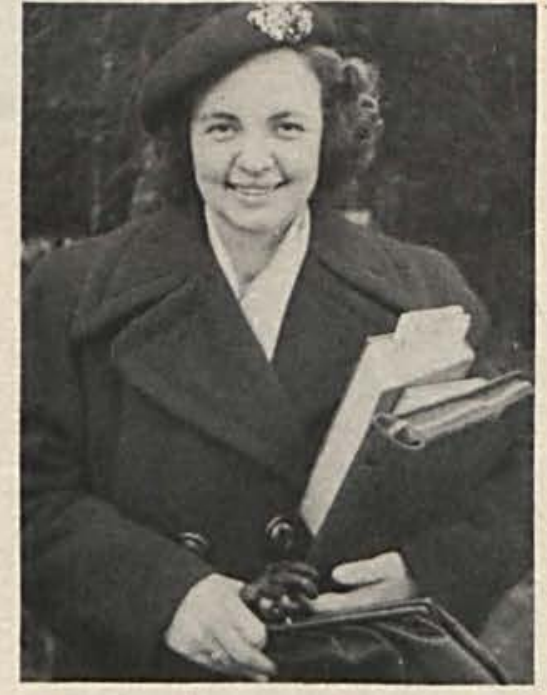

BEATRICE VERMILLION, B. A., B. S. English 


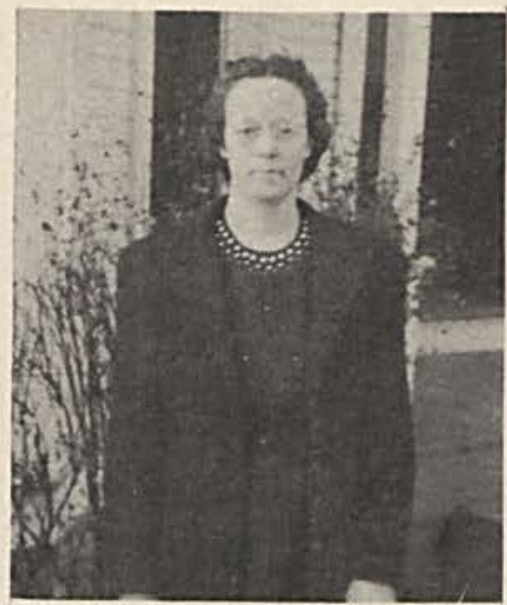

MRS. MENDELL BEATTIE

Dietician

Rife Hall

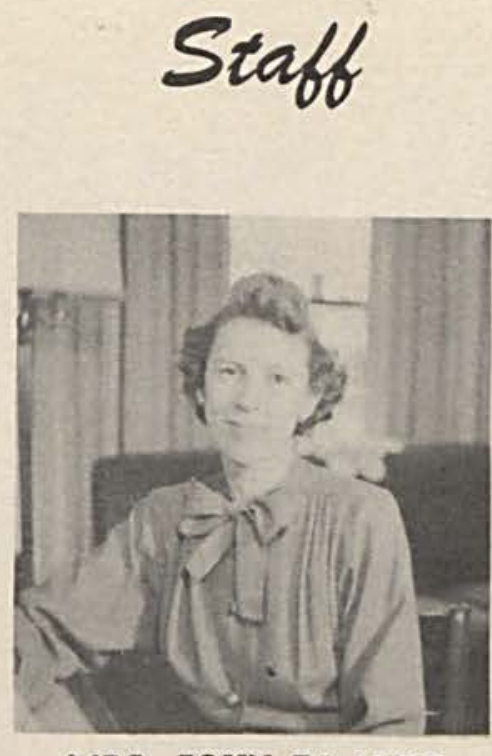

MRS. JOHN BLAZER

Harriman Hall

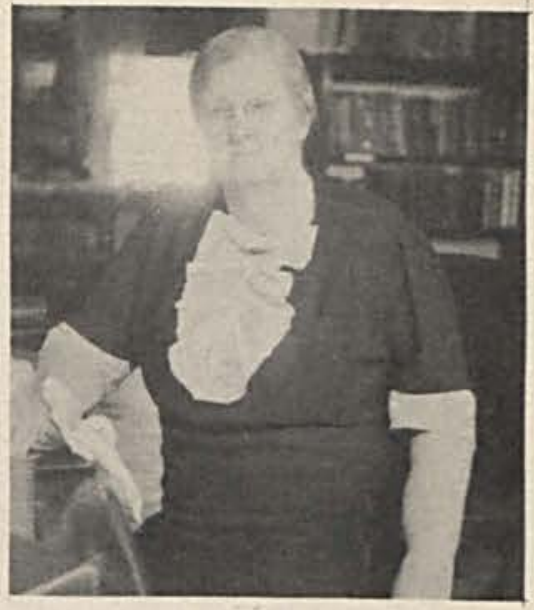

MARY WILLIAMSON Librarian

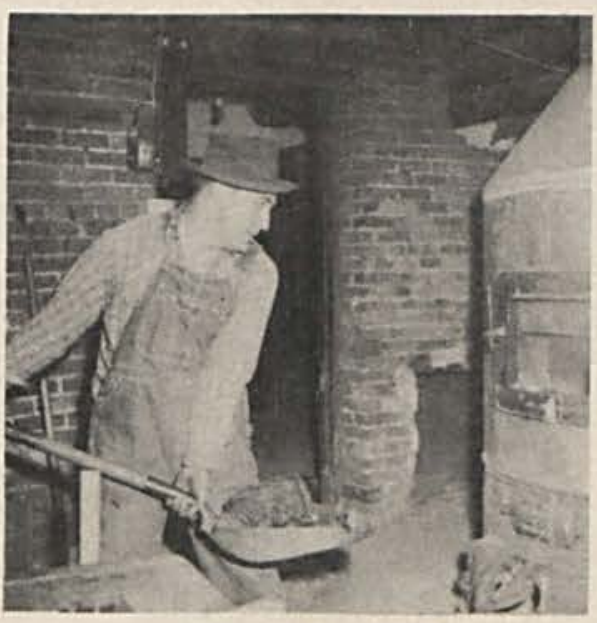

JOHN BLAZER

Supt. Buildings and Grounds

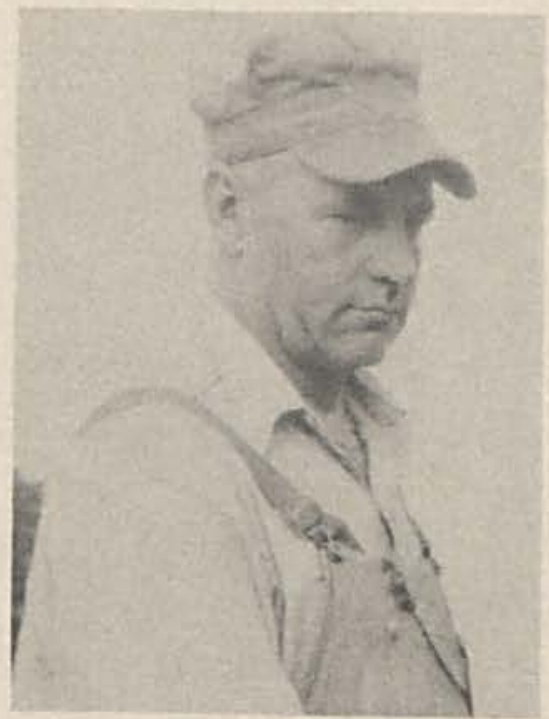

ROY JOCOBS

Farm Superintendent

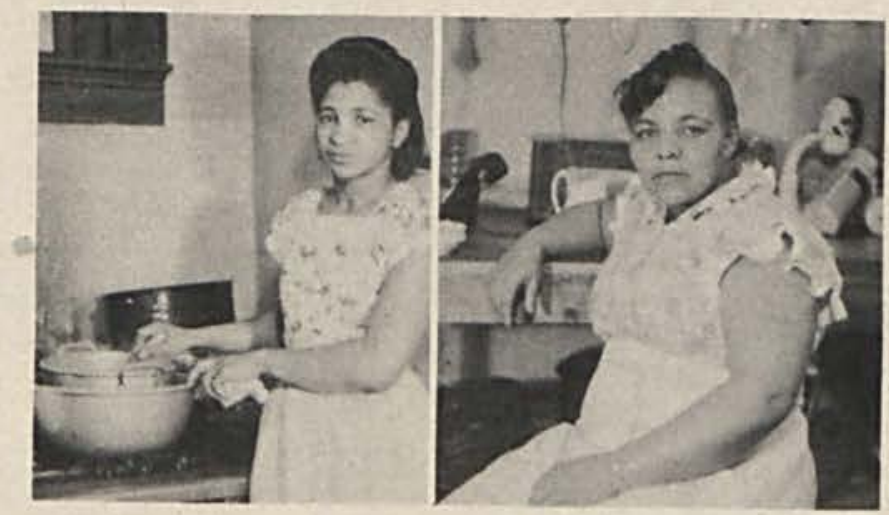

MRS. ROSALINE SMITH and MRS. ANNA BENNETT Cooks 


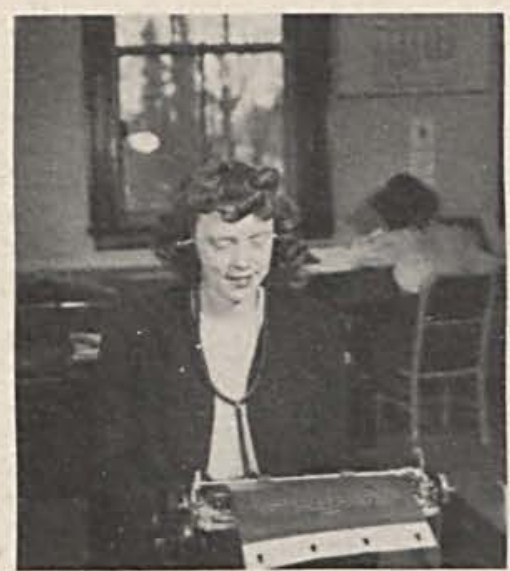

MRS. FLORENCE RADER
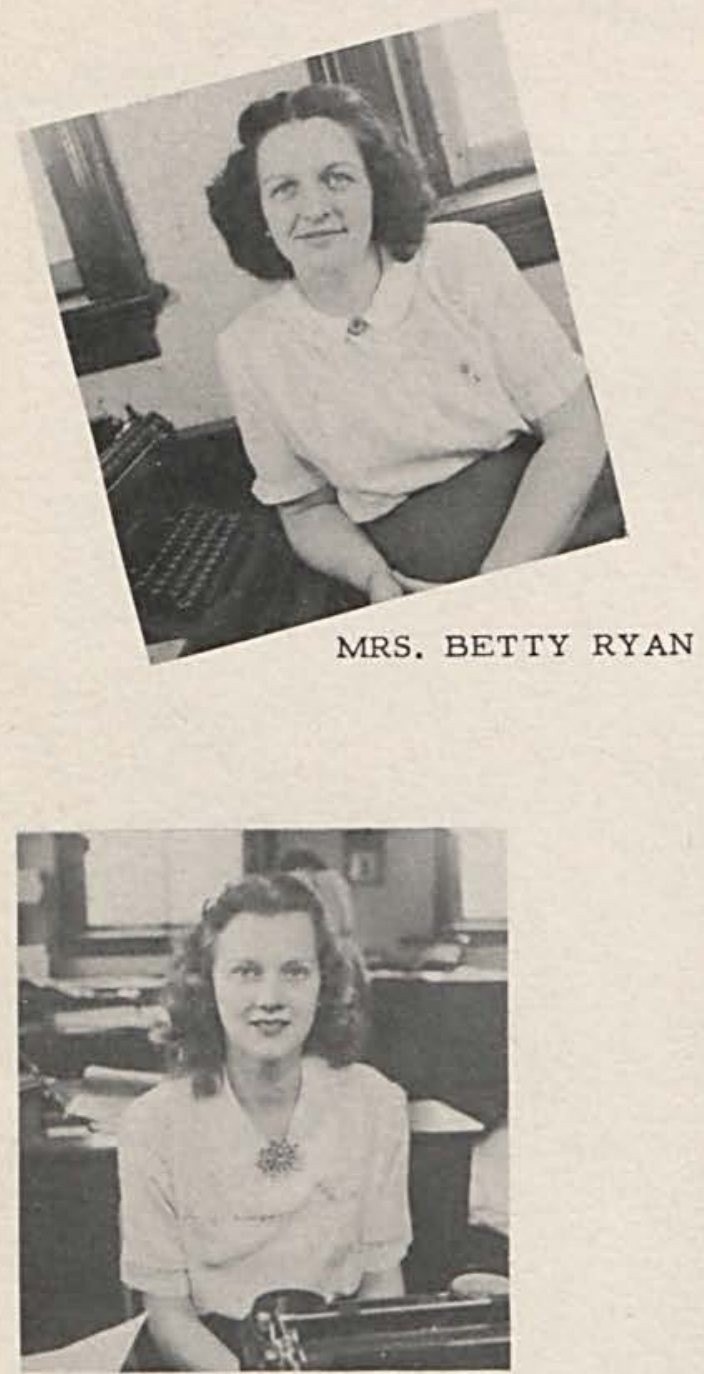

MRS. NANCY BRADFORD
Office Staff

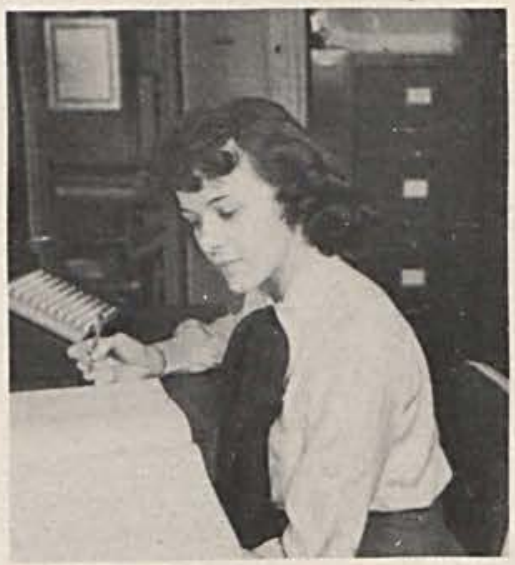

MRS. PAT OSMAN

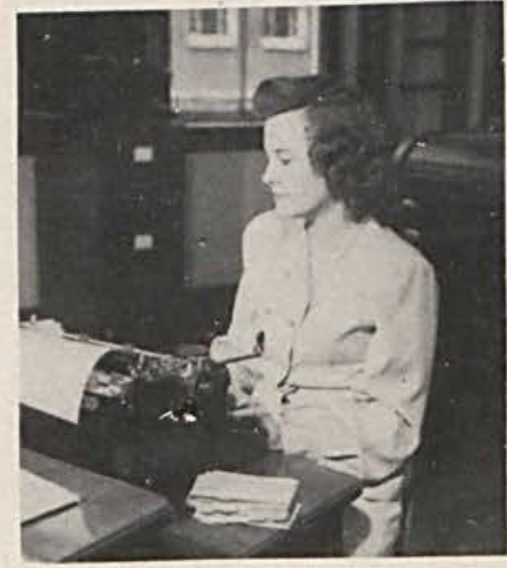

MRS. PEACHY FIFE 

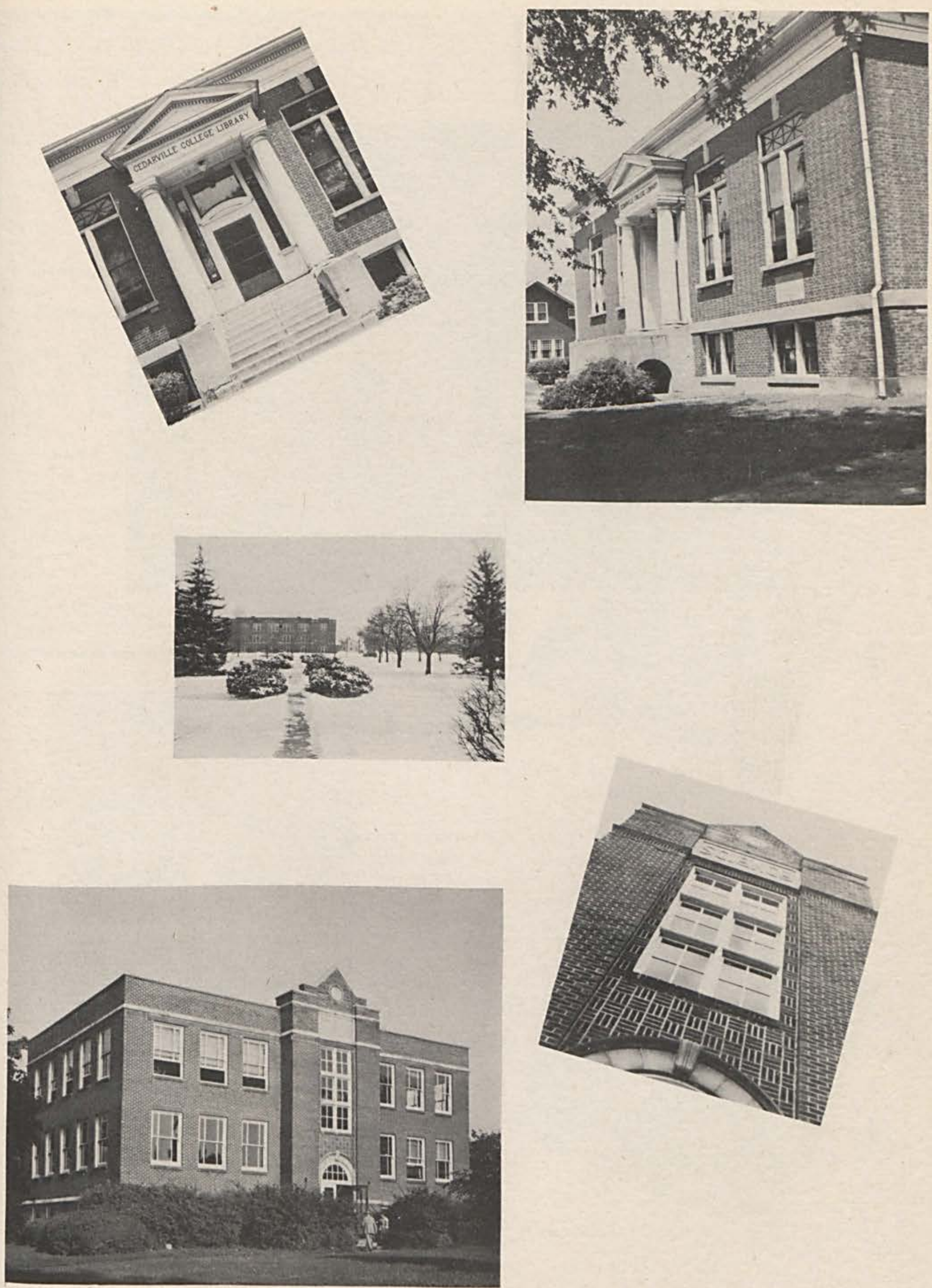


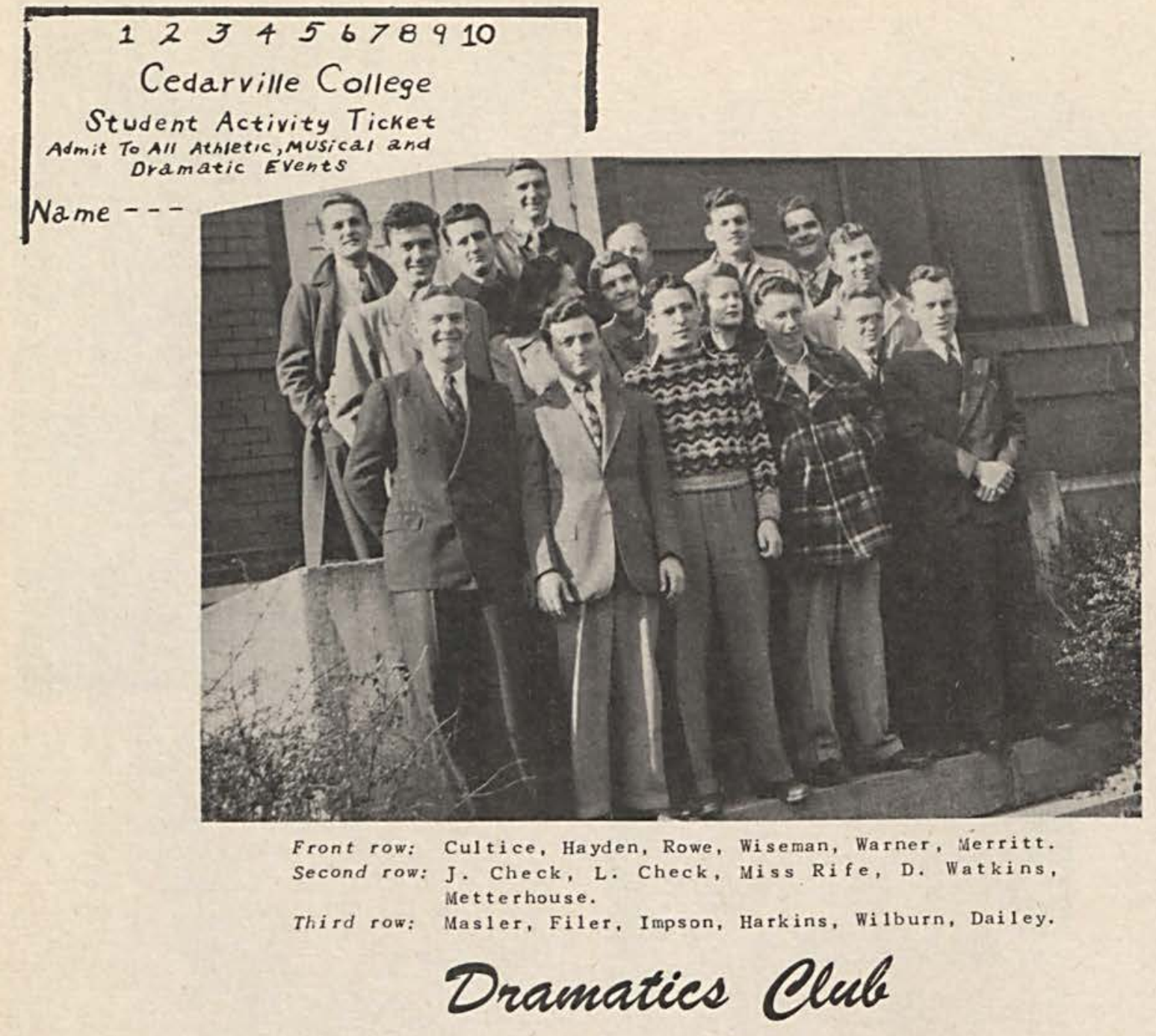

Under the capable direction of Miss Carrie Rife, the Dramatics Club has completed a most entertaining season.

The culmination of many weeks' rehearsals was the night of December 11, when the players presented the American comedy, "The Man Who Came To Dinner", a merciless cartoon of Alexander Woollcott's bad manners, shameless egoism, bountiful mischief, and widely assorted friendships. Arthur "Curly" Harkins did a magnificent impersonation of the eccentric "Man". A cast of twenty-eight appeared in the presentation.

Class room time for the Dramatics Club is spent in the discussion of plays currently appearing on Broadway, recording excerpts from the se plays, and discussing the techniques of play production.

J. C. 

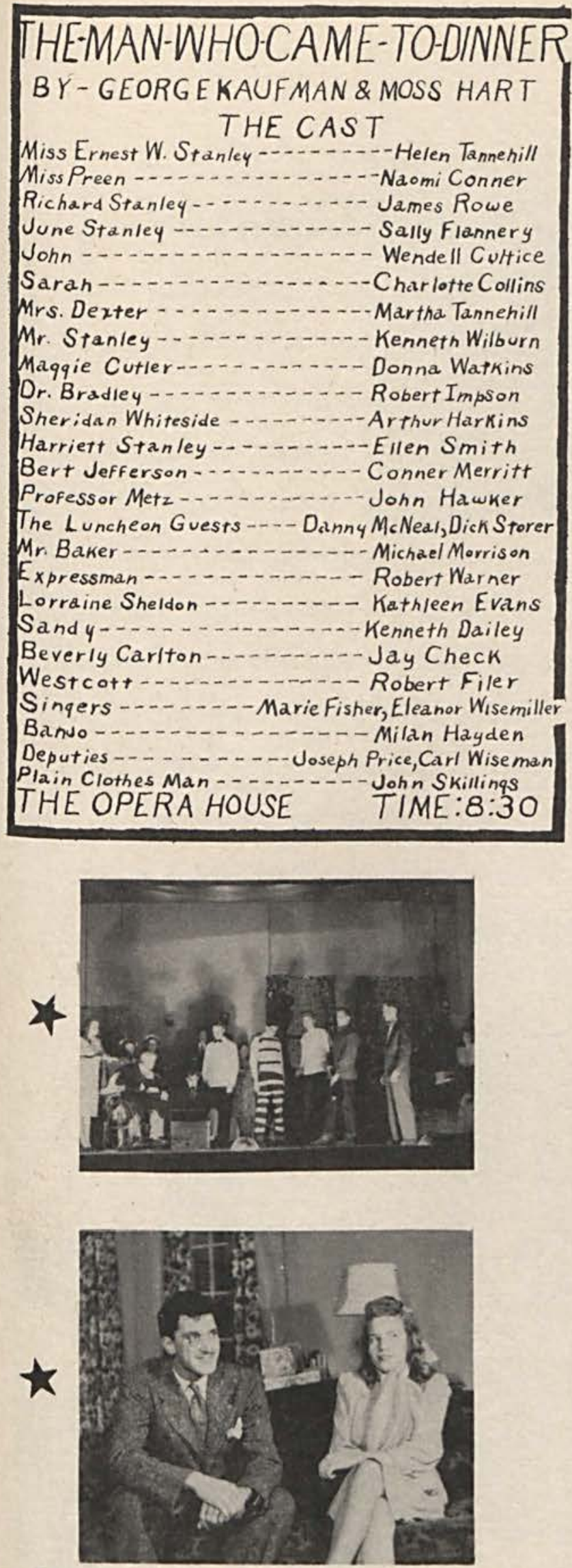

JAY CHECK and MRS. DONNA WATKINS
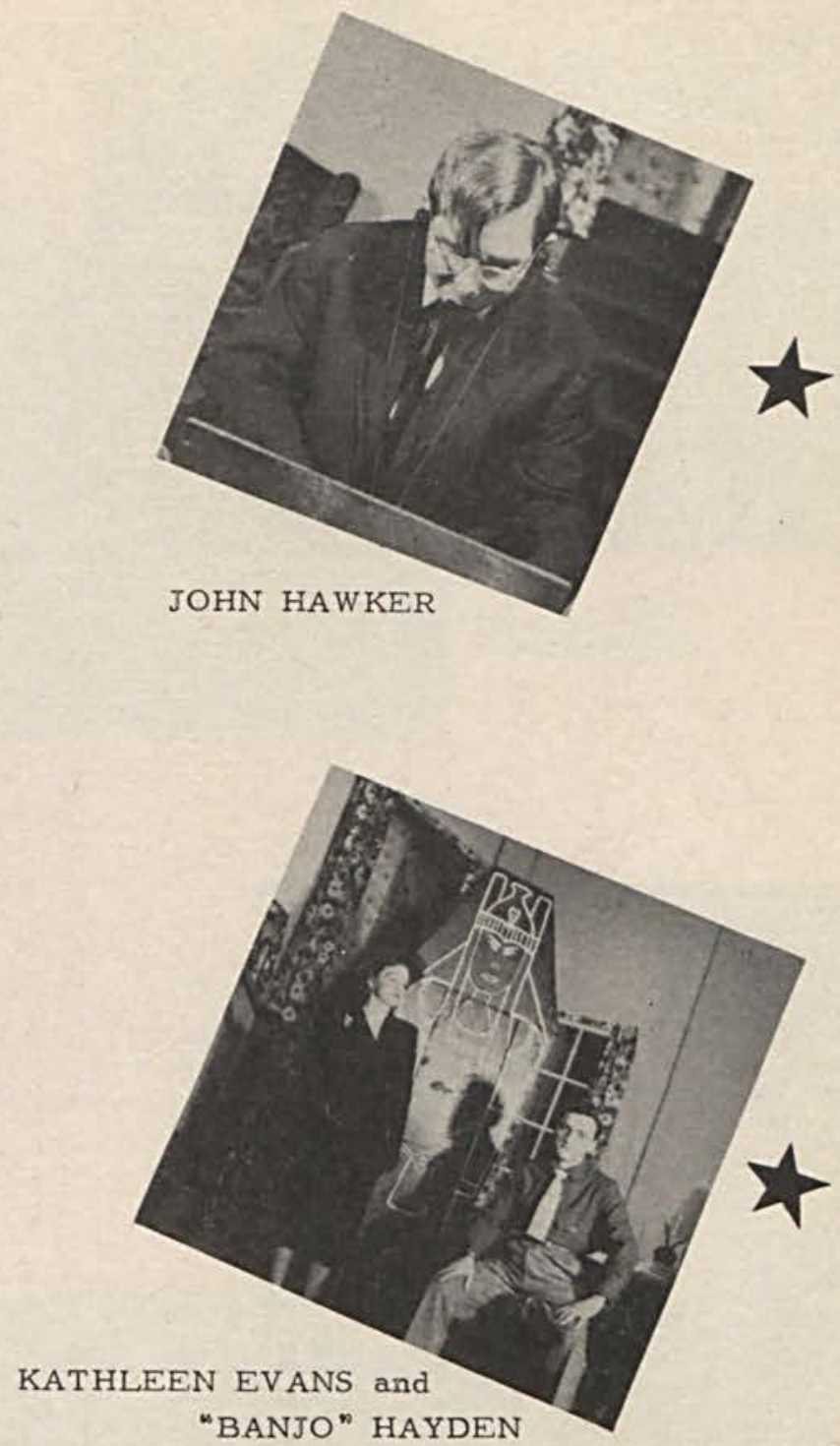

"BANJO" HAYDEN

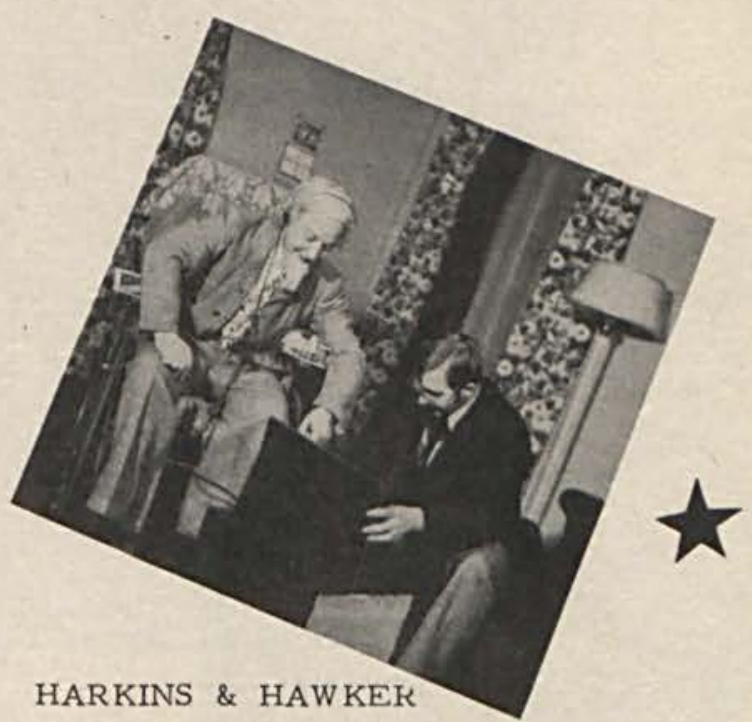




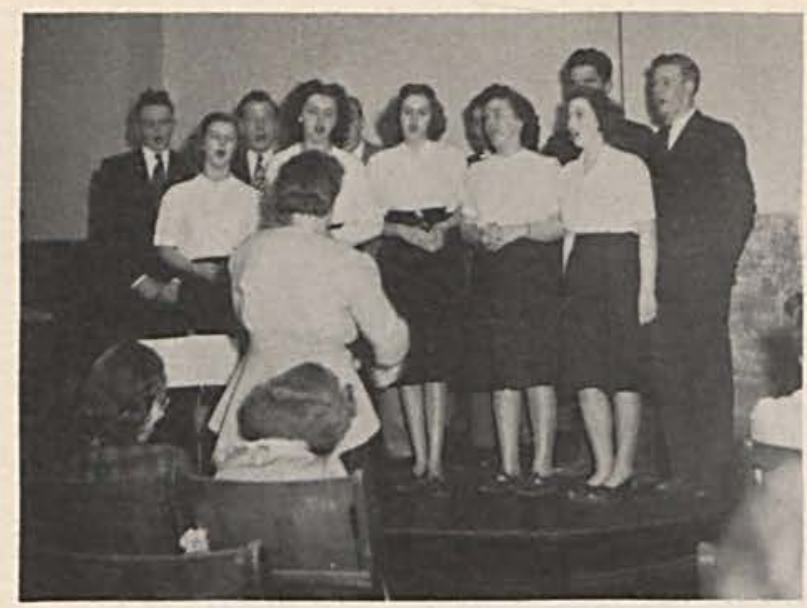

\section{Mixed Charus}

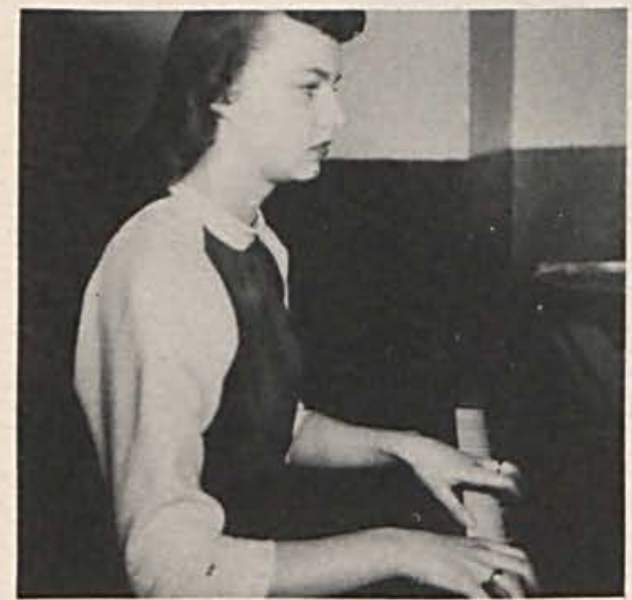

PRACTICE

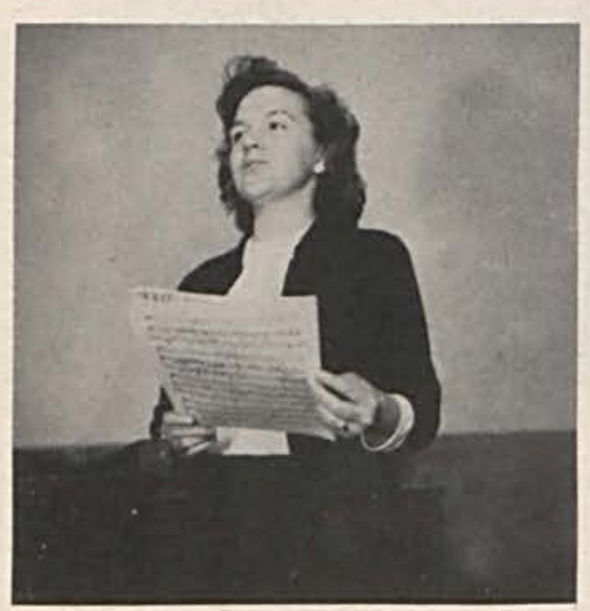

\section{Music Department}

The Cedarville College Mixed Chorus directed by Mrs. Mildred B. Creswell gave several public performances during the year 1947-1948. It sang at the Men's Bible Reading Contest, the Girls' Bible Reading Contest, Baccalaureate, and Commencement. A speçial sacred concert was given in the spring at Cedarville and at churches in two other towns. A splendid group of students enjoyed the activity this year, and the audiences who heard them sing were warm in their praise of the quality of singing done.

Officers of the Mixed Chorus during the first semester were: Arthur Harkins, president; Charlotte Collins, secretary; Kathleen Evans, librarian.

\section{THEORY}

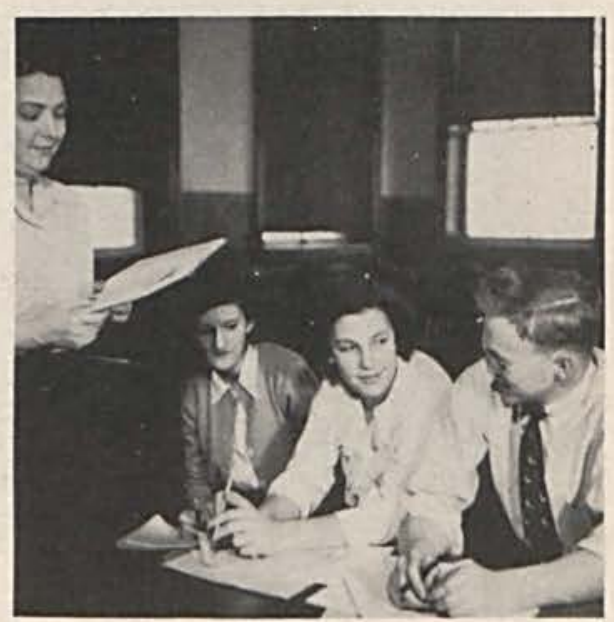




\section{2 uartette}

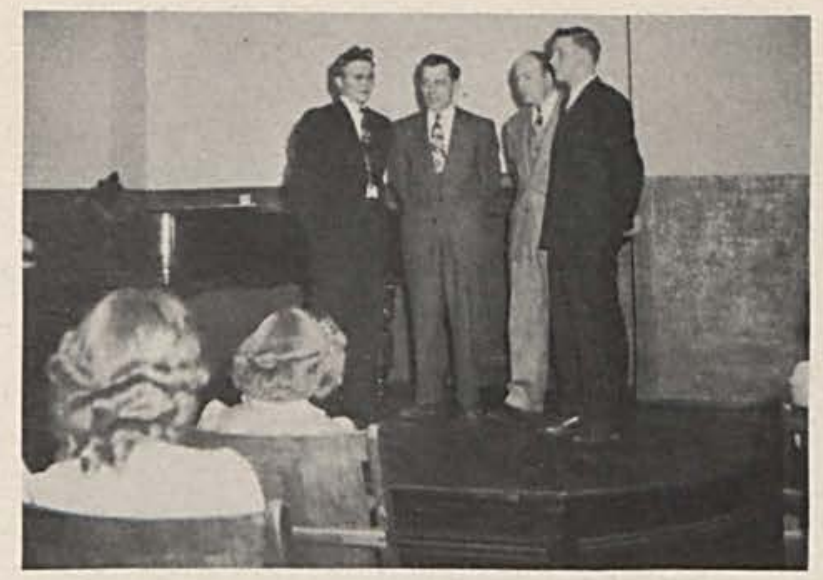

... in chapel

The college quartet was revived in the fall semester and a large repertoire of classical, romantic, and humorous numbers was developed. Besides participating in chapel services, the quartet made frequent appearances at high schools and churches in neighboring towns.

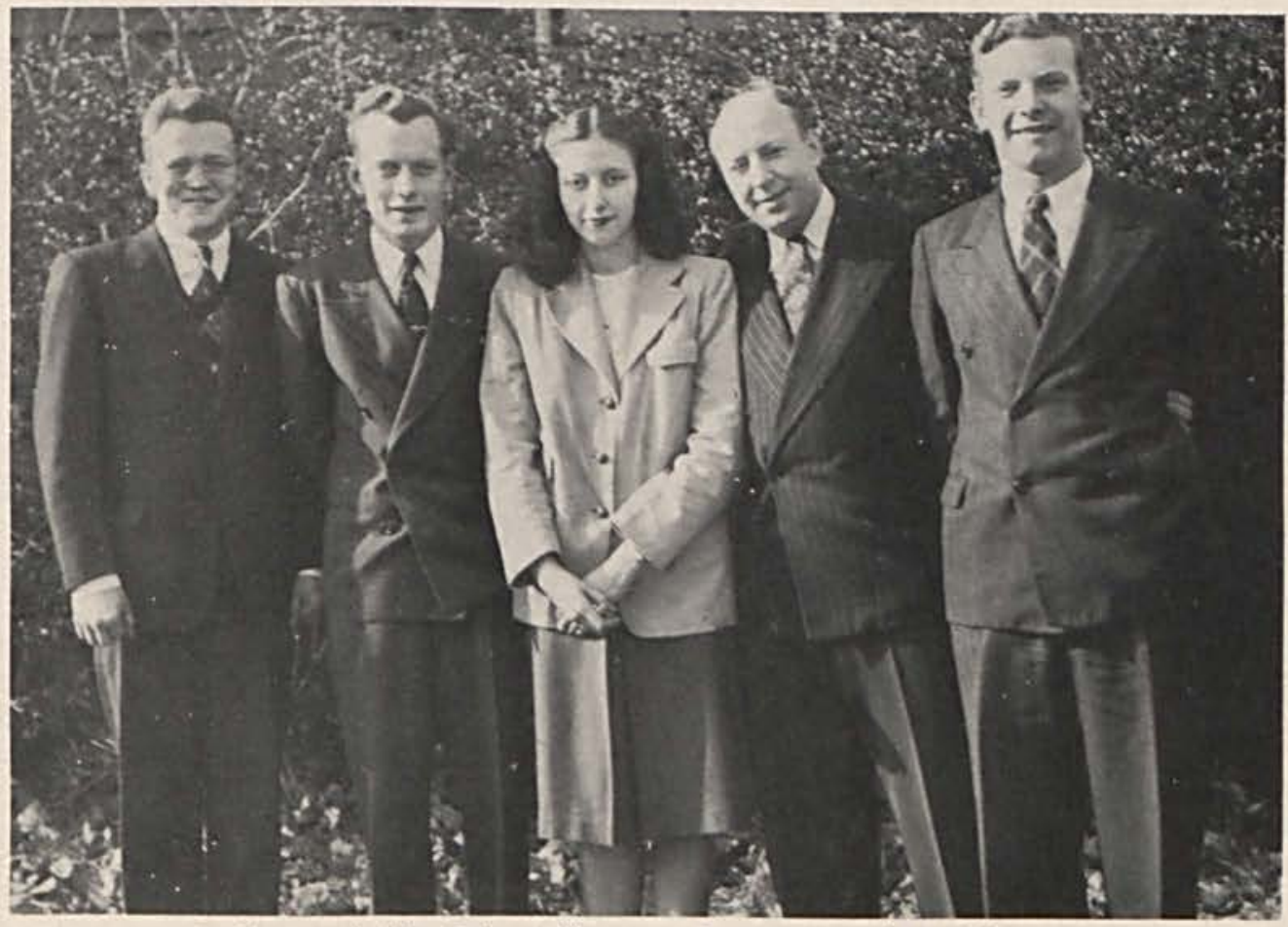

Left to right: Robert Warner, Conner Merritt, Eleanor Weismiller-pianist, Arthur Harkins, Wendell Cultice. 


\section{Young Women's Christian Association}

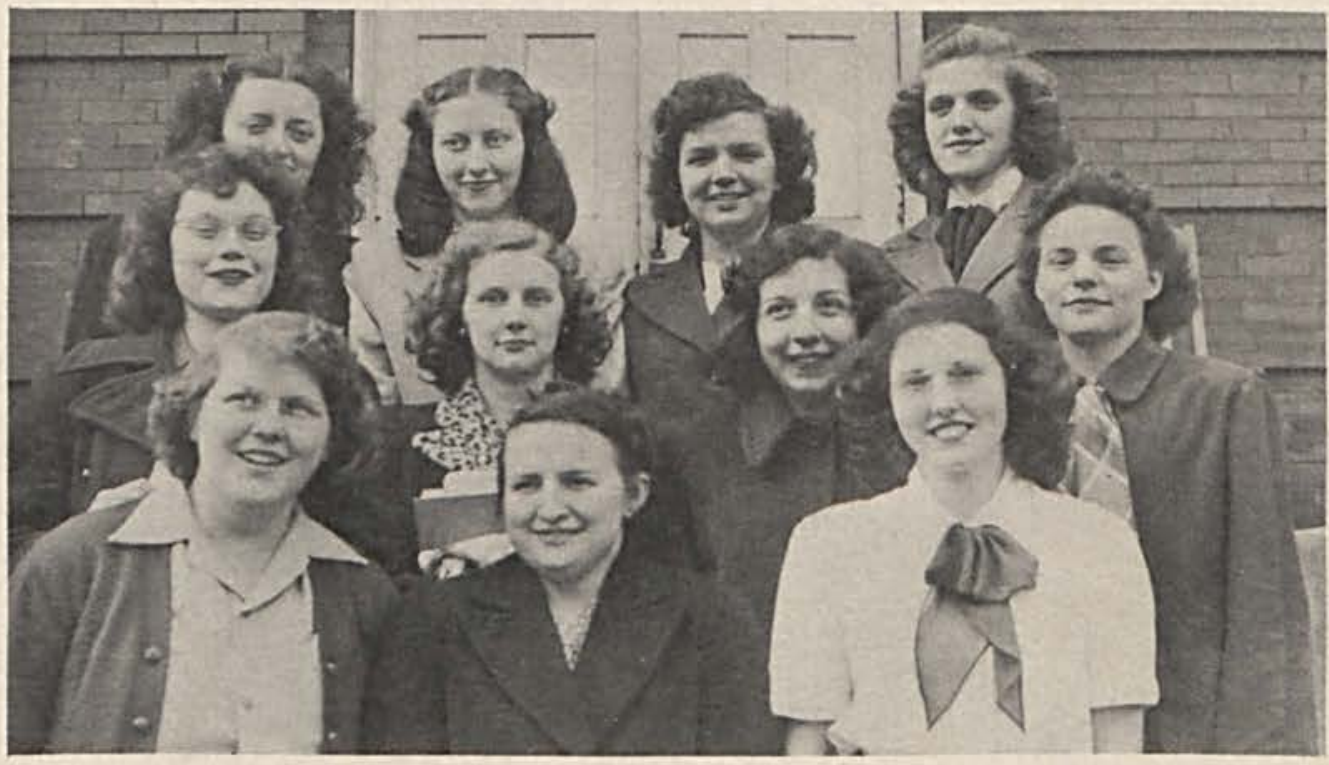

Front row: Joanna Bryant, Ruth Irvine, Martha Tannehill. Second row: Ila McLaughlin, Sally Flannery, Donna Lorton, Naomi Conner.

Third row: Charlotte Collins, Eleanor Weismiller, Kathleen Evans, Marie Fisher.

The members of the Y. W. C. A. are especially proud of their organization this school year of 1947-48 for a number of reasons. First, and very important, is the fact that the Cedarville College Y.W.C.A. became affiliated with the National Student Y. W.C.A. Through this the members have received such privileges as corresponding with foreign students, taking part in state and nationwide conferences, receiving a great variety of religious literature, and contributing to the World's Student Christian Federation.

In October, the Y. W. sponsored a candy sale in the administration building. Homemade candy was broughtfor sale by each of the girls and was purchased by the faculty and student body. On November 4 the group sponsored a Tag Day. Each individual donated some time during the day for selling the tags in the down-town district. They felt sure that their time had not been wasted when a total income of $\$ 45.50$ was reported.
The annual Committal Service was presented on November 9 in the Methodist Church with Miss Marie Fisher serving as president and leader of the devotional program.

Rings and pins were purchased by some of the members. The triangular shaped pins were of sterling silver with a fire-blue bar reading "Y. W. C. A." across the top. The triangle is the symbolic emblem of the organization. The rings were similiar in appearance.

During December the Y. W. girls were busy selling Christmas cards. On December 16 the annual Christmas party was held at Harriman Hall. The evening began with the group singing carols at different homes in the village and wasclimaxed with a gift exchange and chili supper at the dormitory. A Valentine dance was sponsored in conjunction with the Y.M.C.A. Spring activities were successful and the group is looking forward to another active year. 


\section{Young Men's Christian Association}

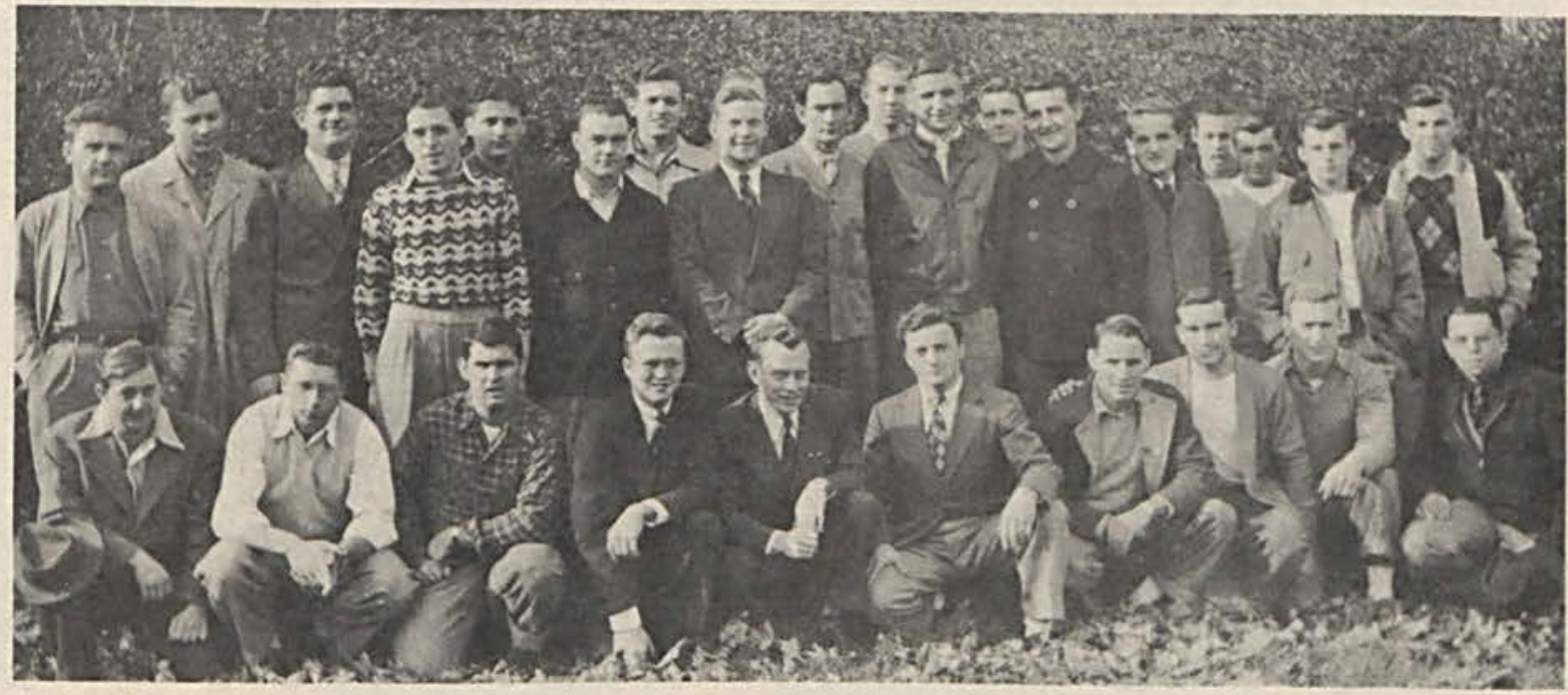

First row: John hawker, Carl Wiseman, Ray Mullen, Robert Warner, Conner Merritt, Milan Hayden, Art Lewis, William Riley, Earnest. Foster, Joe Price.

Second row: James Bradford, William Metterhouse, Kenneth Dailey, James Rowe, Louis Hrkman, Ralph Schafer, Kenneth Wilburn, Wendell Cultice, Edwin Ryan, Ray Glenn, Robert Impson, Keith Rogers, Robert Filer, Adolph Maslar, Eugene Sallie, Don Barger. Dillard Marcum, Norman Potts.

Traditionally one of the most active of Cedarville's student groups, the Y. M. C. A. returned to its former place of prominence during the school year of 1947-48. Under the sponsorship of Professor Frederick Carlson the local chapter was revived after the inactivity of the war years when there was not a sufficient number of men on the campus to continue the group.

A chapel service each semester has been presented by the Y. M. C. A. Social activities included dinners, parties, and a dance sponsored in cooperation with the Y. W. C. A. Arrangements were made to enjoy the facilities of Y. M. C. A. centers in near-by cities.

James Rowe has served as president, Conner Merritt as vice-president, Wendell Cultice, secretary; and Adolph Maslar, treasurer. 


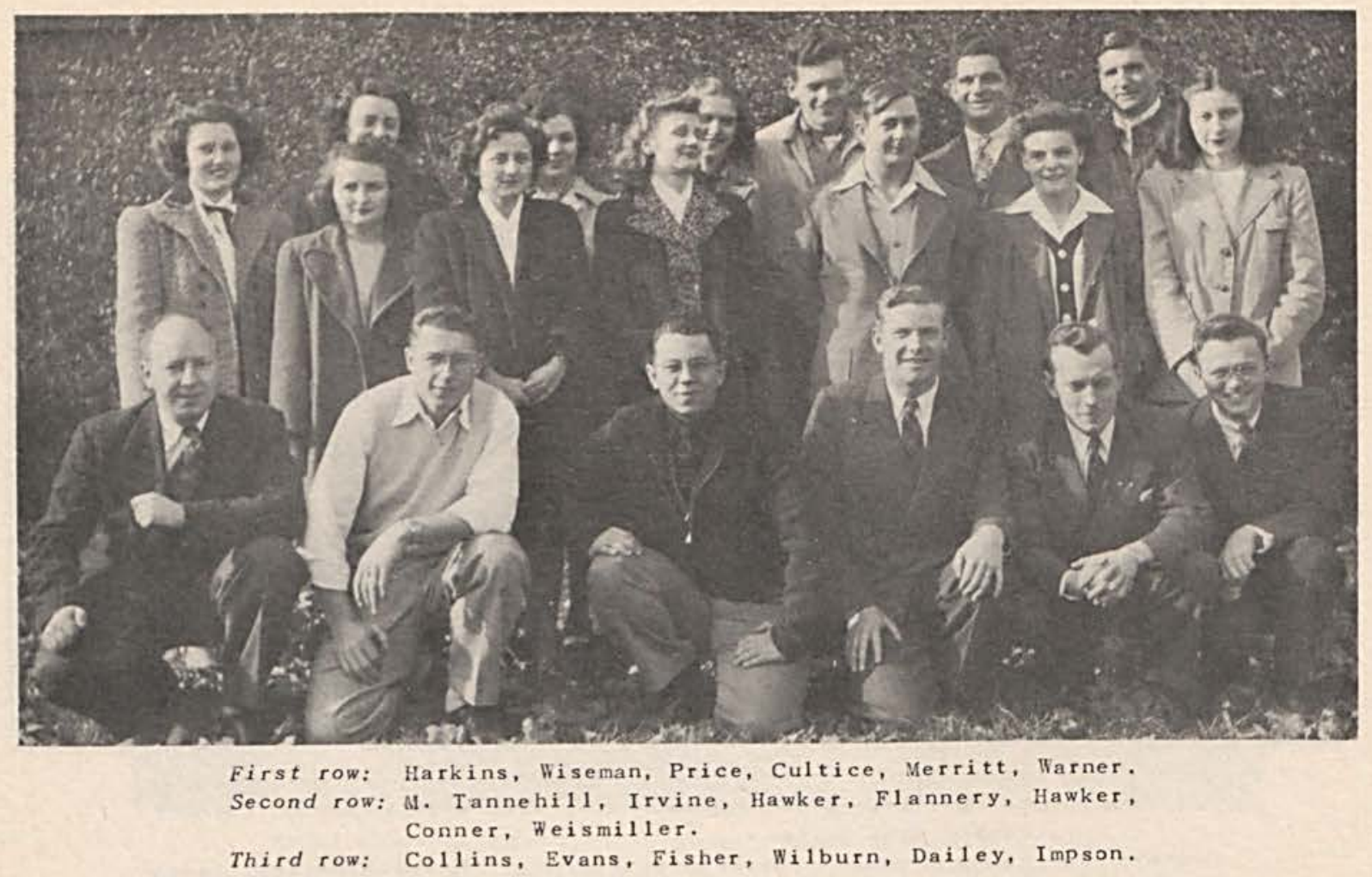

\section{Carawaners}

For years Cedarville College has maintained a group of Students known as the Gospel Team who have subscribed to the principles of Godliness both in action and in thoughts. They have demonstrated so by appearing at various churches and schools throughout the county and state. They function as a team and their program is devoted wholly to carrying the message of Jesus Christ in song and story.

When the semester of September, 1947 commenced, the nucleus for a gospel team was a meager one indeed. There were exactly four members from which to inaugurate a team. Past president Conner Merritt conducted a person-to-person program to increase the number and did not cease action until he had formed an entourage of some twenty members.

At the nextmeeting officers were elected and a new name, THE CARAVANERS. was suggested. It is not difficult to deduce reasons for such a title when one considers the caravans of old. In those days, great ensembles of camels and drivers treked across the deserts of Arabia and Egypt bearing the priceless gifts, incense, myrrh, and rare metals of merchants and kings. Today the Caravan of Cedarville College treks across highways and crossroads bearing the Word of Jesus Christ to all who will listen. The Son of Godis very often the only ray of hope to which a tired and bewildered people may turn. The Caravan carries this ray of light and in so doing feels a sense of gratitude for the opportunity.

There are no outstanding members of the Caravan. Each person contributes his share. Someone reads a portion of the Scriptures, another sings a hymnal solo, still another reads a religious poem, another leads the group in prayer. Always one of the Caravan prepares a brief message which enhances the milieu of those attending the program. 


\section{Future Teachers of America}

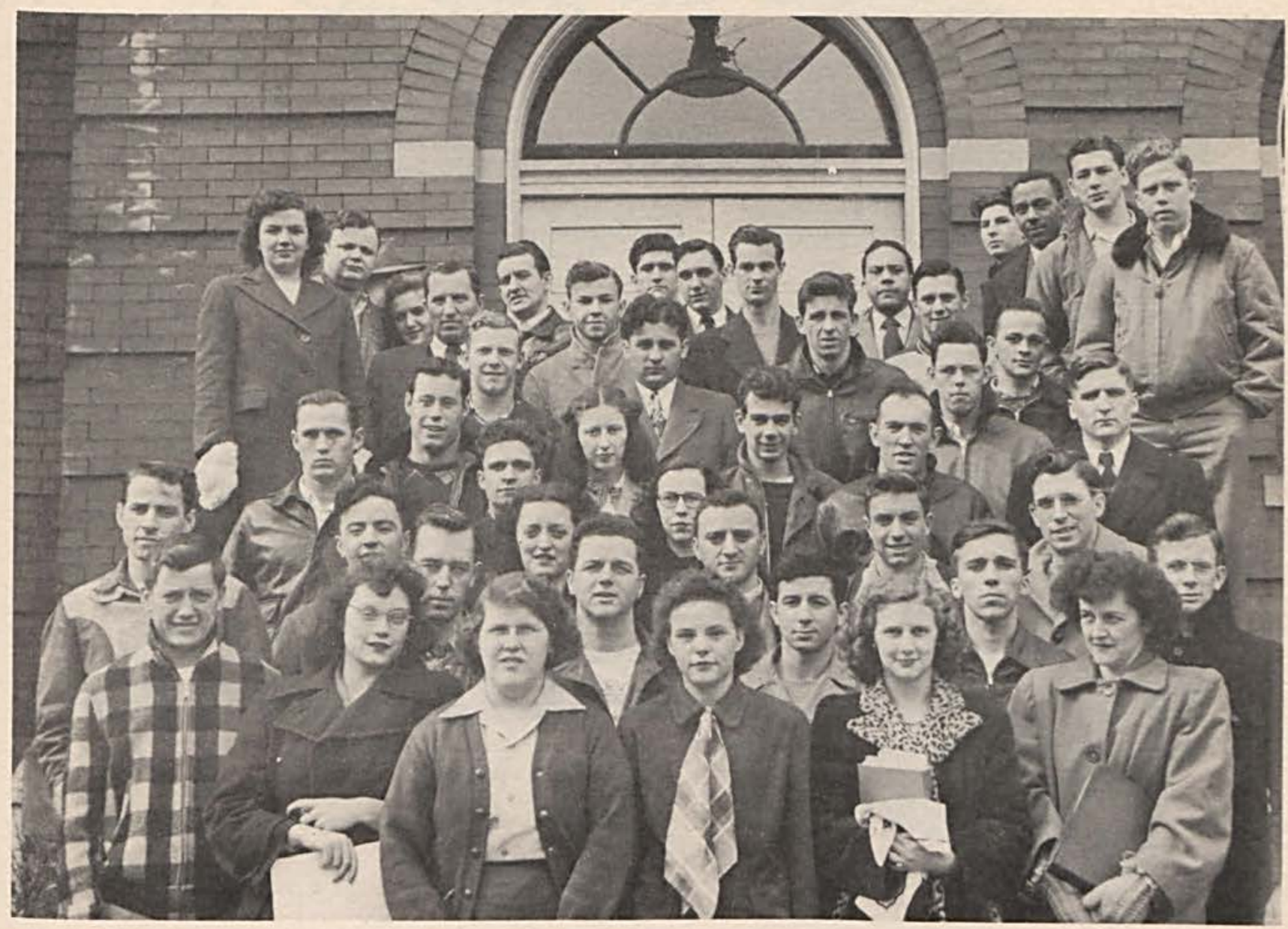

First row: J. Bryant, Conner, Flannery, Rinehart.

Second row: Barger, McLaughlin, Huffman, Barton, Bitler, Dunn, Osman.

Third row: A. Lewis, J. Lewis, Collins, McGuinn, Hayden, Wi secup, Rowe.

Fourth row: Ross, Sallie, Sisson, Weismiller,

Fifth Loos, Judy, Ulsh, Impson, Nock.

Cultice, Hrkman, Townsley, Lipp, Sewak.

Sixth row: Evans, Beattie, Potts, Rader, Clark, Dunlap, Brown.

Seventh row: Strick, Harkins, Fisher, Filer, Wat kins, Gutzwiller, Skillings.
The A. J. Hostetler chapter of the F. T. A. was formally organized February 11, 1948. The Cedarville chapter was named for the late Professor Hostetler, director of the department of education, whose ability and skill remain an inspiration to future teachers.

During the period of organizing the group much interest was aroused and fifty students from the education department became members. It is expected that all future teachers will join the chapter and gain its benefits.

Meetings are held once each month with an interesting and educational program. Well known speakers and educators are invited. Interest in teaching is maintained by reading and discussing articles in periodicals each member receives.

Professor Beattie, who encouraged the formation of the local chapter, is faculty advisor for the group. Officers are: Rollie Barton, president; Conner Merritt, vice-president; Kathleen Evans, secretary; Marie Fisher, treasurer; Robert Impson, librarian; William Troute, historian; Kenneth Huffman, parliamentarian; Eleanor Weismiller, song leader.

R. B. 


\section{Chi Mu Delta}

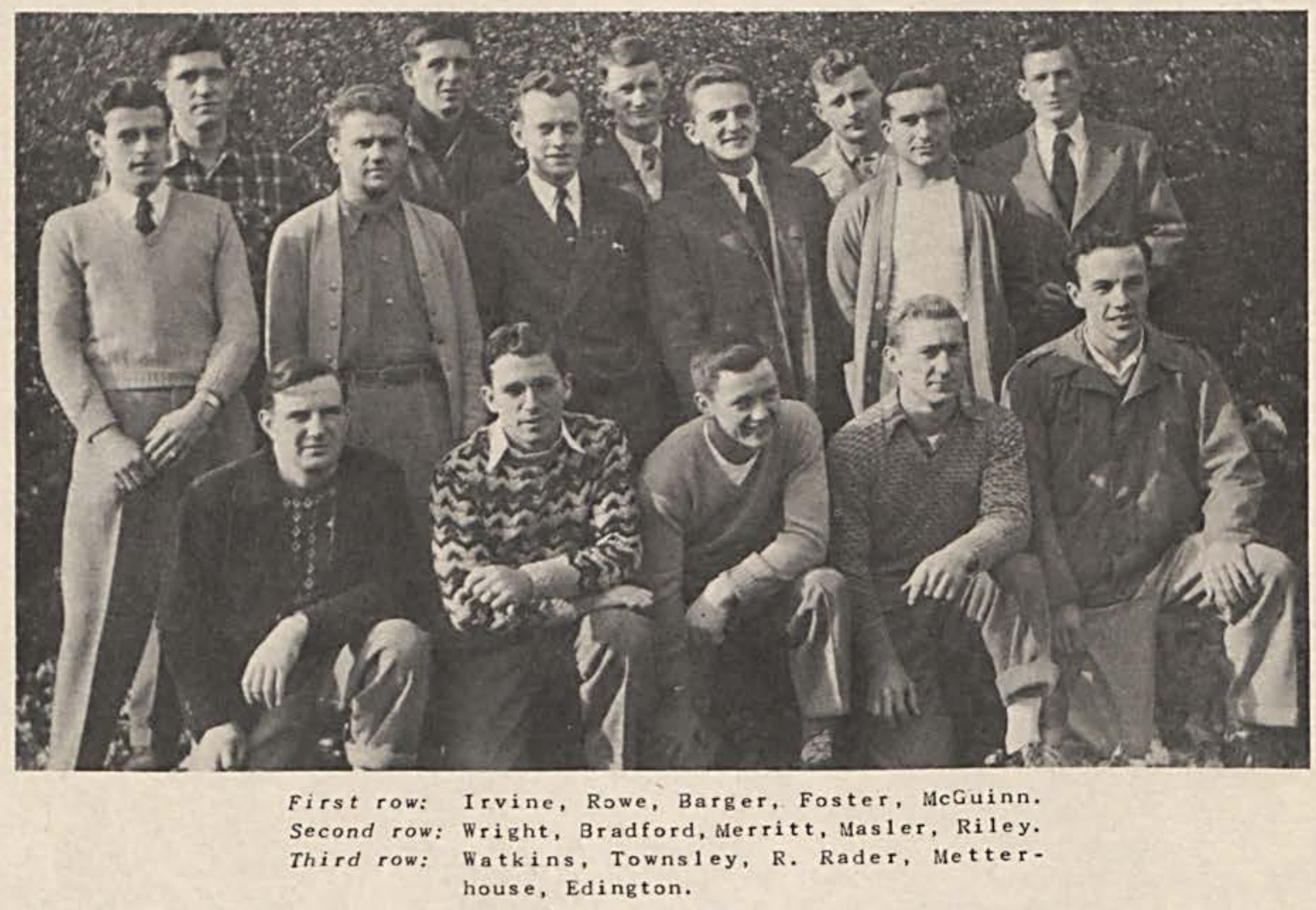

The Chi Mu Delta Fraternity is in one of its most prosperous and active years at Cedarville College. Officers were elected at the beginning of the school year and plans were made for the pledging of new members shortly thereafter. After a pledge period six new brothers were officially sworn in at a fete held in their honor at the Old Mill Camp on November 3 .

A Halloween party was the first social event provided by the fraternity for the entertainment of the entire student body. Dancing and cake walks were enjoyed and a new, popular recreation was introduced in the "Hit Little Ernie" game with Earnest Foster as the target.

An effort was made to establish contact with fraternity members who have graduated and left Cedarville. To continue the relationshipafter school days, the fraternity initiated plans for purchasing or erecting a house. The house will provide a rooming place for members in school and a meeting place for alumni who return to see the progress made by the fraternity and Cedarville College 


\section{Chi Sigma Phi}

The Chi Sigma Phi sorority, only sorority on the campus at present, was organized in 1935. The sorority holds several social activities during the year. One of the most important of these is the pledge party. Girls are pledged each semester. Once a year the sorority sponsors a dance for the entire student body.

At the beginning of the second semester Donna Watkins resigned as president and was succeeded by Kathleen Evans. Helen Tannehill is vice-president; Ellen Hawker, secretary-treasurer, and Patty Grieve, news reporter.
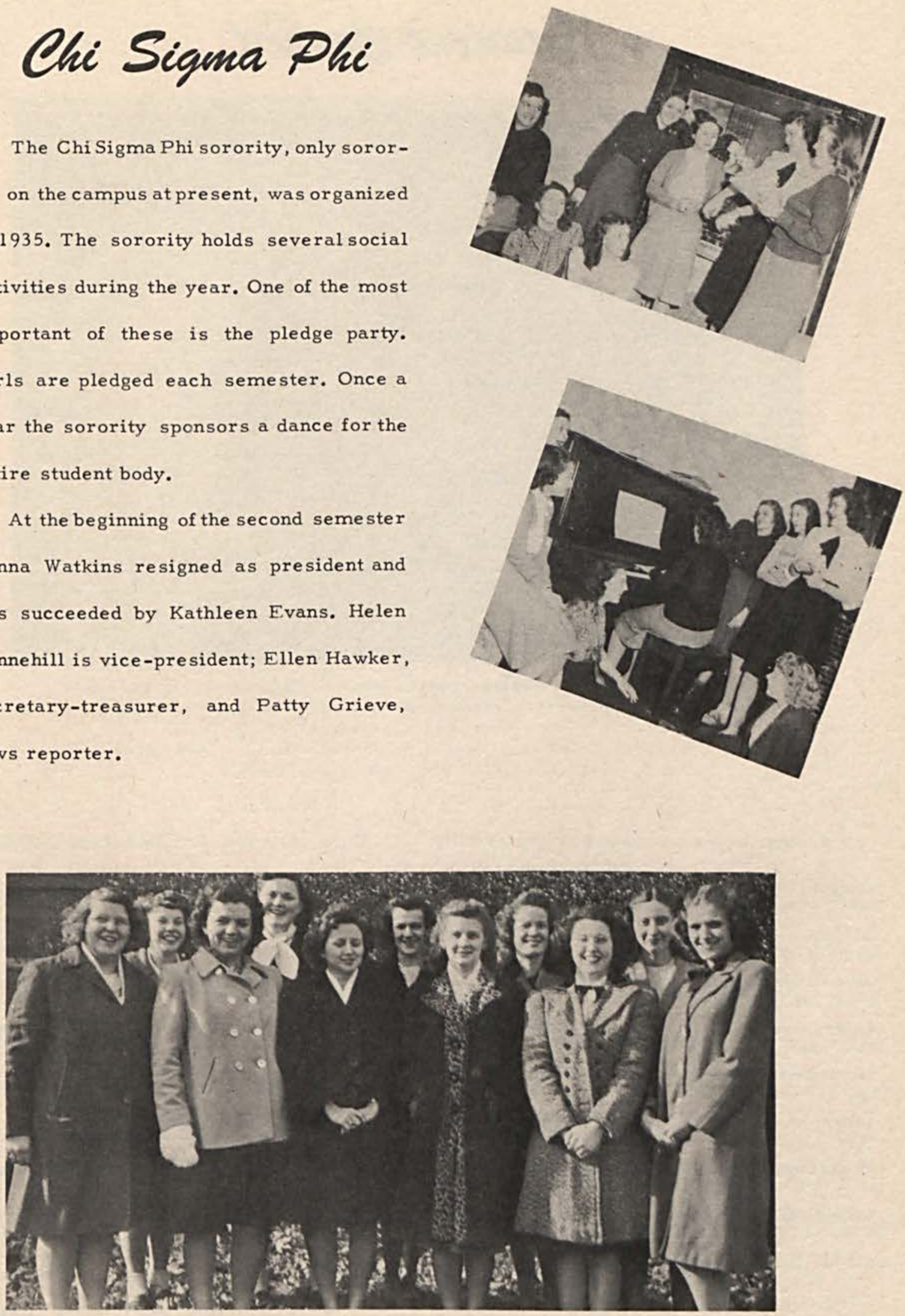

J. Bryant, H. Tannehil1, Evans, Grieve, Hawker, Knecht, F1annery, Watkins, M. Tannehil1, Weismi11er, Fisher. 


\section{Student Council}

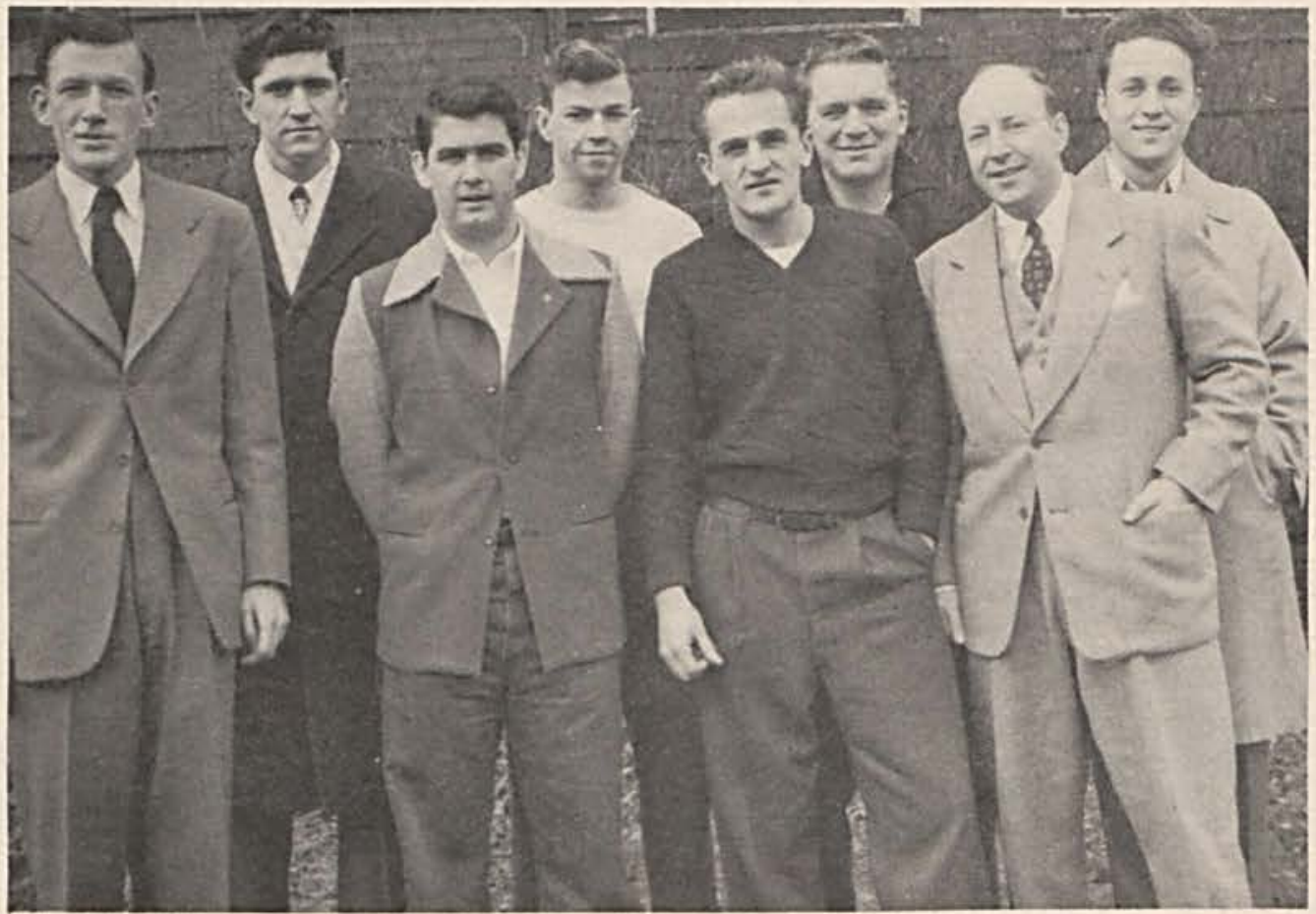

Edington, Watkins, Mullen, Potts, Maslar, Rudy, Harkins, Kennedy. Not pictured:. Preston, Sheley, Troute.

Another organization to resume activity during the school year of $1947-48$ is the Student Council. Each class elected representatives to the Council in September, officers were picked, and plans for the annual Homecoming were begun. A parade, presentation of the queen and attendants at the Homecoming football game, and a semiformal dance were sponsored by the Council for the day's program.

To determine the functions of typical student government groups, a survey was made of the work done by them in other
Ohio colleges. One new responsibility accepted by the Cedarville College Council was to sponsor each Monday's assembly. A committee prepared a calendar of programs to be presented by the student organizations and the plan was followed successfully. The Student Council was also instrumental in reviving the Cedrus by polling the student body for prospective purchasers.

Carl Watkins served as president, William Troute as vice-president, and Margaret Sheley as secretary-treasurer. 


\section{Pennsyluanians}

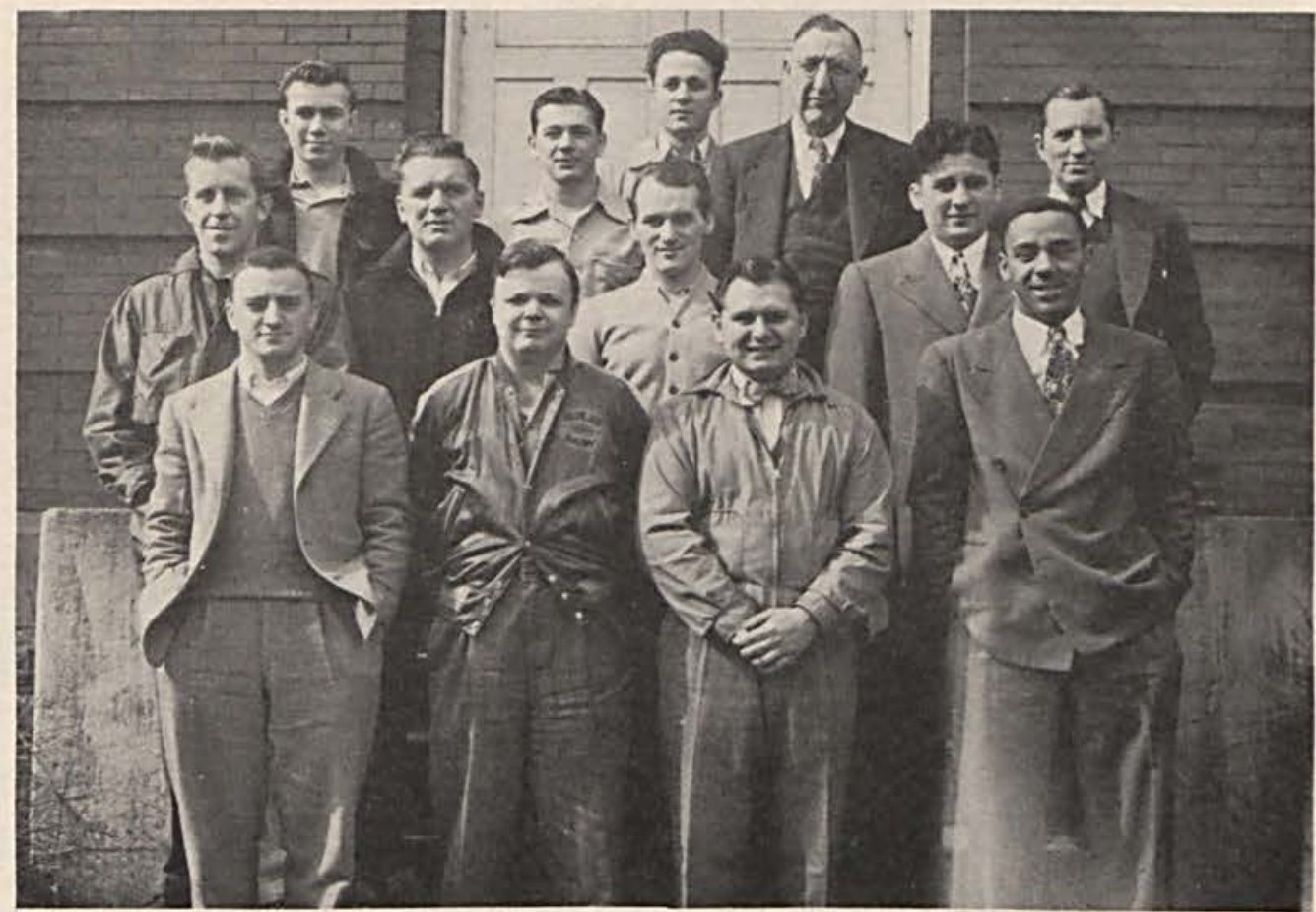

Front row: Hayden, Johnstown; Strick, Johnstown; Machamer, Lewistown; Brown, Harrisburg.

Second row: Gross, Lewistown; Rudy, Lewistown; King, Carlisle; Hrkman, Johnstown.

Third row: Stoehr, Pittsburg; Sewak, Johnstown; Kennedy, Lewistown; Jurkat, New Galilee; Beattie, Sharon.

Thirteen Pennsylvanians attending Cedarville College met during the second semester of the school year to form a new campus organization, the Pennsylvania Fraternity. One of the main objectives of the group is to help new students from Pennsylvania adapt themselves to college life. Meetings are scheduled twice each month. The state's insignia, a keystone, has been selected as an emblem for fraternity pins.

Professor Jurkat was elected faculty advisor, Professor Beattie, an honorary member, and Harold Machamer, president of the group. Other officers are: Lou Hrkman, vice-president; Park King, secretarytreasurer; Dick Brown, chaplain; Bob Kitting, sgt. at arms; and Jay Check, publicity agent. 


\section{The Cedrus Staff}

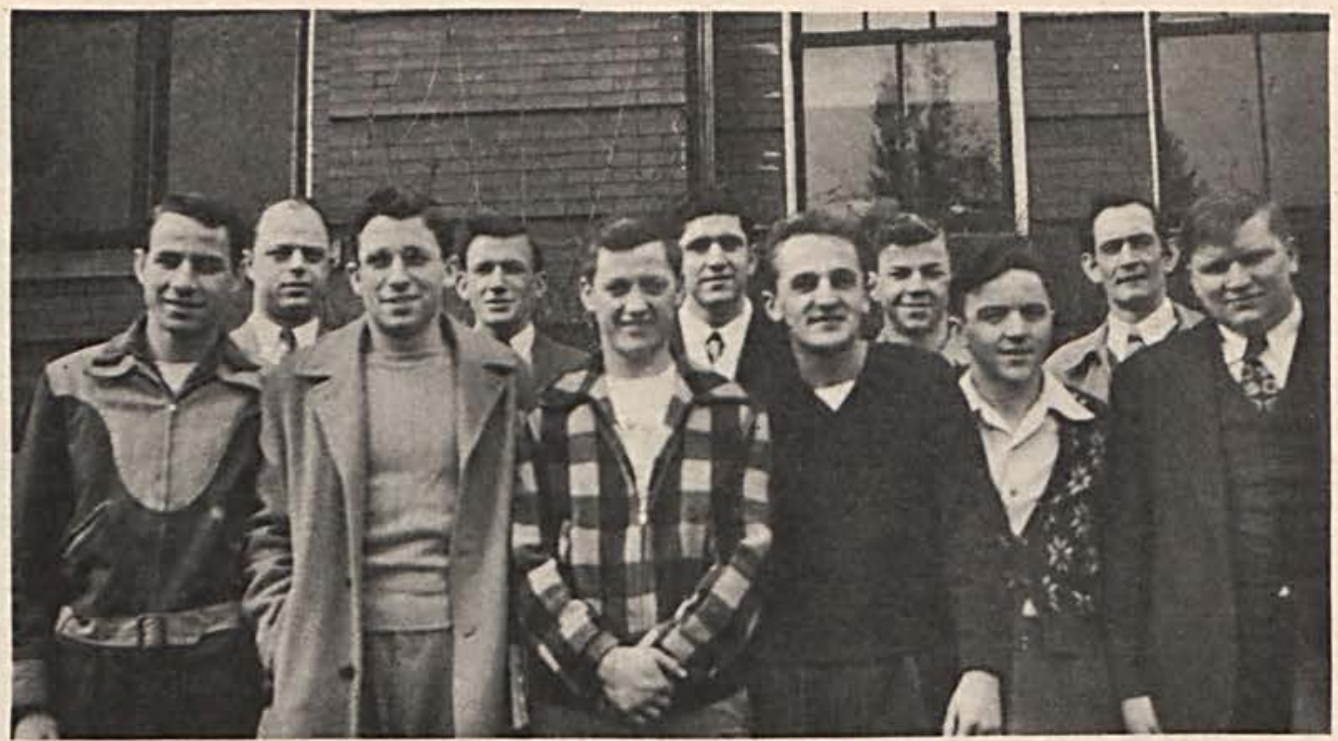

The ' 48 Cedrus marks the return of Cedarville's annual review after an absence of six years. Although past editions were consulted, the staff attempted to modernize the book and produce one "new and different." Every step was carefully considered in the light of journalistic value, entertainment merit, and economic advantage. It is the sincere desire of all those who have worked on this annual that it shall be a storehouse of memories to be appreciated in the future.

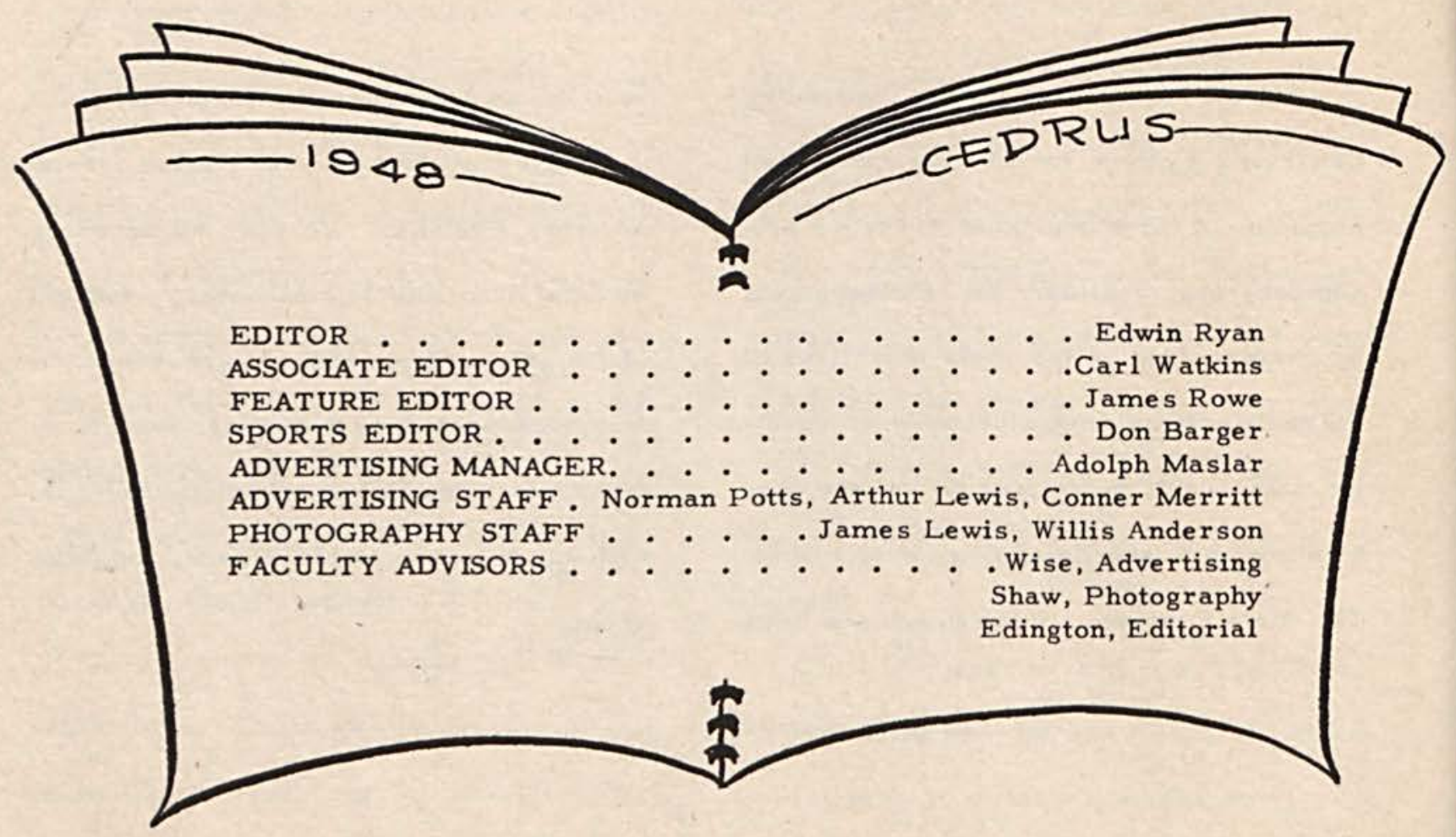



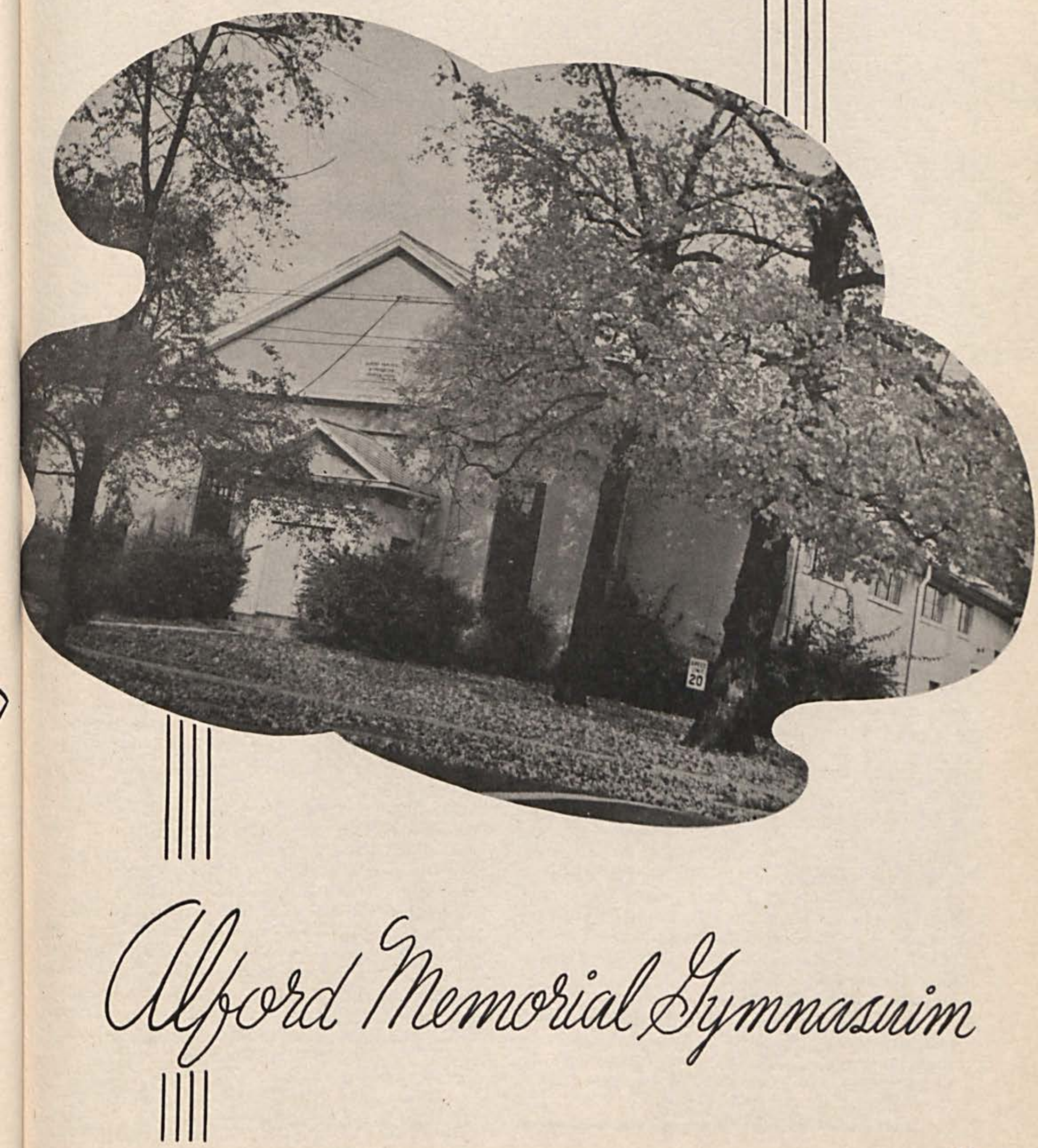



\section{YELLOW JACKETS}

FOOTBALL SCHEDULE

Sept. 16-Ohio Northern -...........- Home Sent. 23-Georgetown ............. Home Sept. $30-$ Ashland Home

Oct. 9-Bluffton _..._..._....... A way Oct. 16-Detroit Tech (Homecoming) Home Oct. 22-Morehead State

Oct. 30-Wilmington Away

Nor. 6-Rose Poly Away

During 1947 the training room was enlarged and equipped in line with the general improvements of the Physical Education Department.
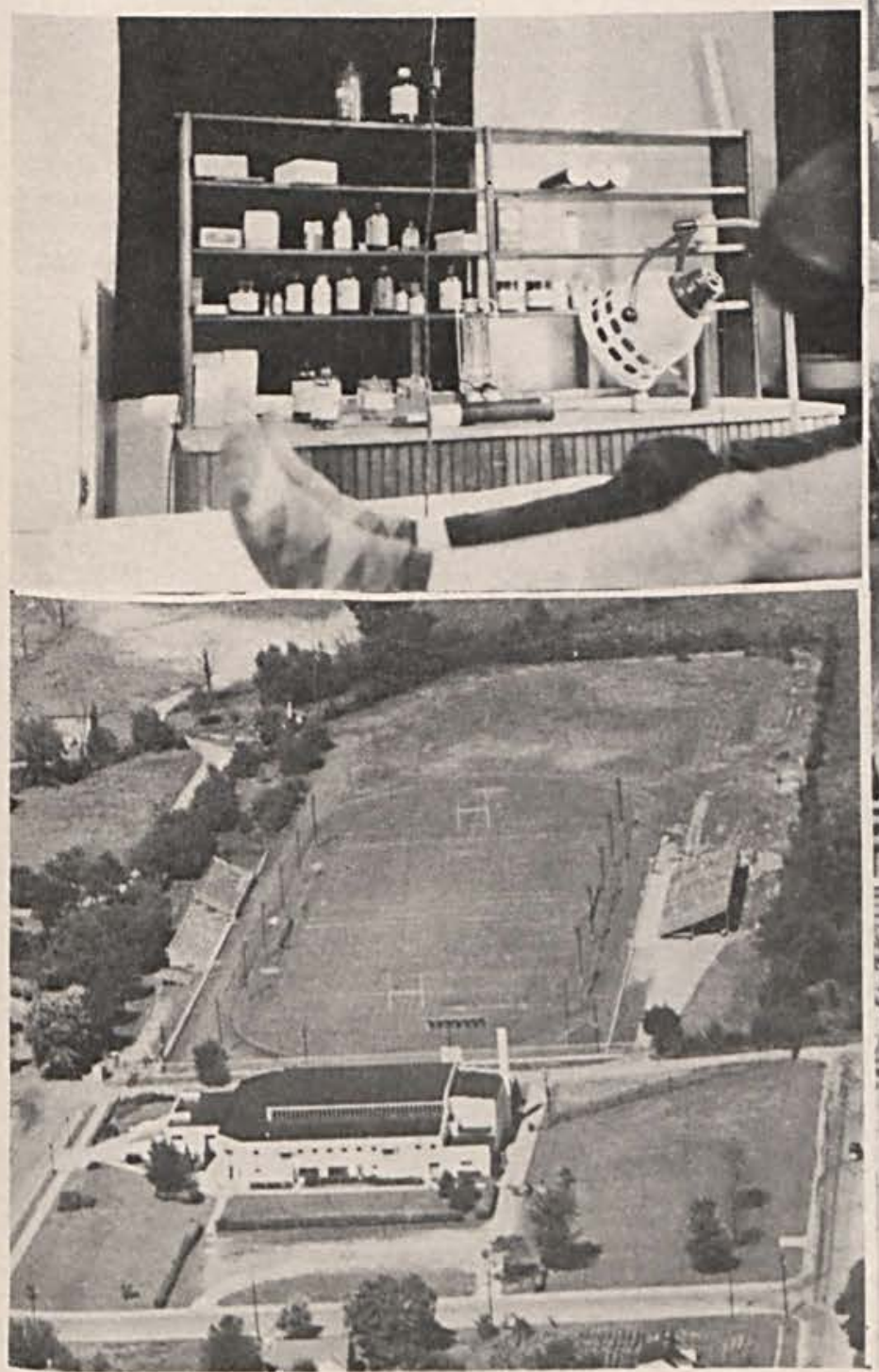
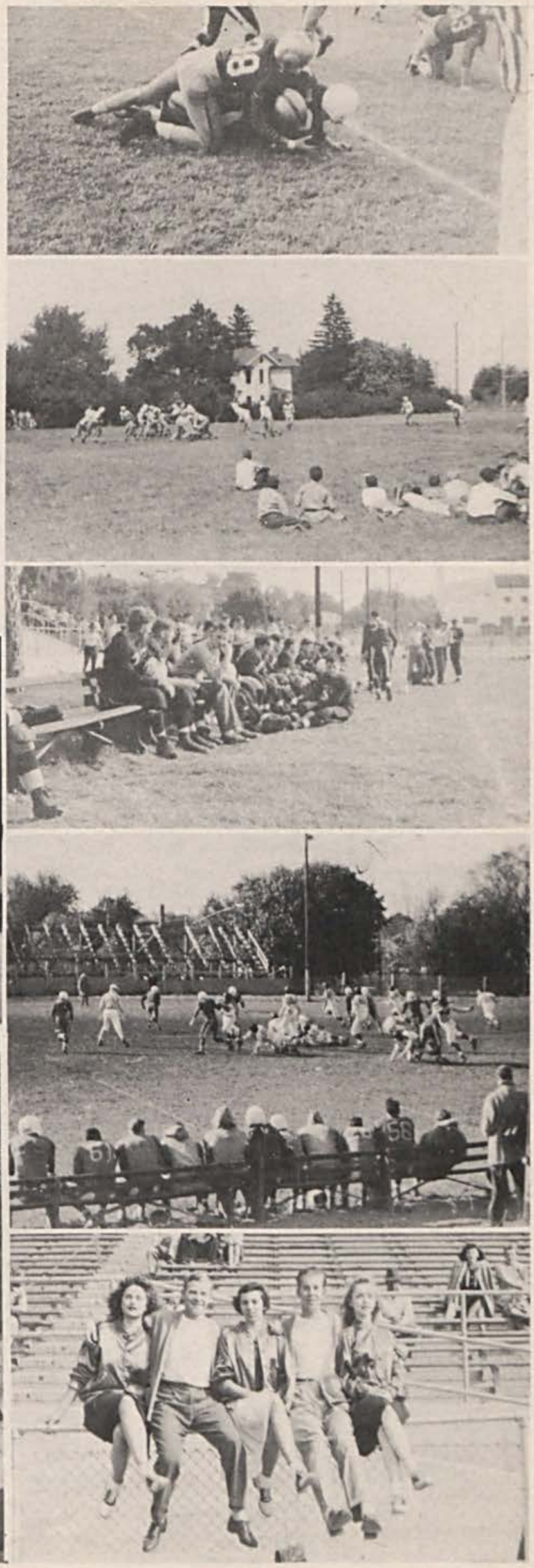


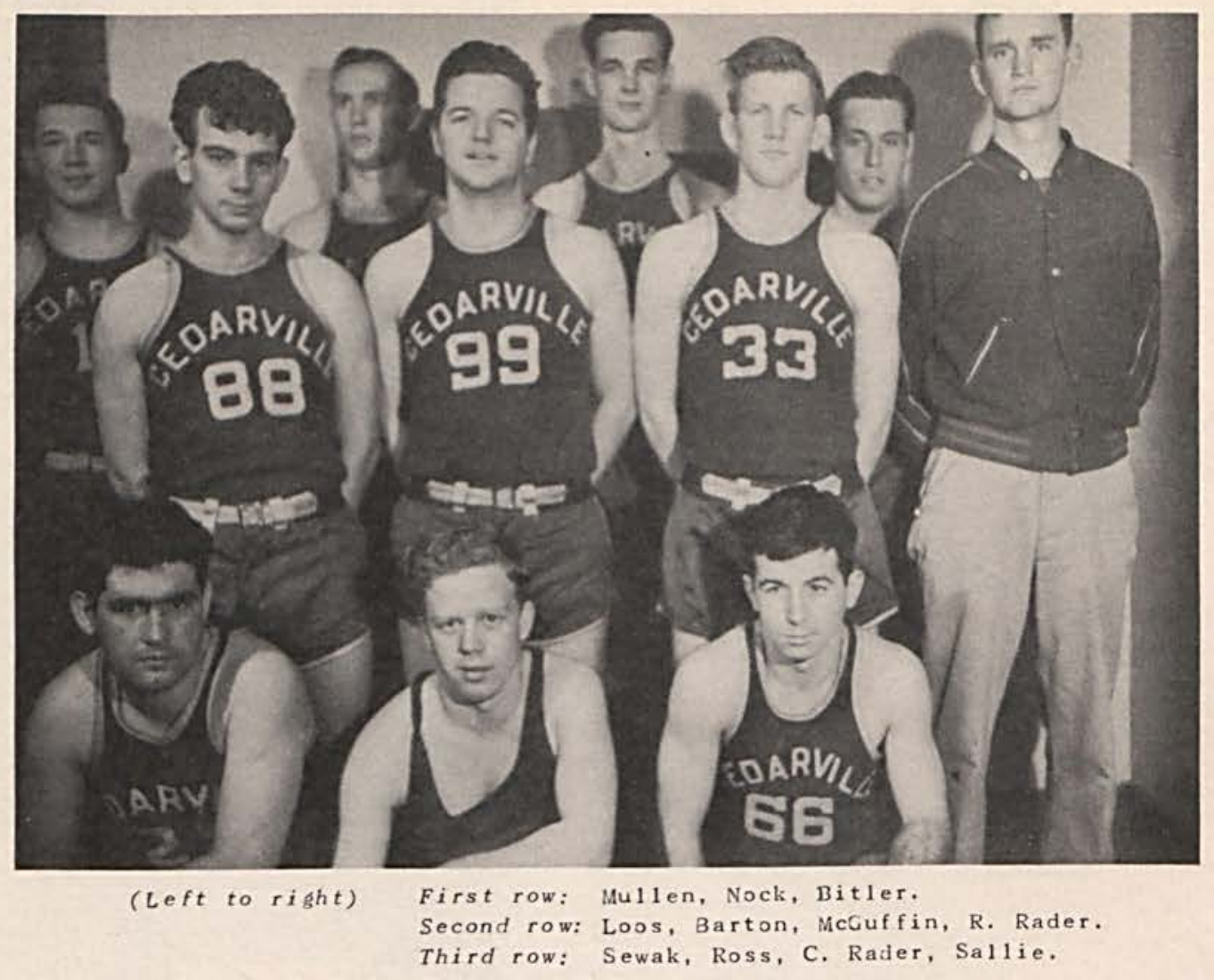

\section{Gunior Varsity}

The Junior Varsity completed a successful season that included a victory over one rival, Urbana Junior College. The Wilmington $\mathrm{J}-\mathrm{V}$ 's another traditional foe gained revenge for their defeat last season. Most of the junior varsity games were played as preliminaries

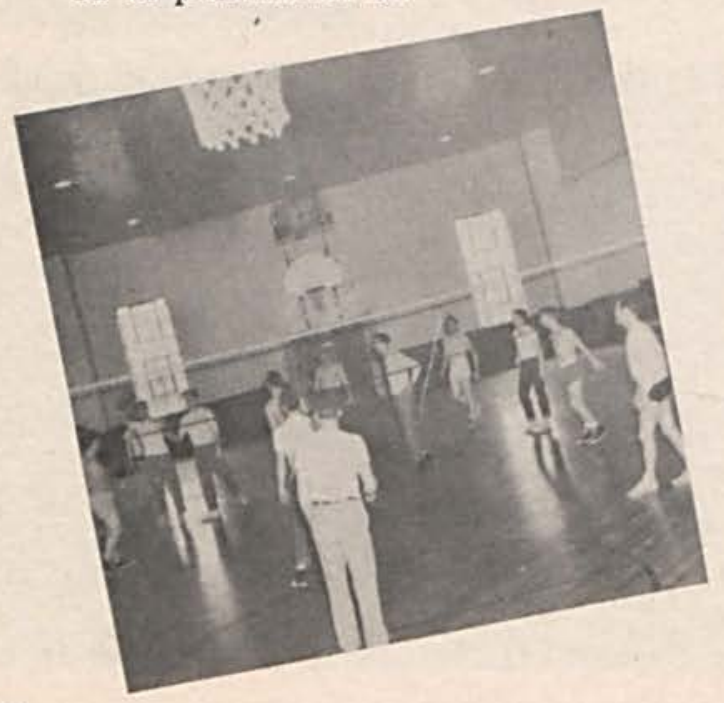

Basketball is one of the many activities encouraged in the physical education department. Seen at left, below, is a typical physical education class in Alford Memorial gymnasium. Right, below is the Junior Varsity in action.

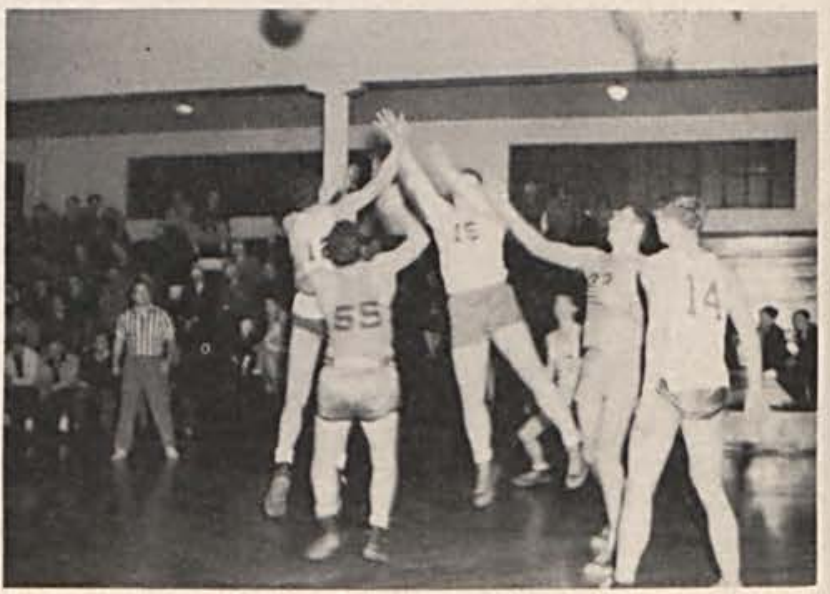




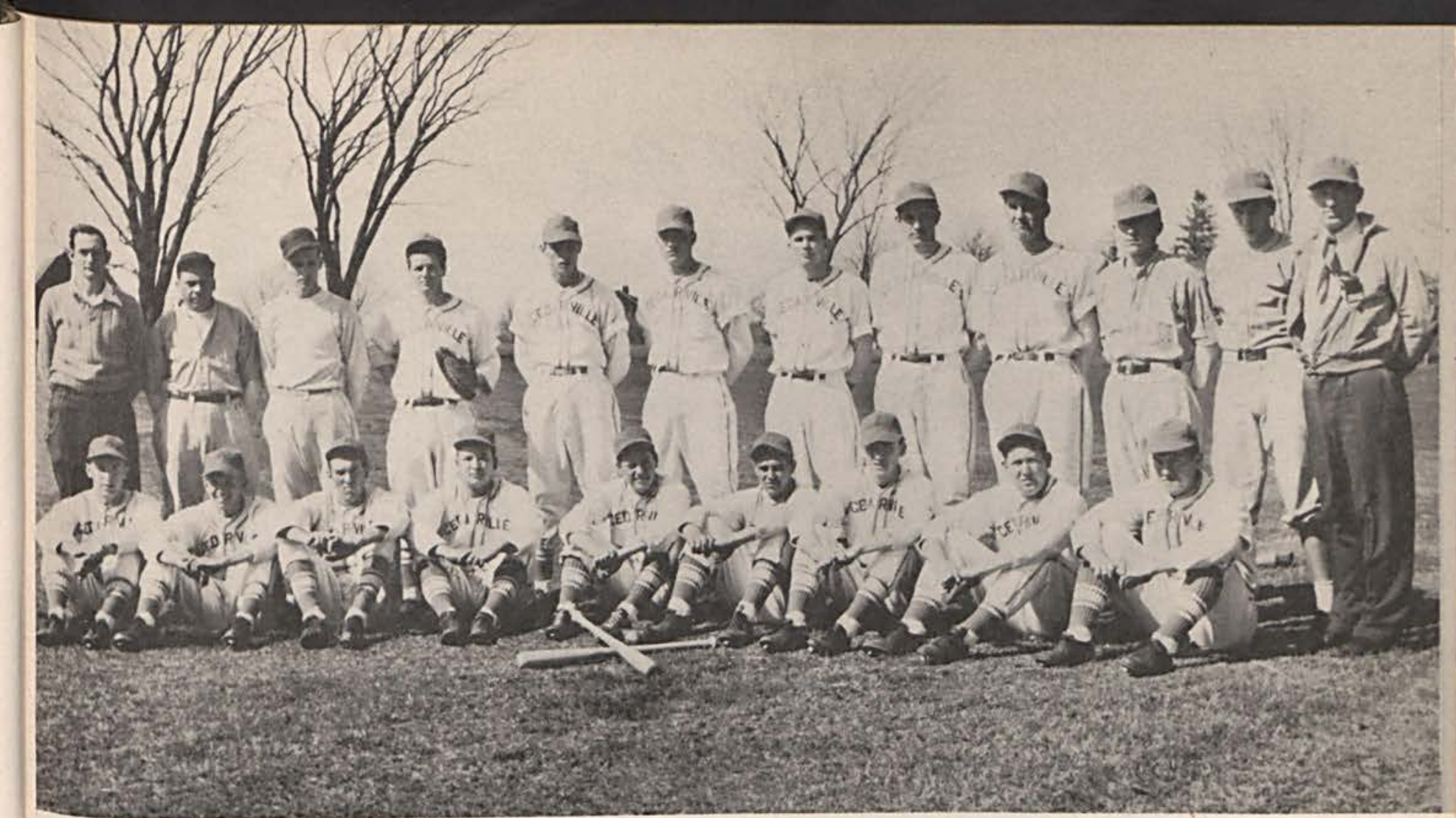

(Left to right)

Second row: Ryan, Mgr.; Clark, French, Barton, Huffman, M. Townsley, Judy, Jewe11,

Barger, Dunlap, Troute, Farmer, B. McNulty.

\section{Baseball} Shaughnessy, Brewer, Braley, Wat kins, V. McNulty, Weimer, McNeal, Coach Beattie.

Baseball ranks as a major sport at Cedarville College. During the early season in-door work-outs in the gymnasium helped to get the players in shape for the season.

The 47 record was five wins in eight games. The $5-1$ victory over Xavier University with Marcus Townsley on the mound was one of the season highlights. Townsley also threw a one hitter against Findlay in the opener. With the climax of the season, Virgil "Birdie" McNulty closed his illustrious athletic career at Cedarville.

Baseball Scores

$\begin{array}{lrlr}\text { Cedarville } & 4 & \text { Findlay } & 1 \\ \text { Cedarville } & 13 & \text { Wilberforce Univ. } & 4 \\ \text { Cedarville } & 19 & \text { Wilberforce Univ. } & 6 \\ \text { Cedarville } & 8 & \text { Bluffton } & 5 \\ \text { Cedarville } & 5 & \text { Xavier } & 1 \\ \text { Cedarville } & 5 & \text { Findlay } & 6 \\ \text { Cedarville } & 8 & \text { Xavier } & 12 \\ \text { Cedarville } & 3 & \text { Ohio State "B" } & 6\end{array}$

Cedarville 3 Ohio State "B" 6

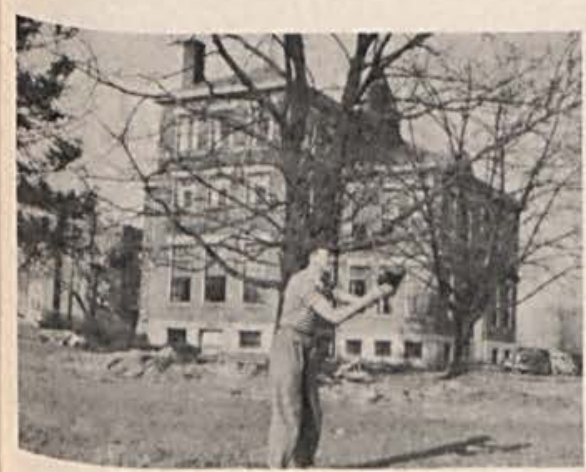

Baseball Schedule 1948

April 9 At Marshall

April 10 Villa Madonna

April 15 At Wilmington

April 17 Findlay

April 20 Xavier

April 24 At Dayton

April 26 Wilberforce State

April 30 At Villa Madonna

May 4 At Xavier

May 7 Marshall

May 10 Bluffton

May 11 Dayton

May 20 At Wilberforce State

May 21 Wilmington

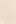
5

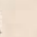

6 12 


\section{The" C"Club}

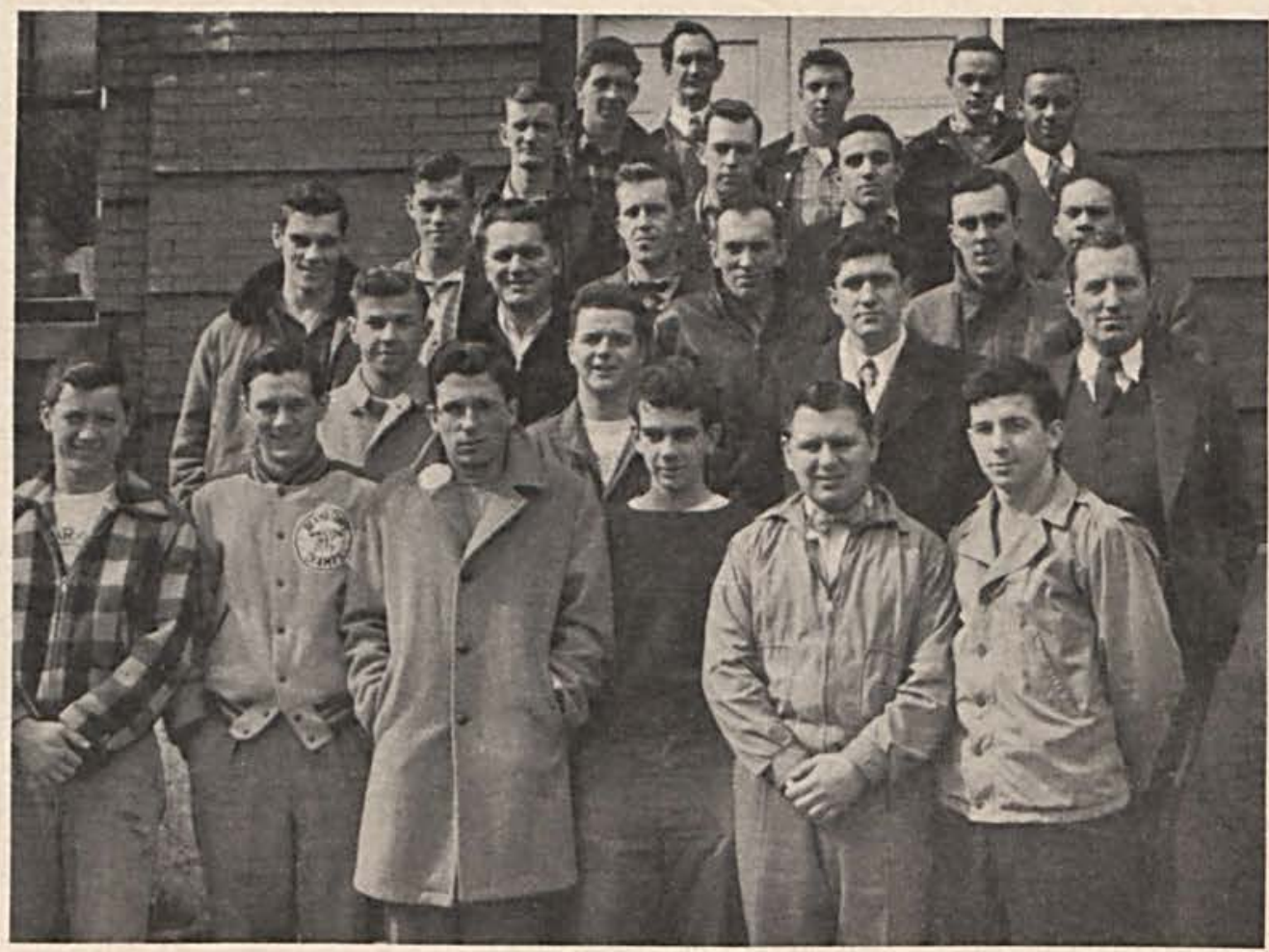

(Left to $r i g h t$ )

First row: Barger, Dunlap, Rowe, Loos, Machamer, Bitler.

Second row: Potts, Barton, Watkins, Coach Beattie. Third row: Stanley, Rudy, Judy, Moler.

Fourth row: MeNulty, Gross, Huffman, Cultice, Clark.

Fifth row: Rader, Townsley, Ryan, Wisecup, 3rown.

The "C" Club is a newly formed club on the campus this year. The " $C$ " Club is composed entirely of athletes who have earned a letter for their excellent achievements in sports at Cedarville College in Football, Bas- ketball, Baseball, Track or Tennis. The purpose of the organization is to promote sportsmanship in college, to create an interest in intercollegiate athletics and to foster the desire to merit a "C".

Two new sports this year, in which varsity " $C$ " may be earned, are: Track and Tennis.

\section{Track}

$\begin{array}{lrl}\text { April } & 17 & \text { Marshall } \\ \text { May } & 1 & \text { Xavier } \\ \text { May } & 6 & \text { Dayton } \\ \text { May } & 15 & \text { Marshall }\end{array}$

Here

Here

There

There
Tennis

Wilmington

Marshall

Marshall

Wilmington
There

Here

There

Here 


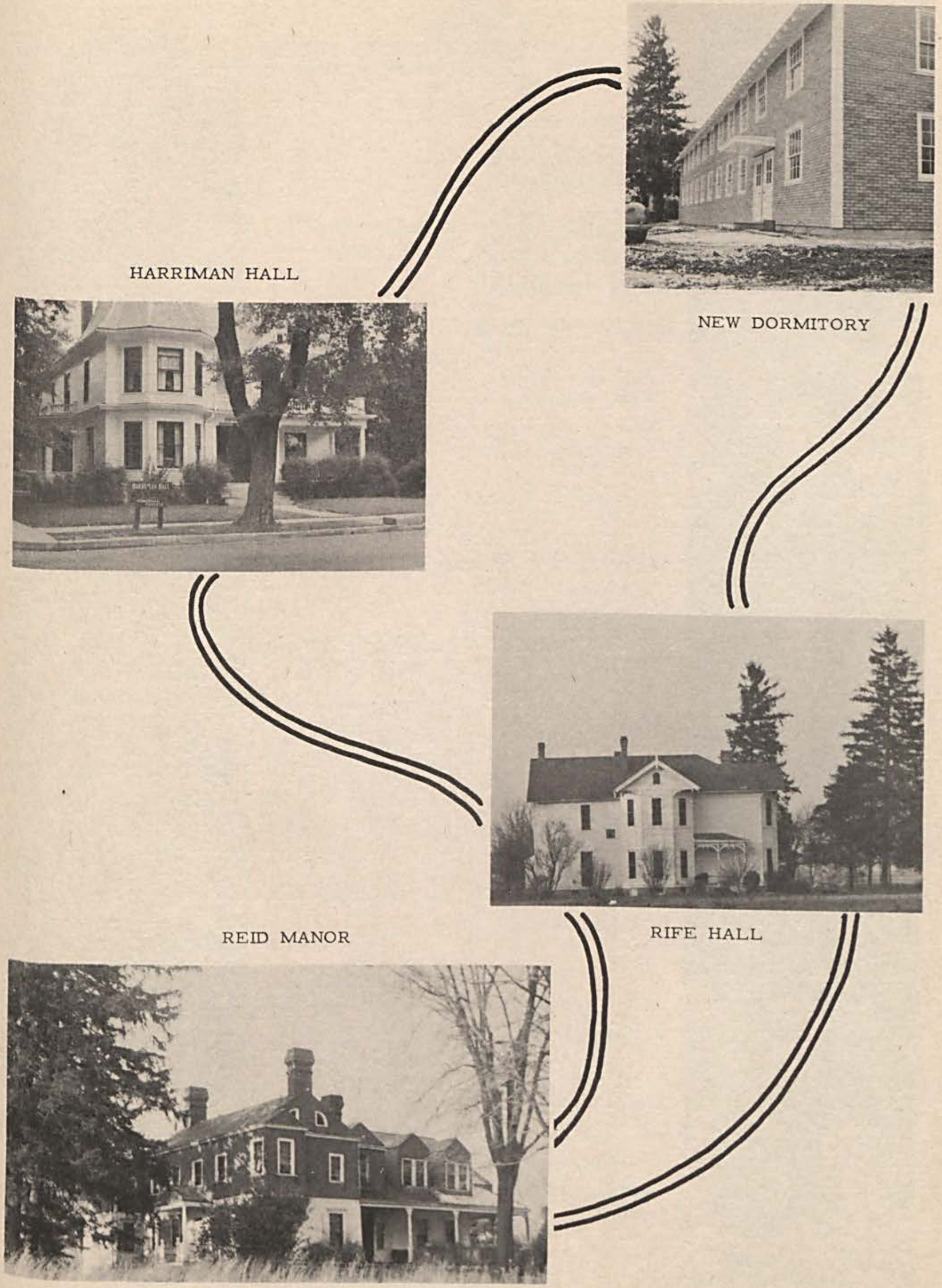


Seniars
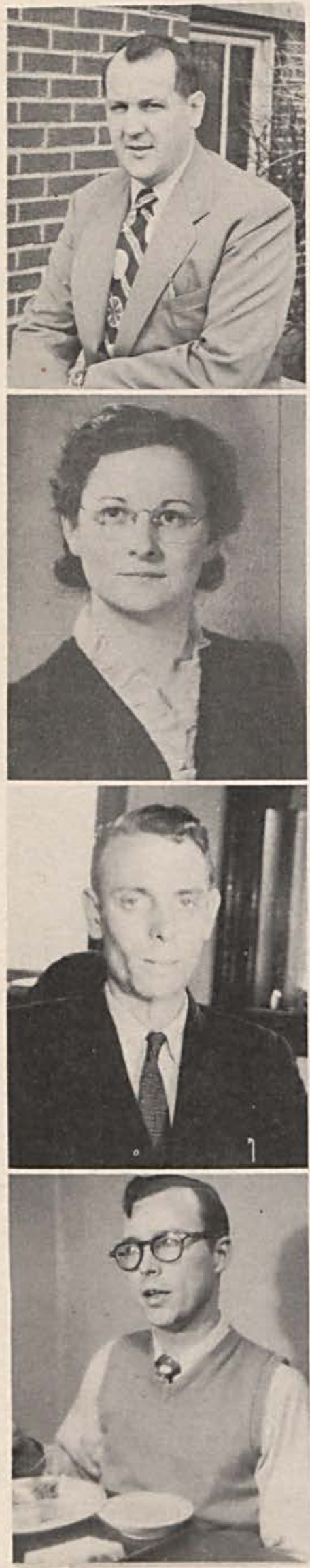

ELLEN SMITH HAWKER

Cedarville, Ohio

\section{WILLIS ANDERSON \\ Xenia, Ohio}

Kent State University

1, 2, 3; Footbal1 1,2; Swim-

ming Team 1, 2,3; Univer -

sity Theatre Group 2, 3;

University Pubilications

2, 3; Men's Union 1,2,3;

Kappa Mu Kappa Fraternity

2,3 .

Cedarville College 4: Footbal1 4; "C".Club 4 ;

MARY JANE CAVENDER Bradford, Ohio

FREDERICK HUISH Jamestown, Ohio

CLARENCE JEWELL Hamden, Ohio

Rio Grande College 1,2; Basketbs11 2. Footbal1 2; Basebal1 2 ; Dramatics 2 . " R" Association 2; Cardina 1 Staff 2; Veterans Organization 2 .

Cedarville College 3,4 ; Footba11 3,4 (Captain-

WESLEY DUTIEL Rio Grande, Ohio 4 . 4 . De 1 ta Fraternity 3,4 ; .. C."Club 4; Dramatics 3,4 .

Rio Grande College 1, 2, 3; Ministerial Club $1,2,3$ Veterans Club 1, 2, 3 .

Cedarville College 4: F. T. A. 4.

JOHN KRUMM Springfield, Ohio

GEORGE LIPP

Cincinnati, Ohio

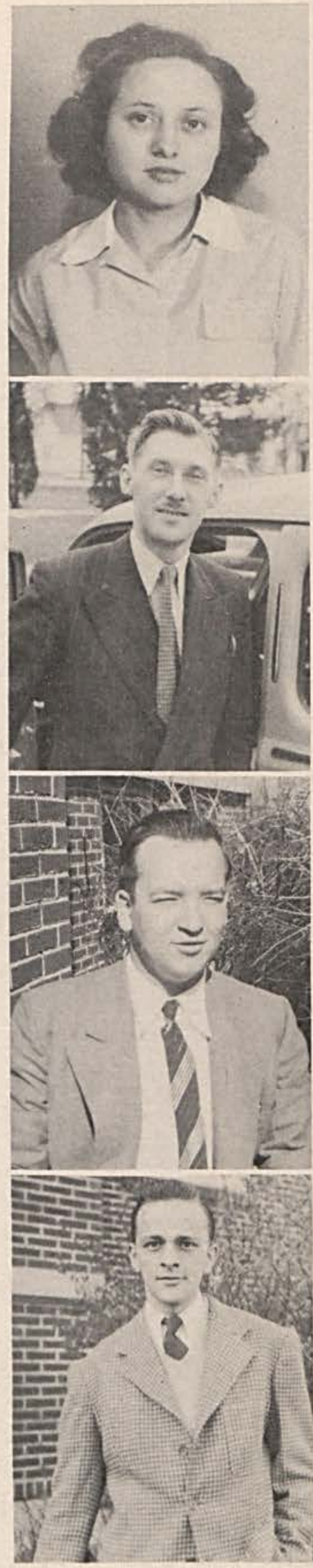



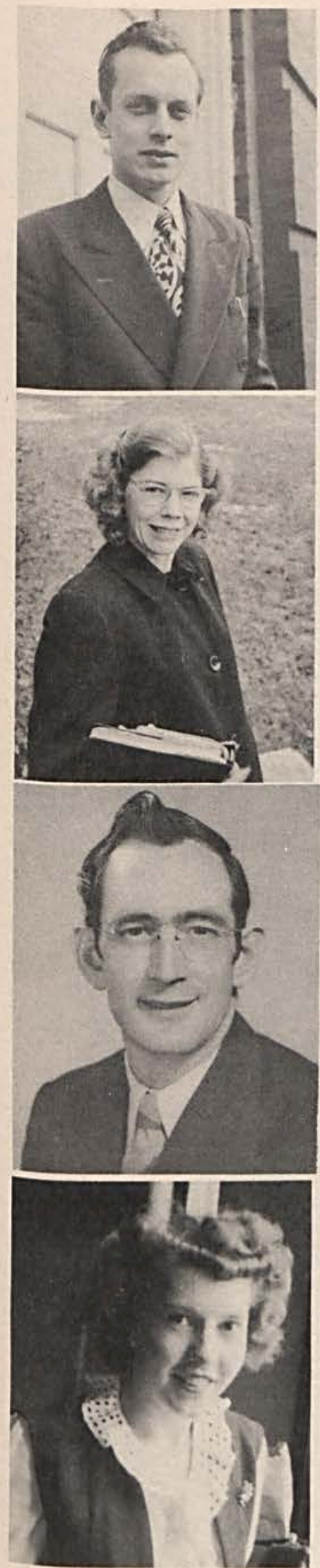

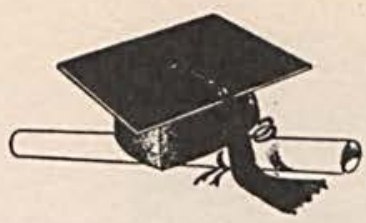

WILLIAM TROUTE Xenia, Ohio

Basketbal1 1,4: Chi Mu Delta fraternity; Student Council 4.

CONNER MERRITT

Jamestown, Ohio

\section{RUTH REITER \\ Cedarville, Ohio}

EDWIN RYAN

Newark, Ohio

Rio Grande College 1,2 Deputation Team 1; C. C. A. 1,2: Alpha Tau Deita Fra: ternity 1 ;. R' As soci ation 2: Grandion Staf (Business Manager) 1: In(Business Manager) 1: Intramurals 1: Chorus 1;
Orchestra 1; Basketbal1 2; Orchestra 1; Basketball 2;
Dramatics club 2; Veterans Club (Vice-President) 2 .

Cedarville College 3,4 Football Manager 3: Bas ketball Manager 3: Base. ba11 Manager $3 ;$ Y.M.C. A. 3, 4; F.T.A. 4; Editor of Year Book 4. "CC" Club 4 ; Class Vice-President 4.

HELEN TANNEHILL Clifton, Ohio

Cedarvil1e 1,2,3,4; Class President 1: Class Presi dent 2: Class Treasurer 3 ; Student Council Secretary 3; Y. W. C. A. 1, $2,3,4$ Y.W.C.A. Vice-President 2 Y.W.C.A. President 3; Ch $\mathrm{Sigma} \mathrm{Phi} 2,3,4 ; \mathrm{Ch}$ Sigma Phi Vice-president 4.
CARL WATKINS Cedarville, Ohio

Basketbal1 1,4: Chi Mu De1ta fraternity; Student Council president 4.

DONNA WATKINS

\section{Cedarville, Ohio}

Chi sigmaphi, president 4.

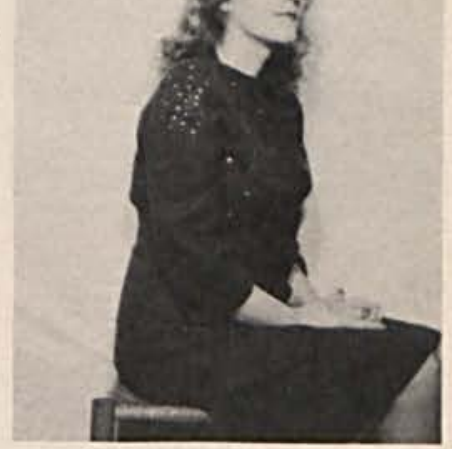

\section{SENIOR CLASS OFFICERS}

President . . . . Carl Watkins Vice-President . . . Edwin Ryan Secretary-Treasurer. Donna Watkins 


\section{CLASS OFFICERS}

President . . . . Willard Preston

Vice-President . . . Arthur Lewis Student Council

Representatives . . . Norman Potts Raymond Mullen

\section{Guniors}

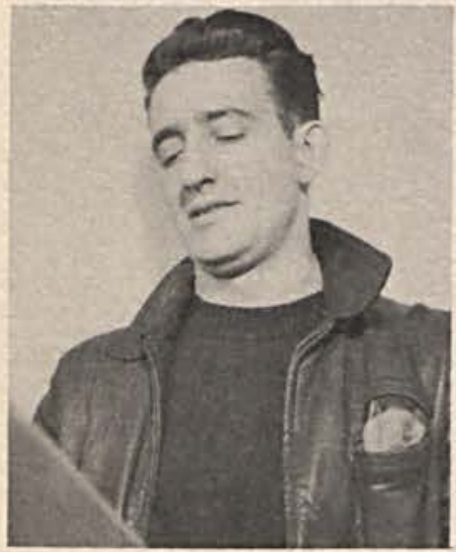

ROBERT FILER

Springfield, Ohio

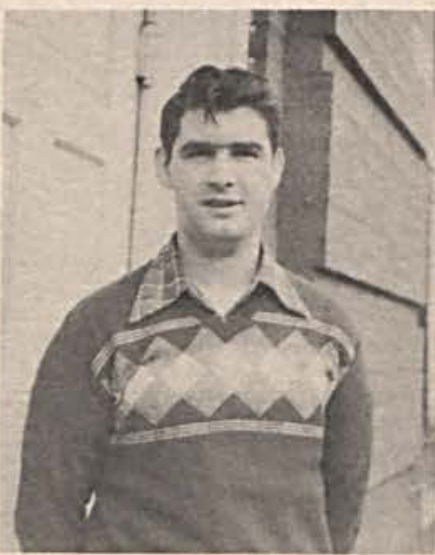

RAYMOND MULLEN

South Webster, Ohio

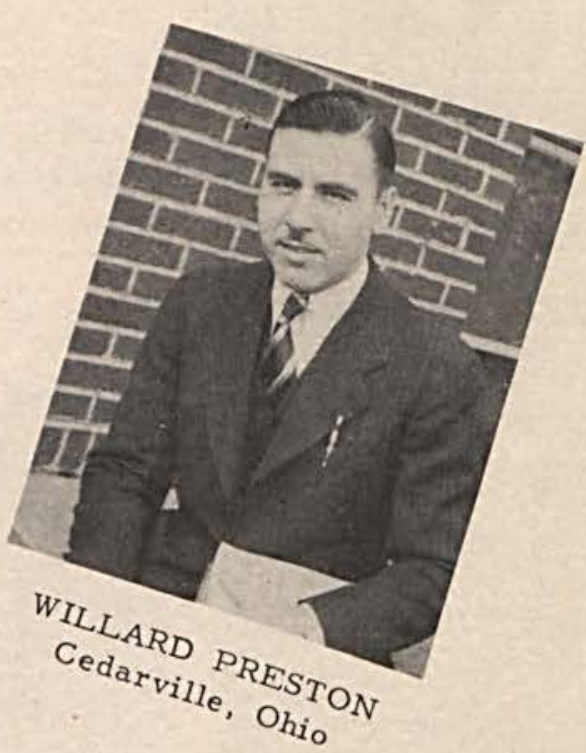

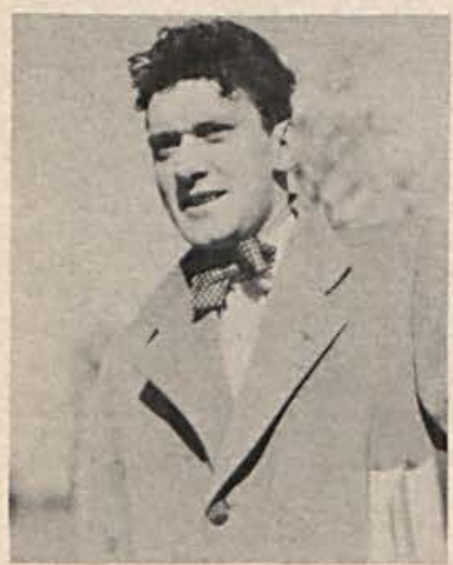

JOHN JAY CHECK

Lewistown, Pa.

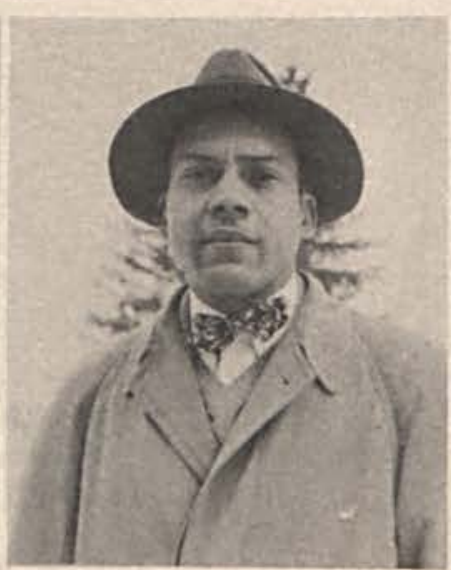

WILLIAM CLARK Lexington, Va.

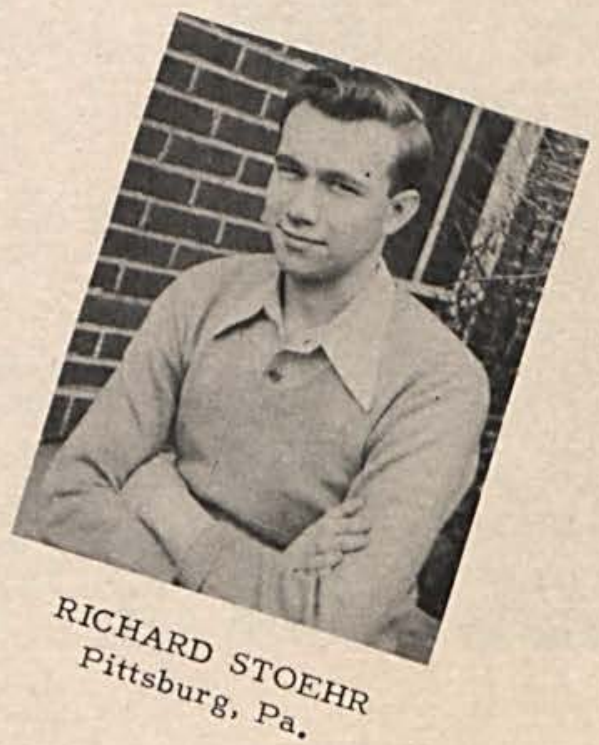




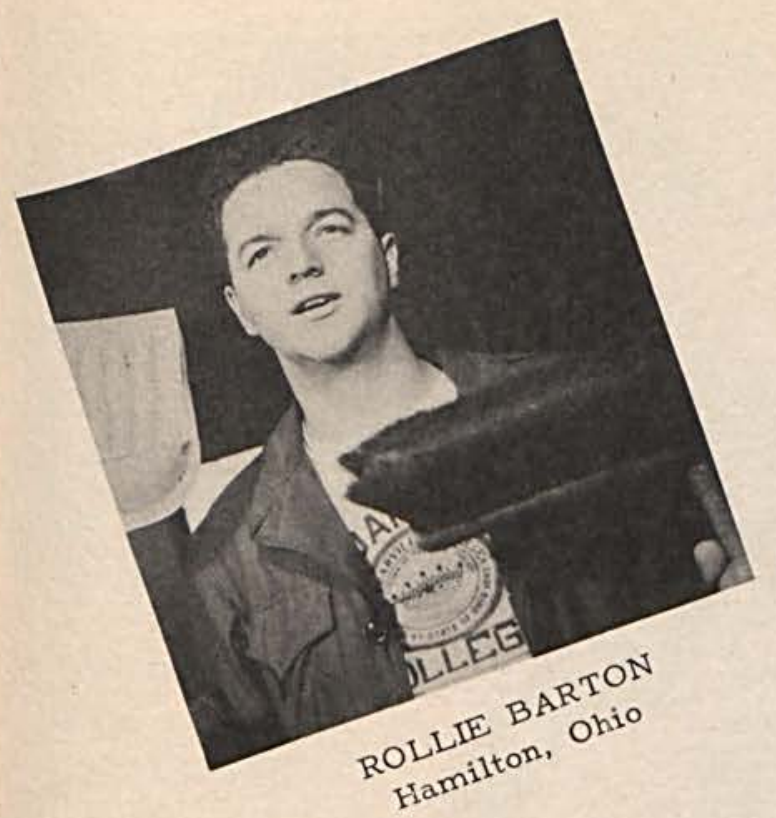

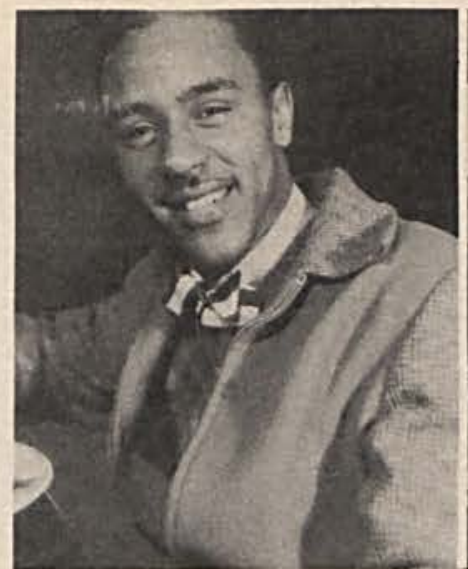

RICHARD BROWN

Harrisburg, Pennsylvania

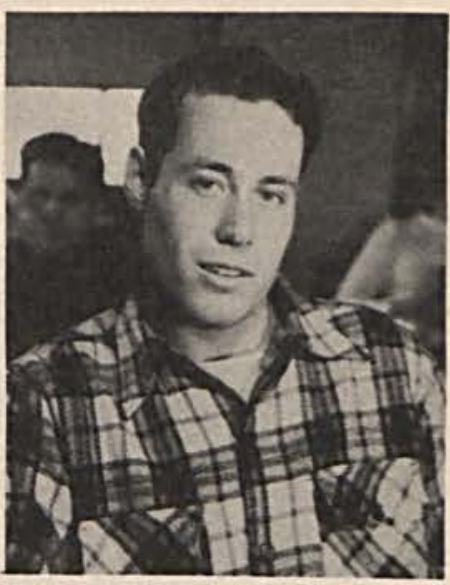

EUGENE SALLIE

New Burlington, Ohio

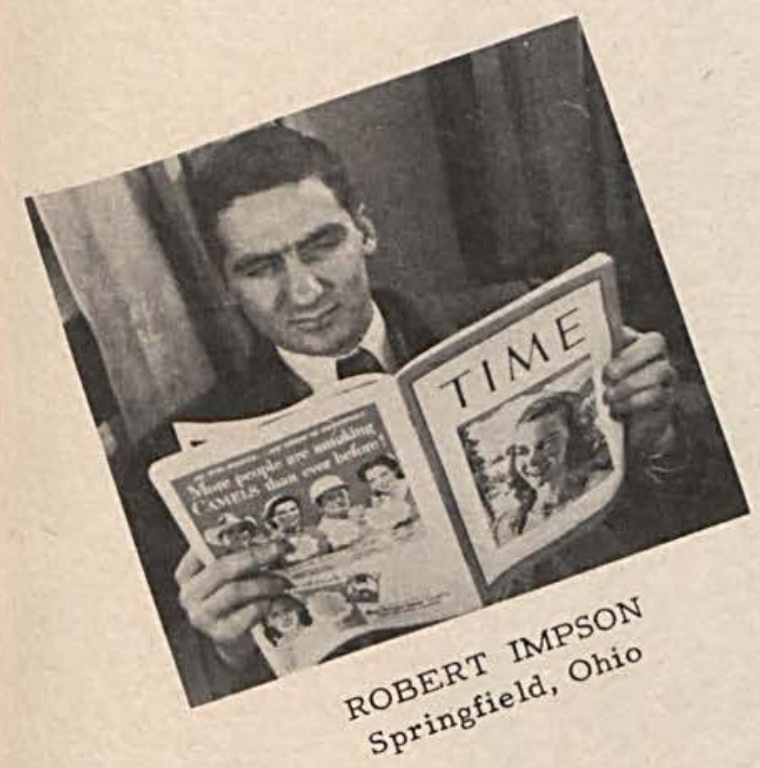

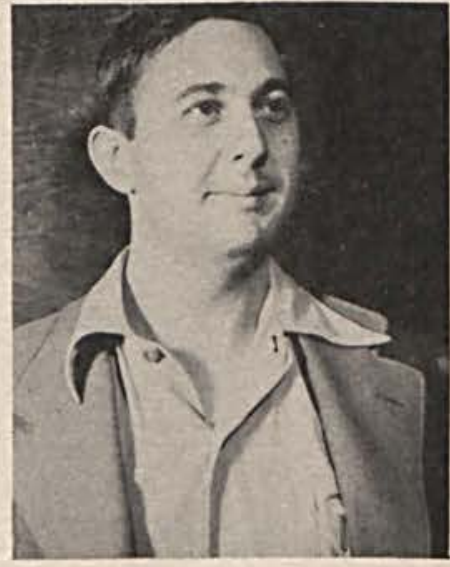

JOHN HAWKER

Dayton, Ohio

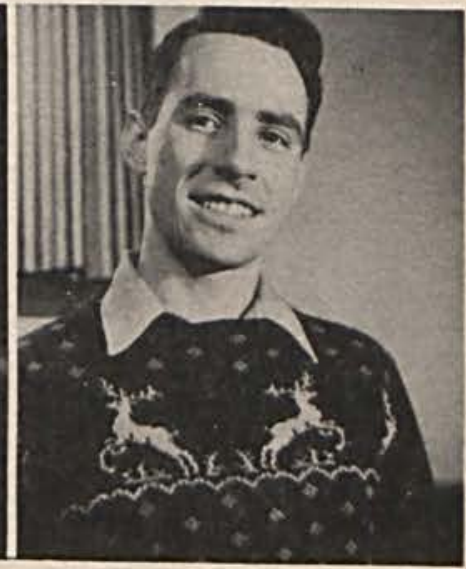

ARTHUR LEWIS

South Webster, Ohio

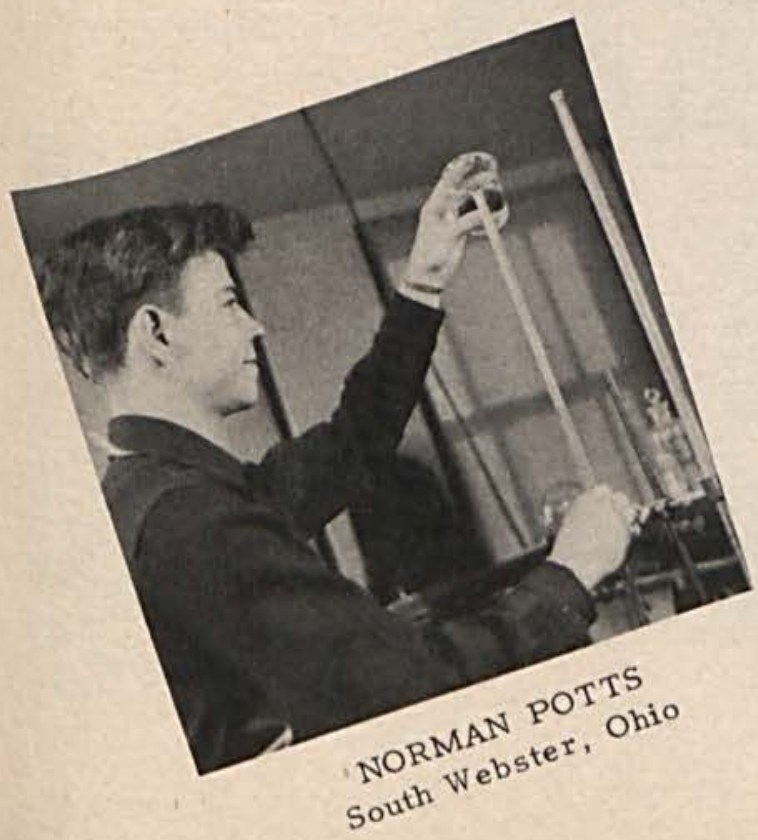

JAMES ROWE

London, Ohio

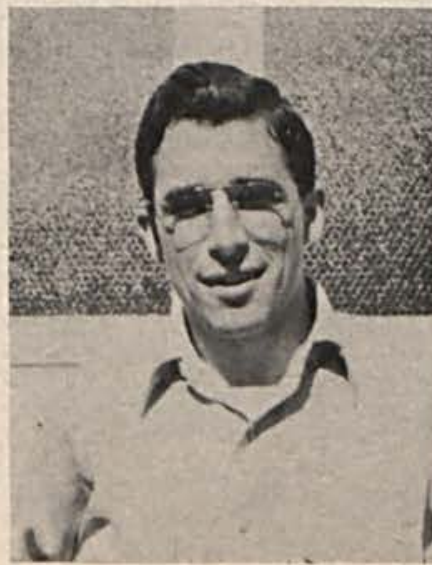

ARTHUR HARKINS

Springfield, Ohio

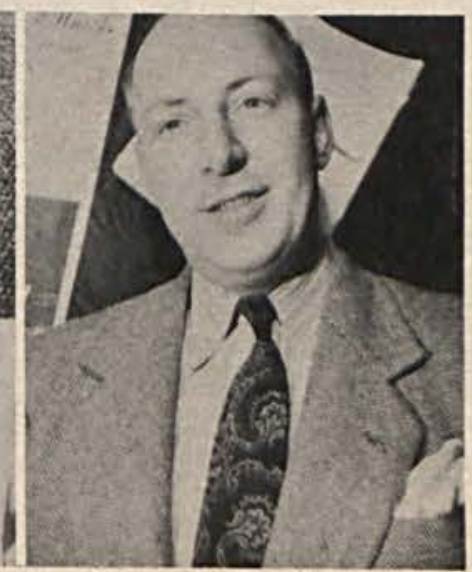




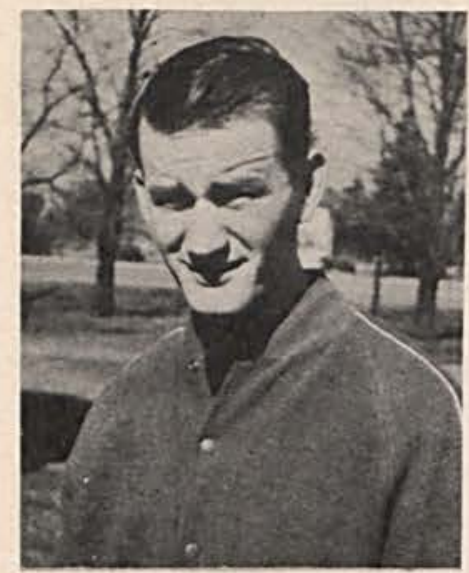

ROBERT RADER Manchester, Ohio

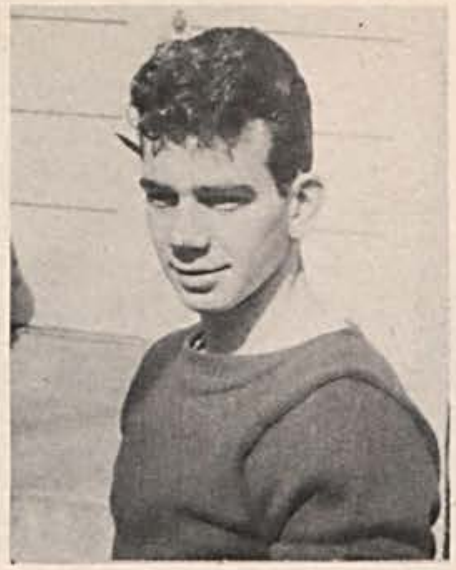

ALLEN LOOS

Hamilton, Ohio

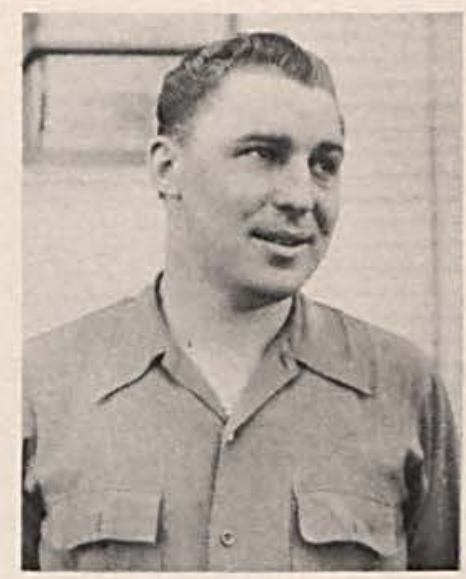

JOHN BLAZER

Cedarville, Ohio

\section{Sophomores}

ROGER ULSH

Springfield, Ohio

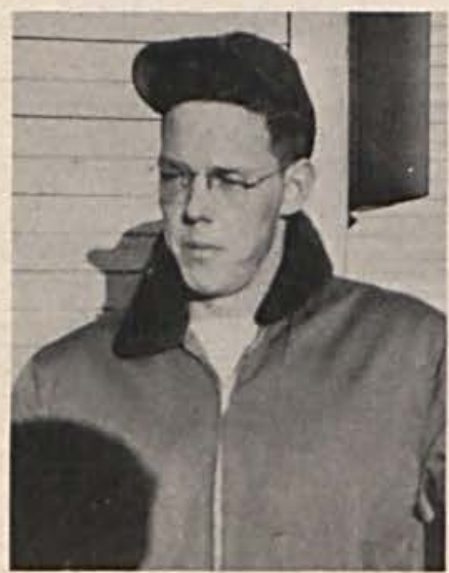

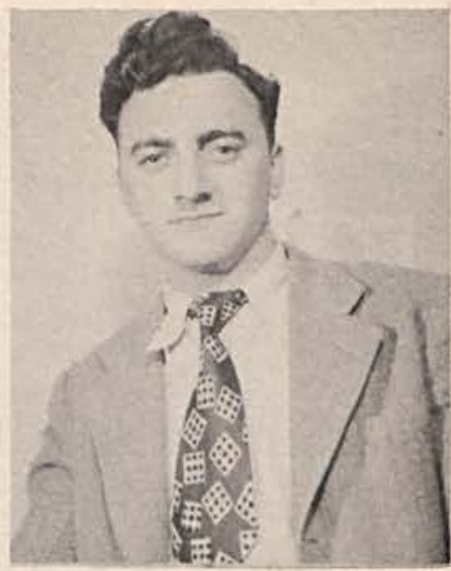

MILAN HAYDEN

Conemaugh, Pennsylvania

CF

$\mathrm{V}$

KENNETH WILBURN

Cedarville, Ohio

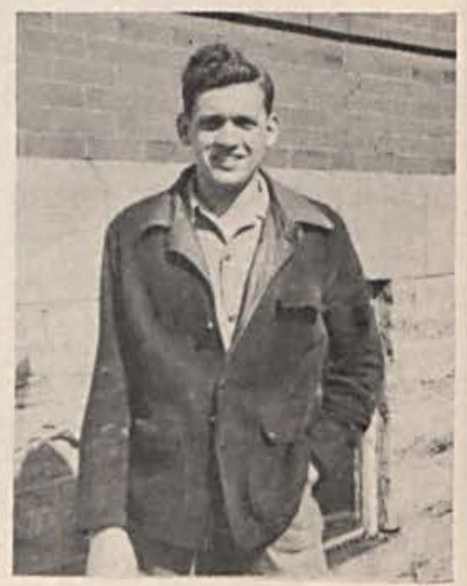




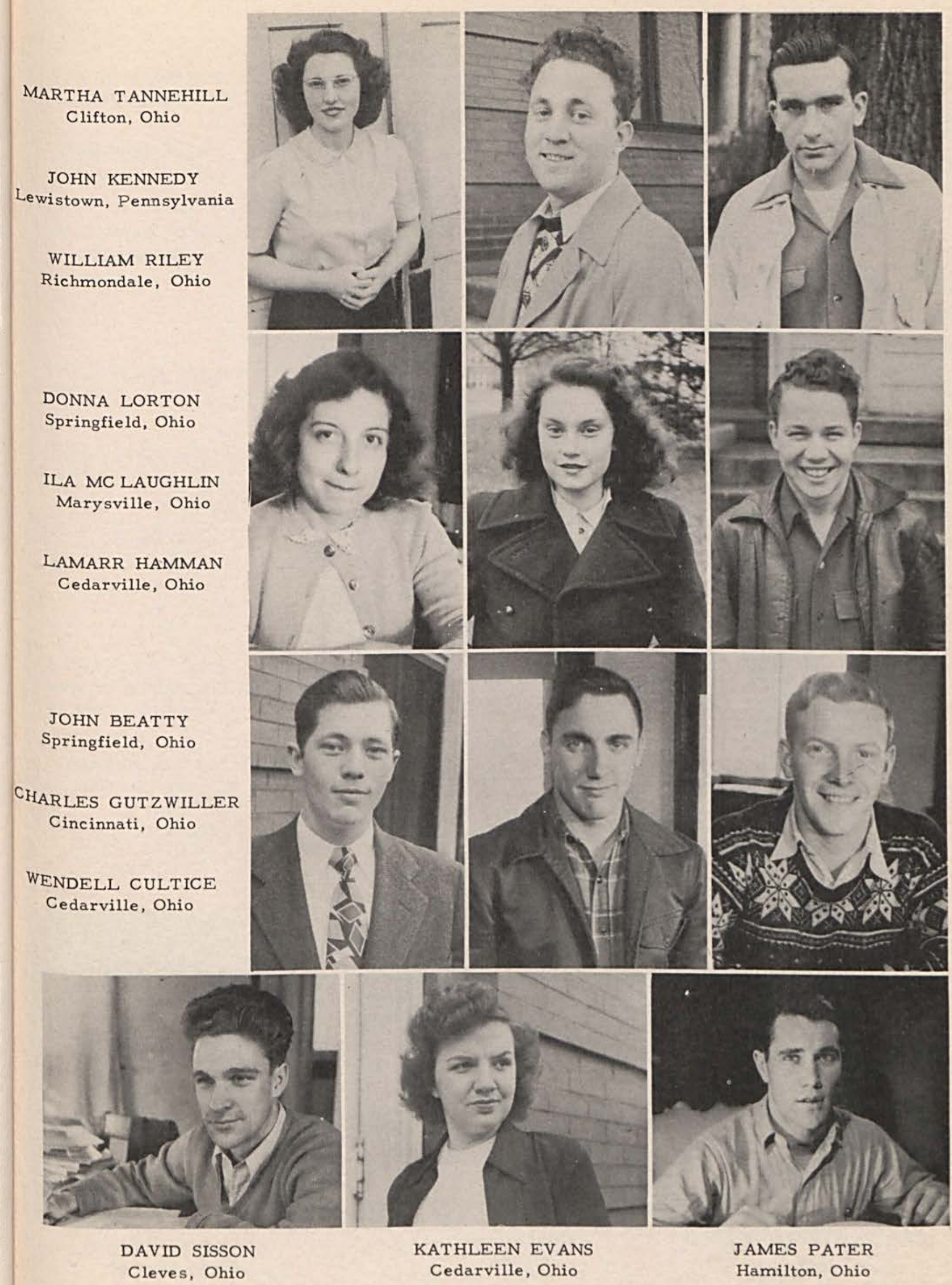



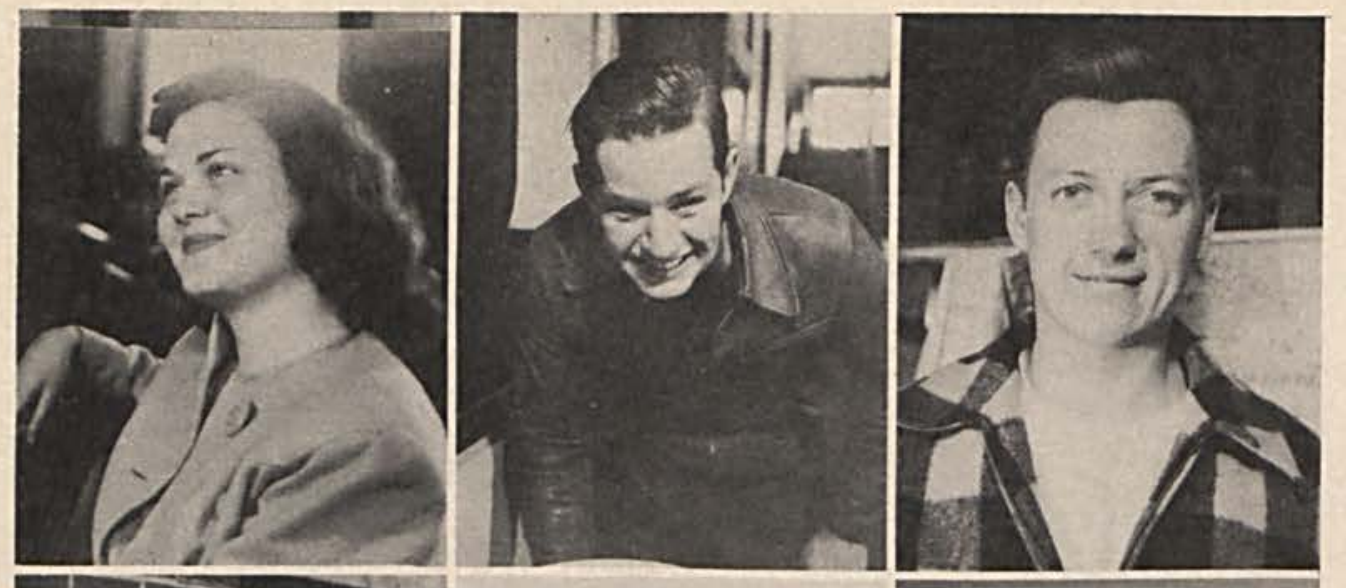
PATRICIA GRIEVE
Xenia, Ohio

ROSS JOHNSON

New Castle, Ind.

DON BARGER

Hamilton, Ohio
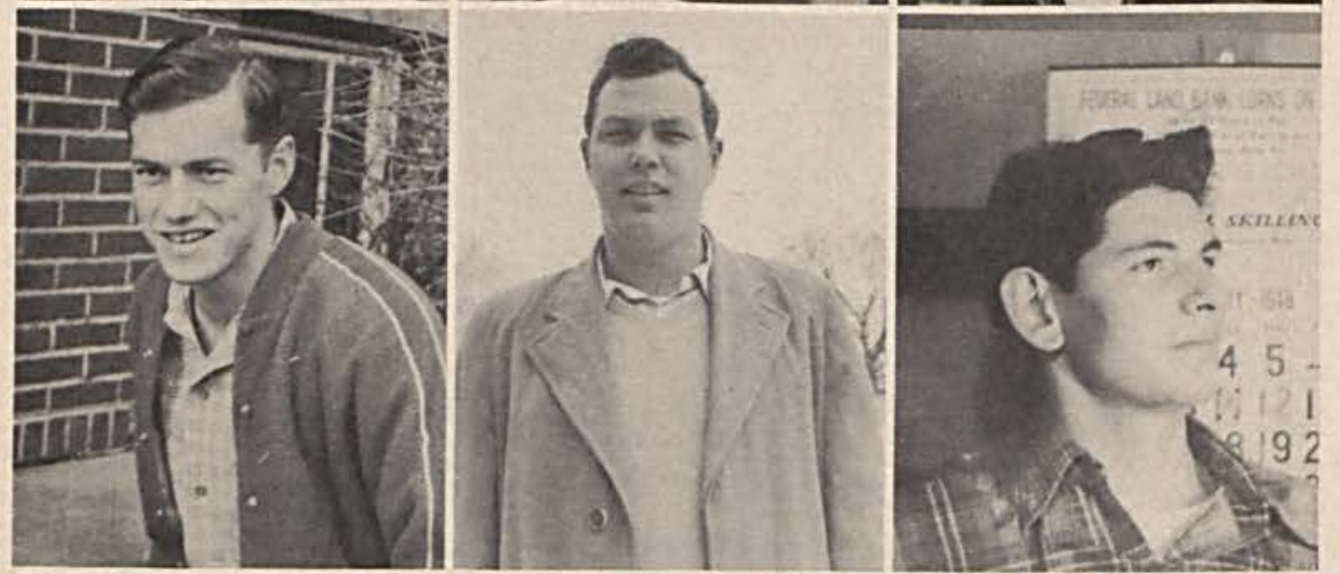

BEN MC NULTY

Manchester, Ohio

BION BRADBURY

Mercerville, Ohio

JOHN SKILLINGS

Clifton, Ohio
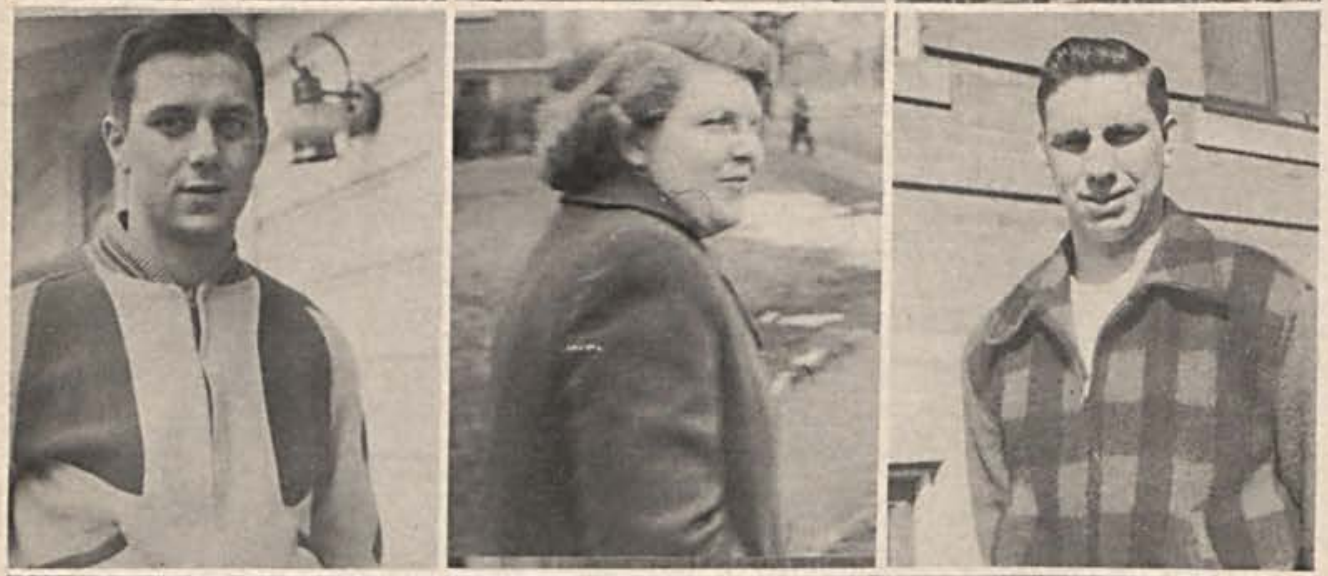

WILLIAM DUNLAP

Hamilton, Ohio

JOANNA BRYANT

Cedarville, Ohio

WILBUR MAUK

Sciotoville, Ohio

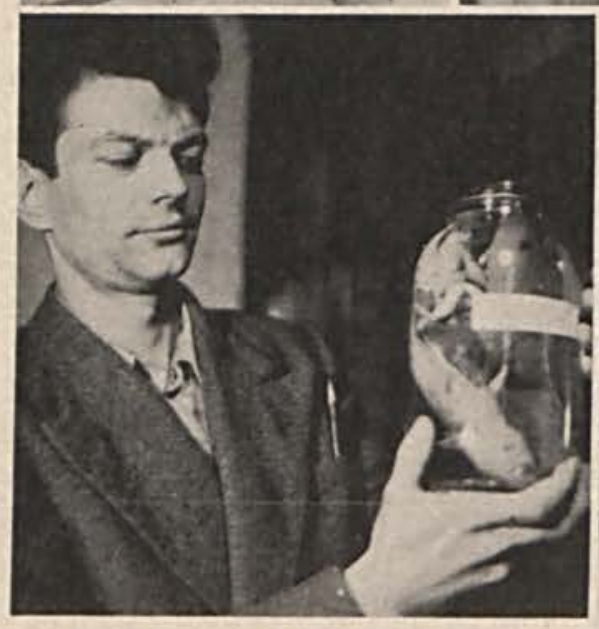

EMORY BEIREIS

Cedarville, Ohio

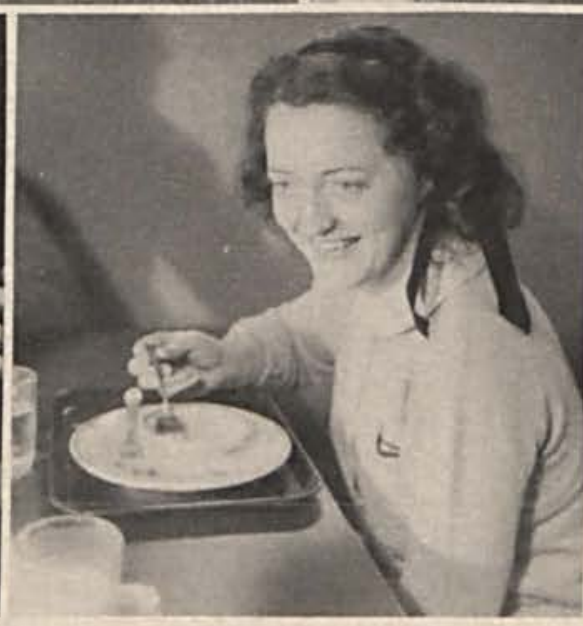

CHARLOTTE COLLINS

Xenia, Ohio

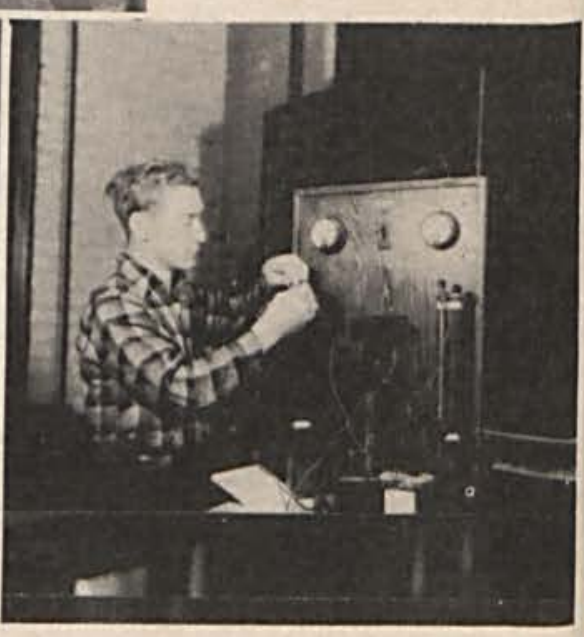

EARNEST FOSTER Dunbar, Ohio 
MAX BITLER

Lancaster, Ohio

CLIFFORD BREWER Cedarville, Ohio

KENNETH HUFFMAN Cedarville, Ohio

HAROLD MACHAMER Lewistown, Pennsylvania

CHARLES MC GUFFIN Manchester, Ohio

MARIE FISHER Clayton, Ohio

FRANKLIN RUDY

Lewistown, Pennsylvania

JOHN TOWNSLEY

Cedarville, Ohio

BETTY RINEHART

Cedarville, Ohio
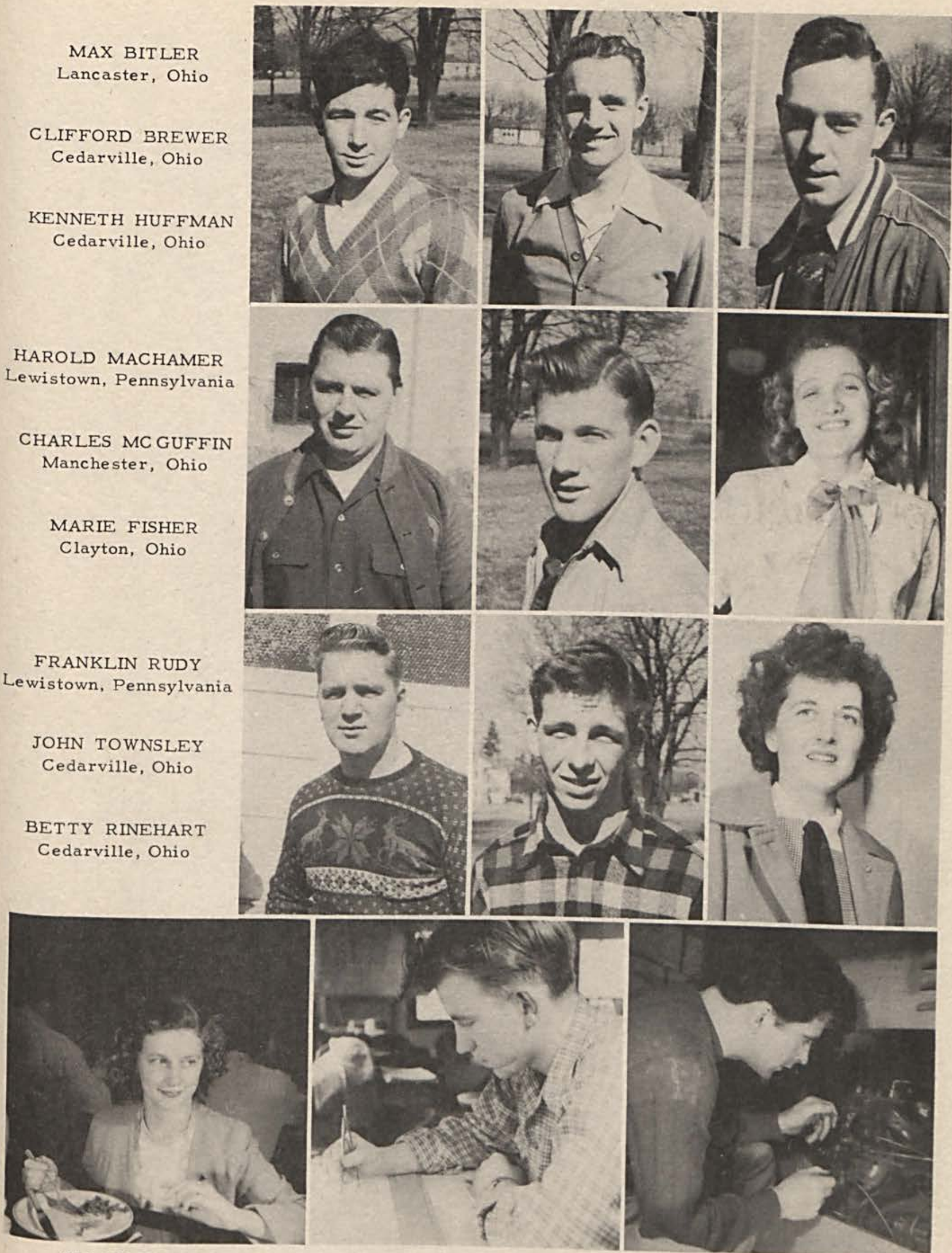

SALLY FLANNERY

Plattsburg, Ohio

MARTIN WEIMER

Cedarville, Ohio

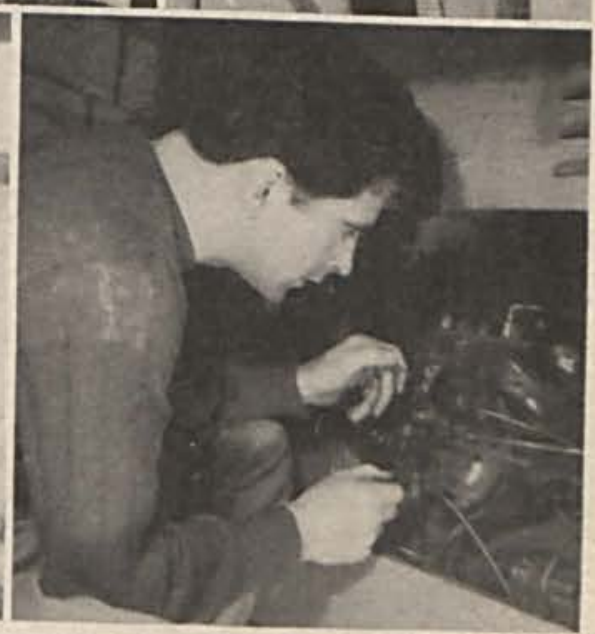

DONALD WHEATON

Akron, Ohio 


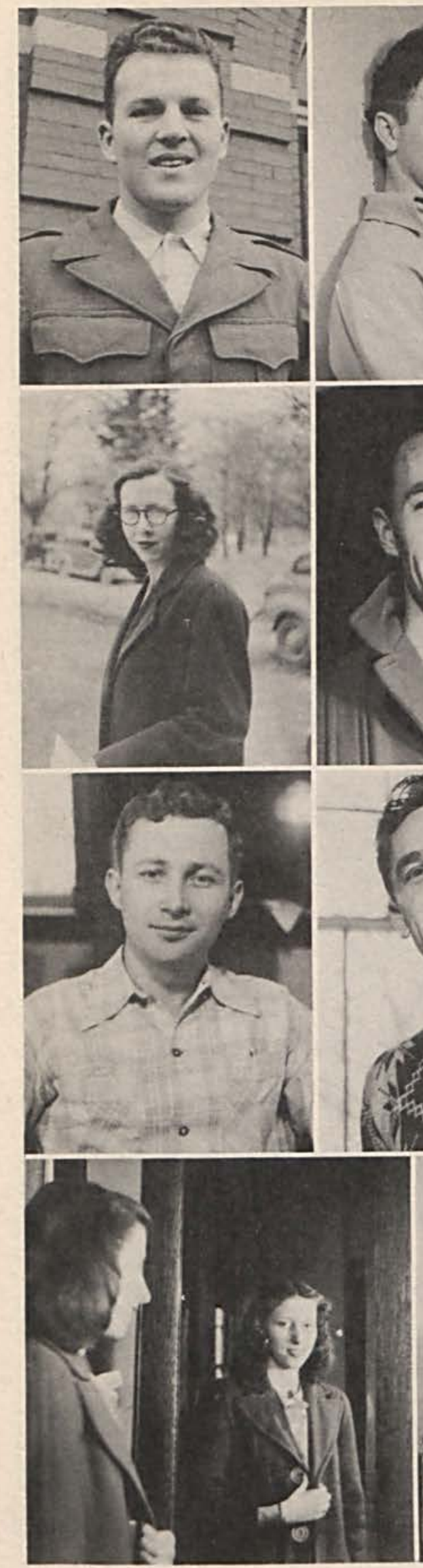

MARTHA WEISMILLER Selma, Ohio
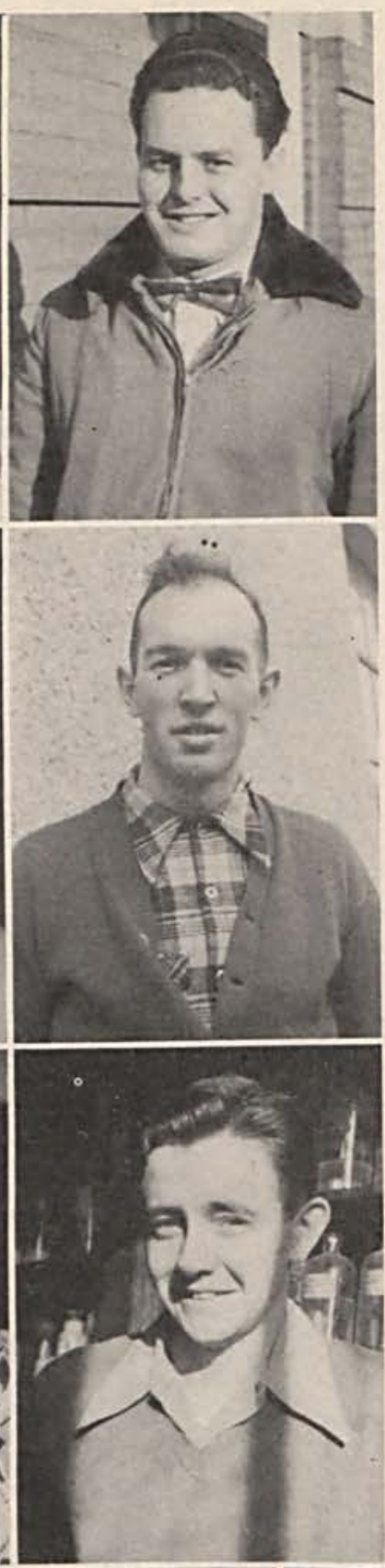

CHARLES W. DAVIS

Bainbridge, Ohio

JAMES LEWIS

Oak Hill, Ohio

JOHN HOLDERBY

Springfield, Ohio

MARTHA MC GUINN

Cedarville, Ohio

WILLIAM MC GUINN

Cedarville, Ohio

KENNETH JUDY

Cedarville, Ohio

WILLIAM METTERHOUSE

Somerville, New Jersey

ADOLPH MASLAR

Raritan, New Jersey

KEITH ROGERS

Jamestown, Ohio

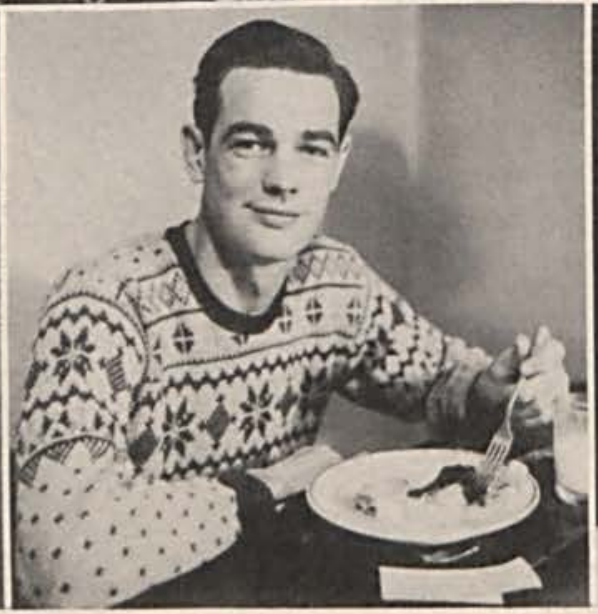

CHARLES W. RADER Manchester, Ohio

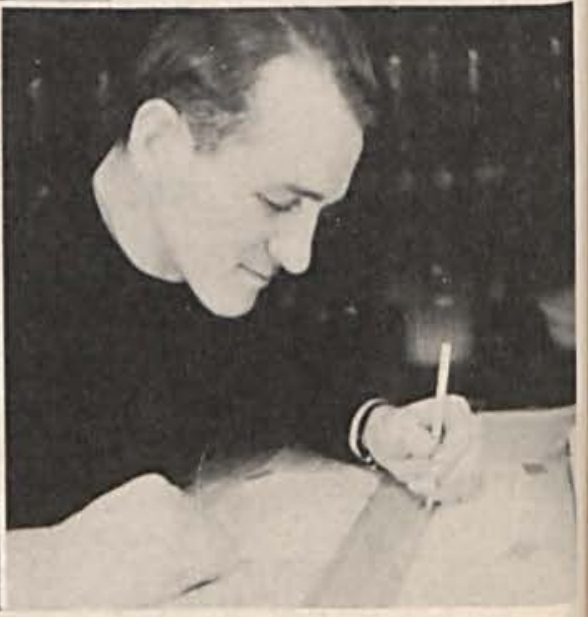

PARK KING

Cedarville, Ohio 


\section{Freshmen}

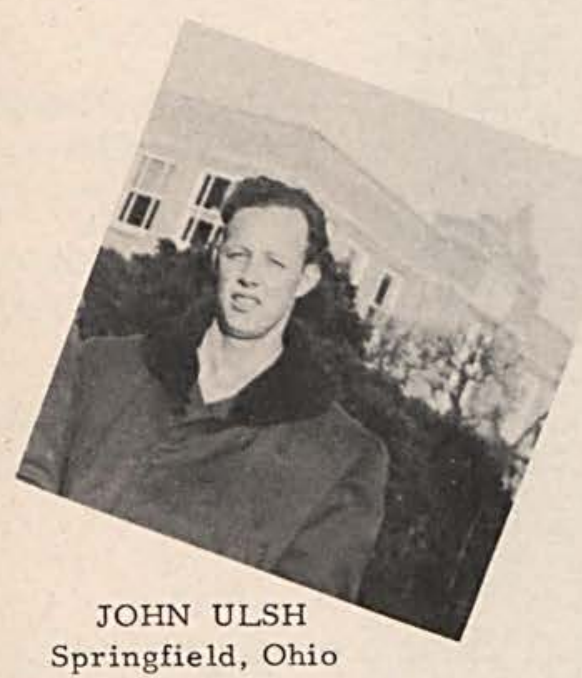

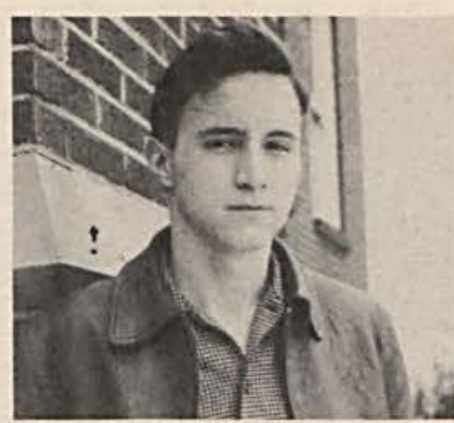

GEORGE IRVING

Cedarville, Ohio

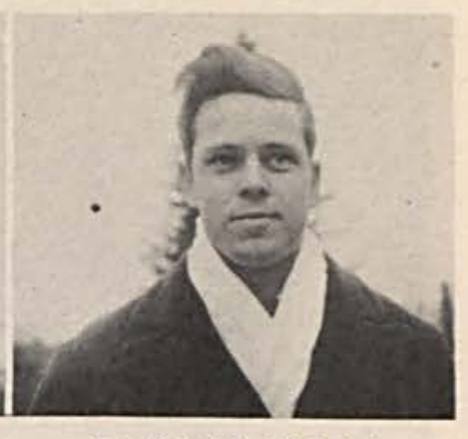

GEORGE WATT

Dayton, Ohio

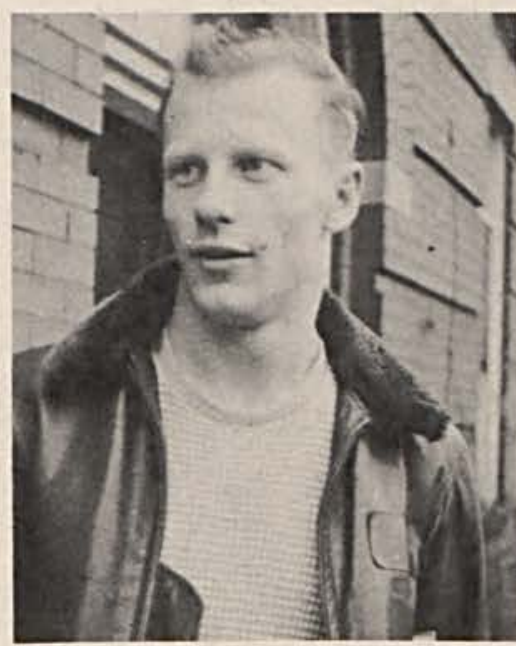

RICHARD FREE Springfield, Ohio

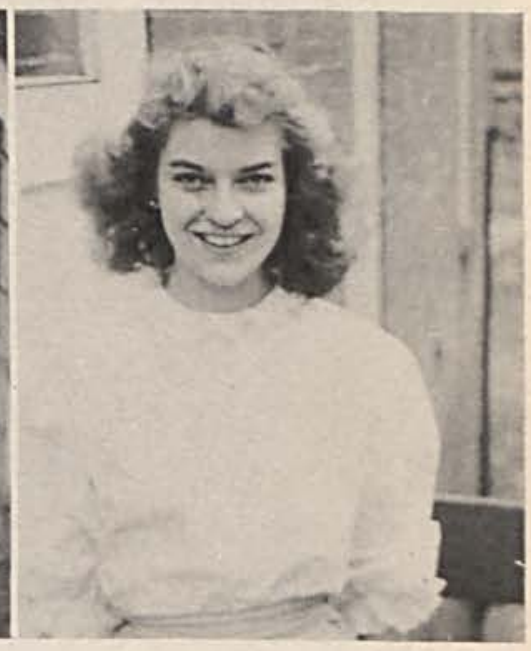

RONOLDA RILEY

Chillicothe, Ohio

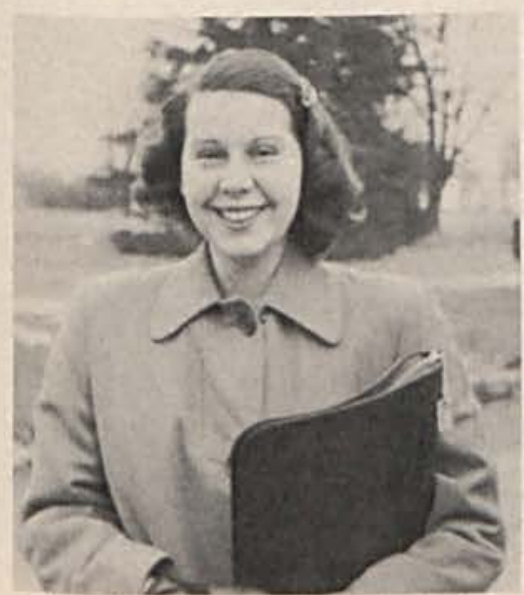

MARGARET SHELEY Hamilton, Ohio

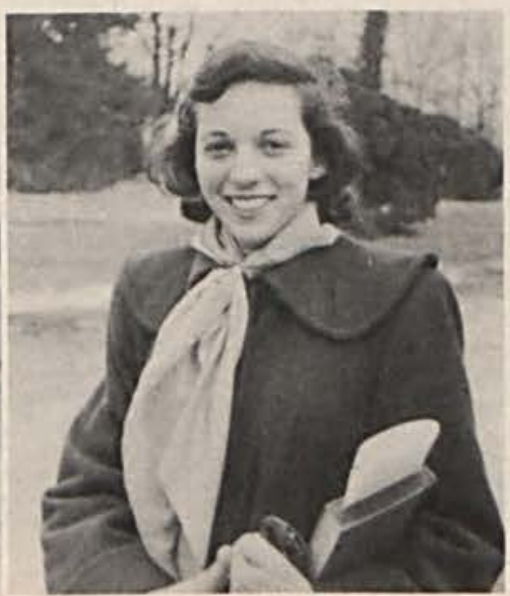

MARY FELLOWS

Chillicothe, Ohio

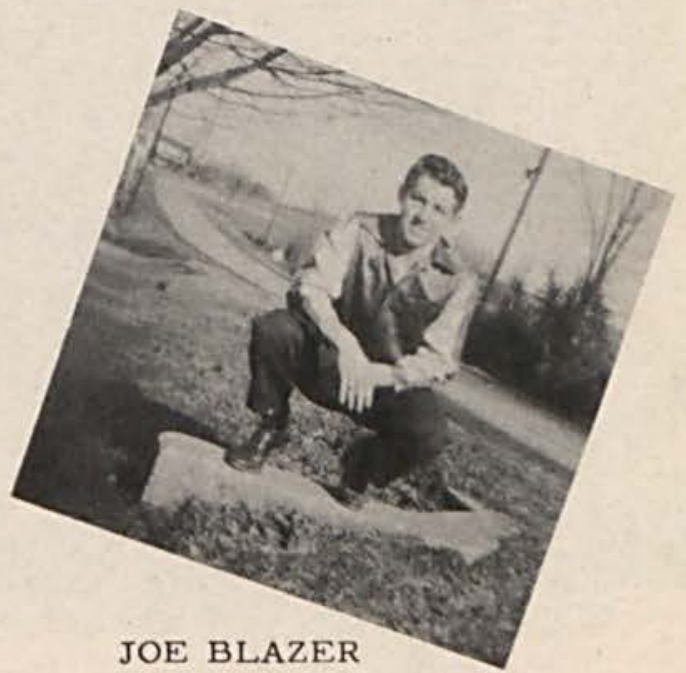

Rio Grande, Ohio 


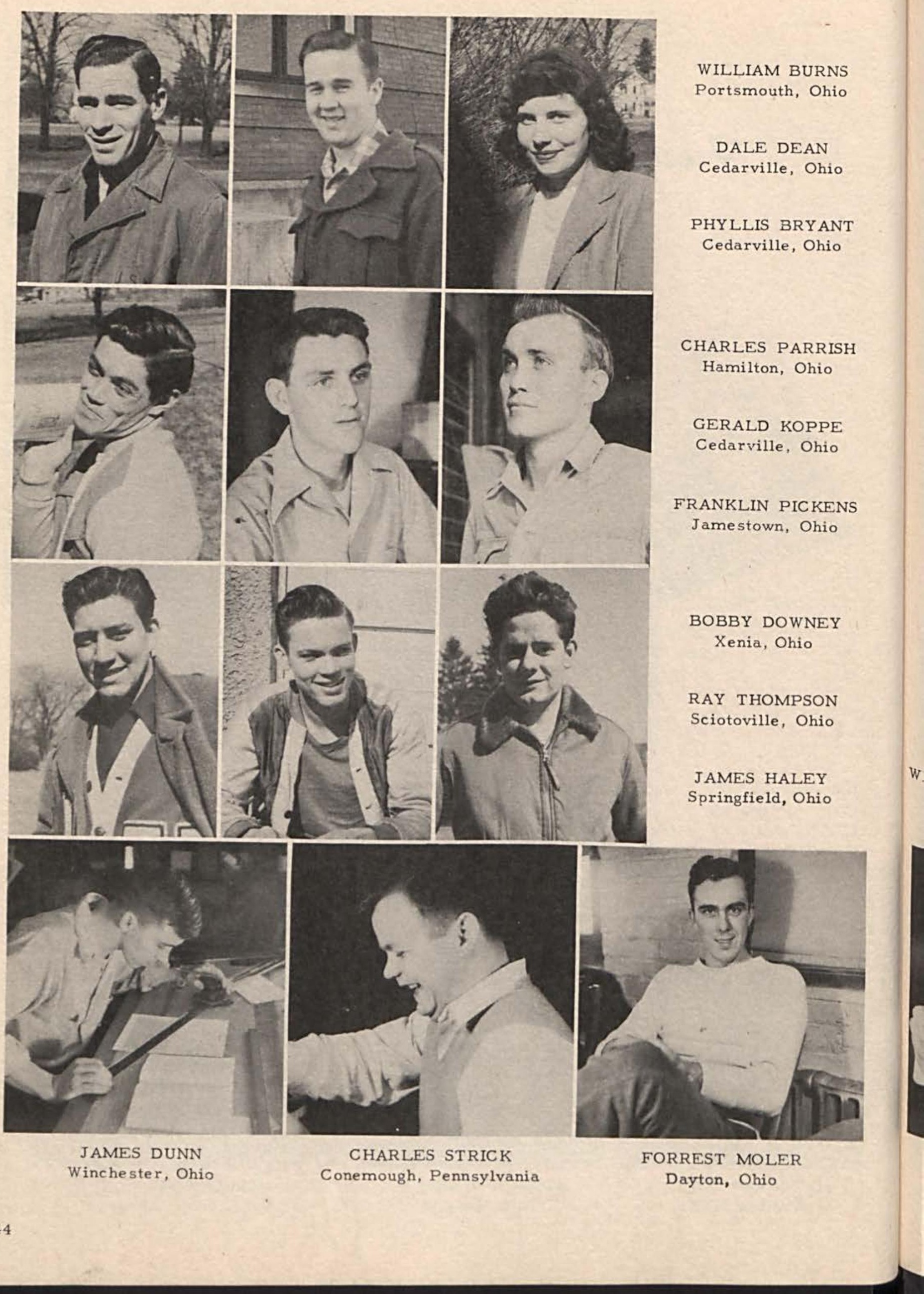


EARNEST STANLEY

Portsmouth, Ohio

NORMAN CHARLES

Cedarville, Ohio

GLENN SHUMATE

South Webster, Ohio

JOHN STEWART

Cedarville, Ohio

CLAY COTTLE

Sciotoville, Ohio

JAMES WISECUP

Cedarville, Ohio

CARL WISEMAN

Cedarville, Ohio

ROBERT WARNER

Xenia, Ohio

WILLIS HIGGINBOTHAM

Springfield, Ohio

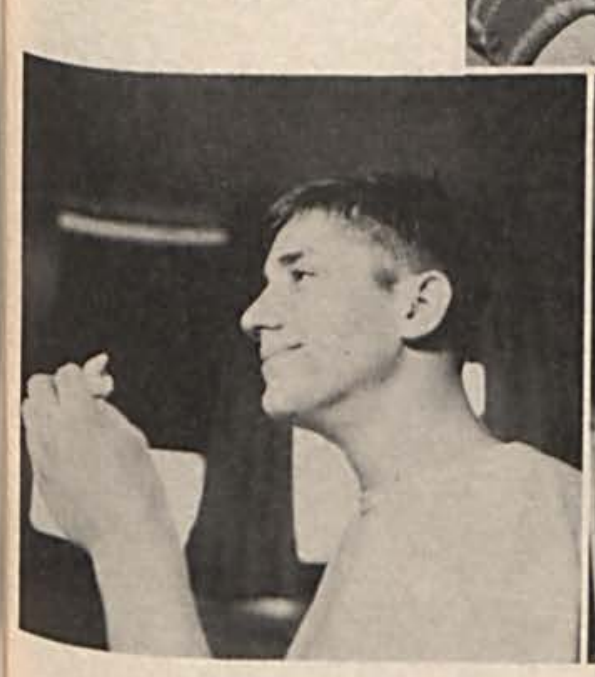

JAY FRY

Hamilton, Ohio
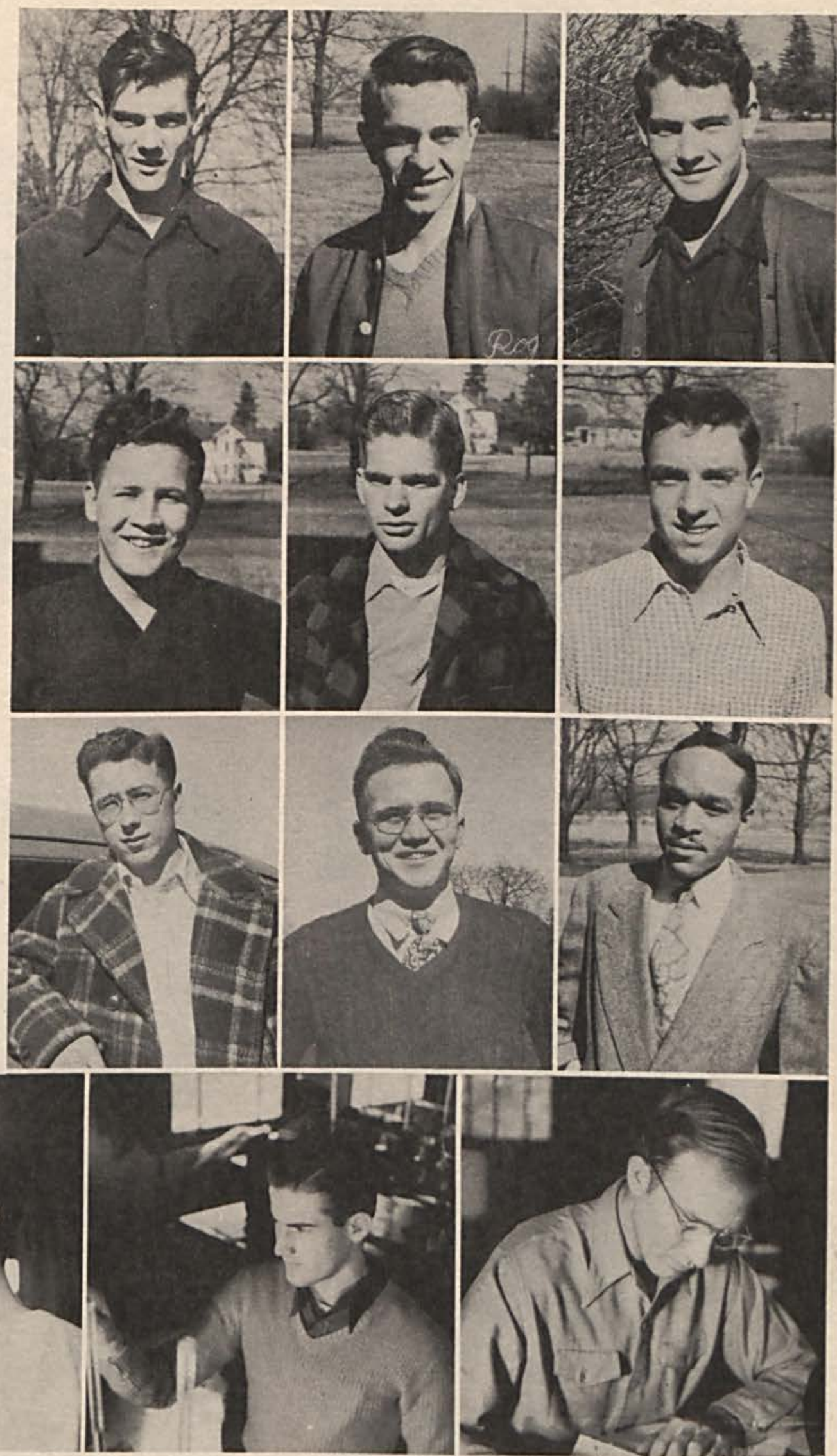

WILLIAM SCHLECHTY

London, Ohio

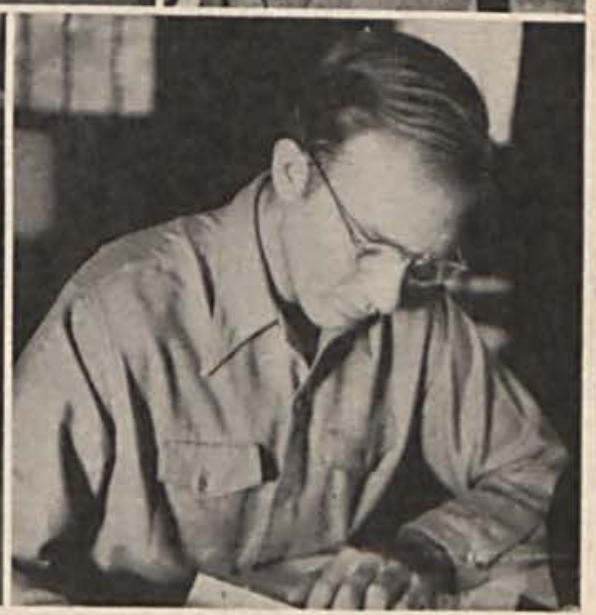

LAWRENCE MELVILLE Springfield, Ohio 


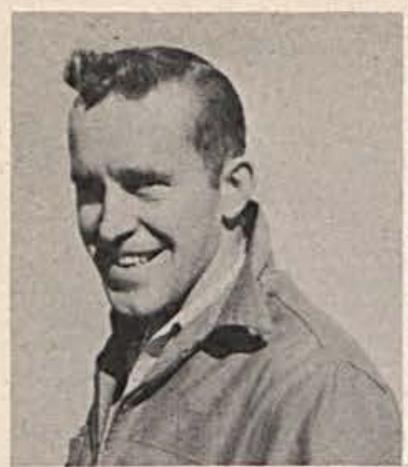

CLARION GROSS Lewistown, Pennsylvania

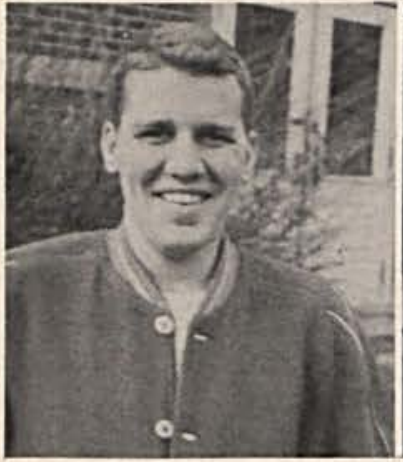

ROBERT HILDRETH Dayton, Ohio
WILLIAM PURDOM

Cedarville, Ohio
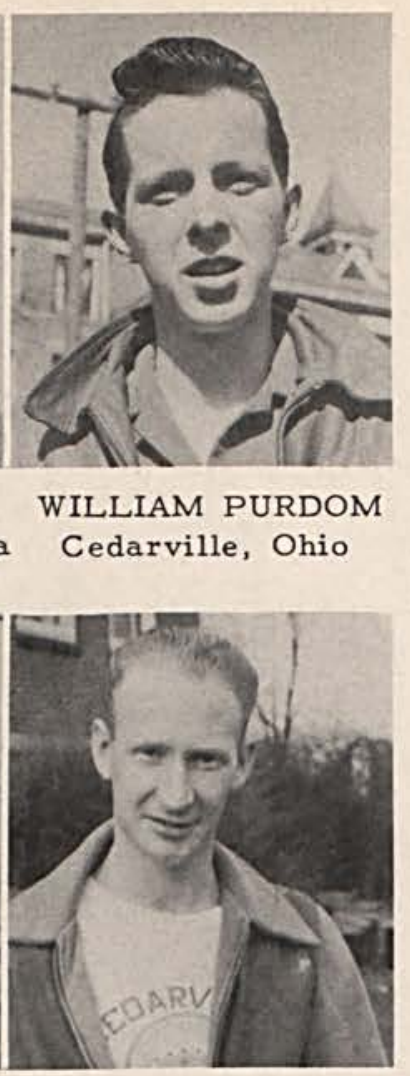

ELBERT BROOKS Cedarville, Ohio

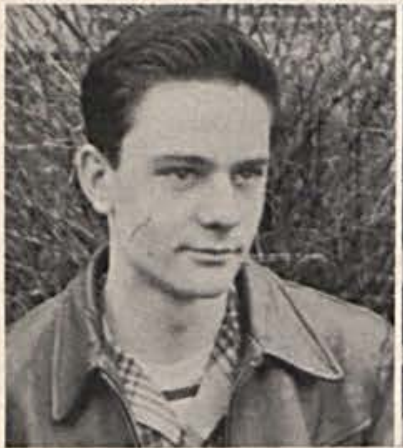

EDWIN BOYER

Cedarville, Ohio

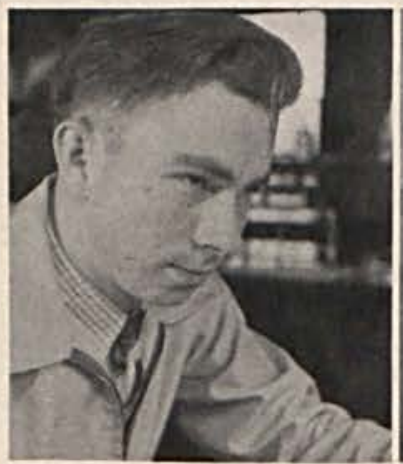

CHARLES BOASE

Cedarville, Ohio

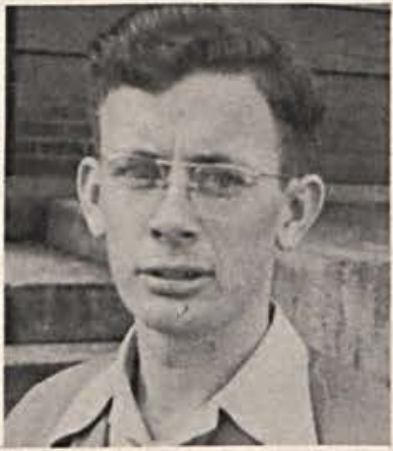

WILLIAM OSMAN Manchester, Ohio

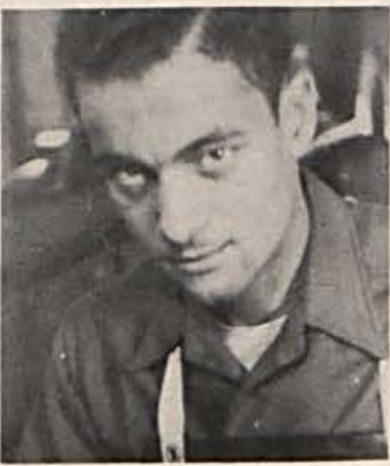

CARL JONES

Cedarville, Ohio
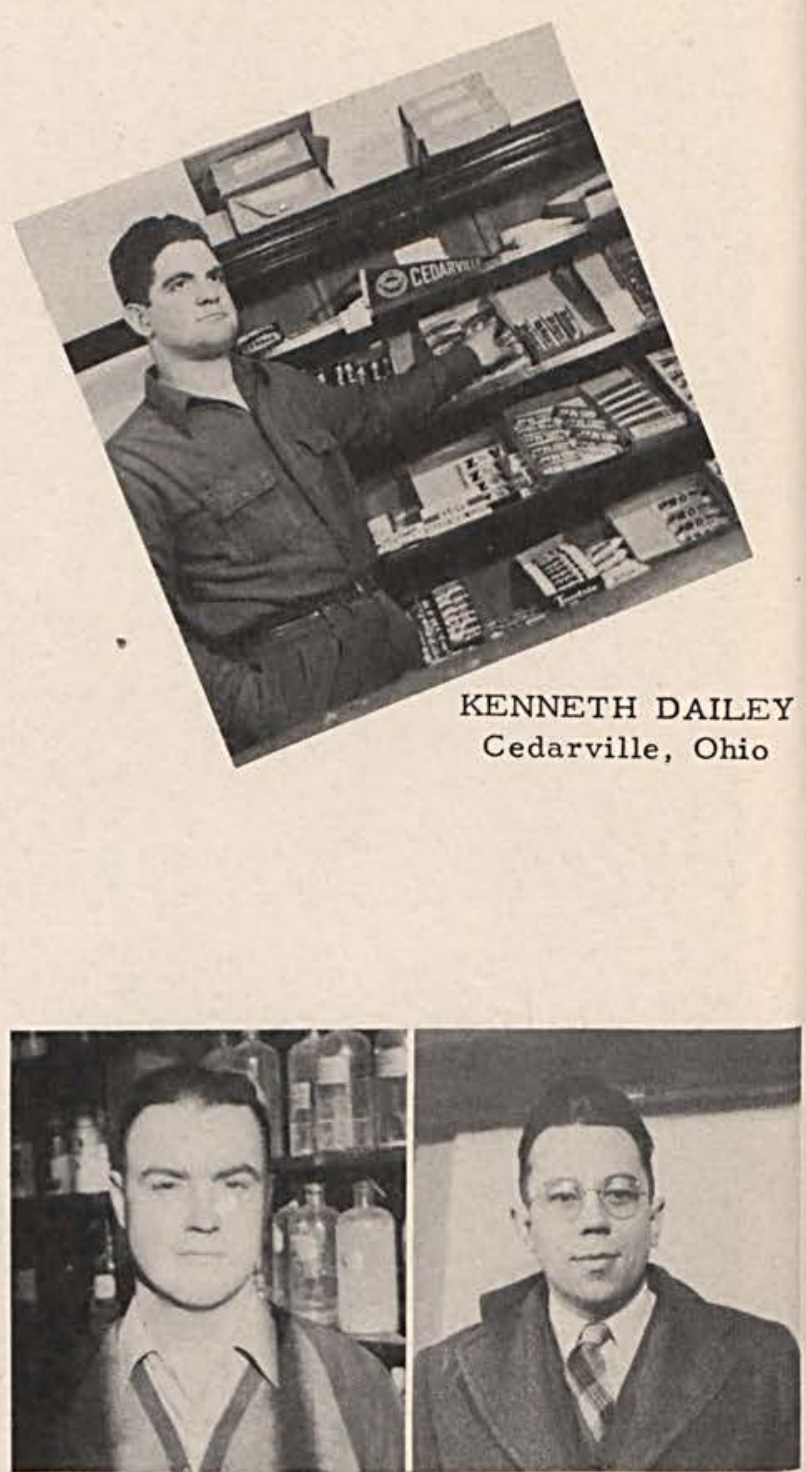

RALPH SCHAFER Jamestown, Ohio

JOSEPH PRICE

Christiansburg, Ohio

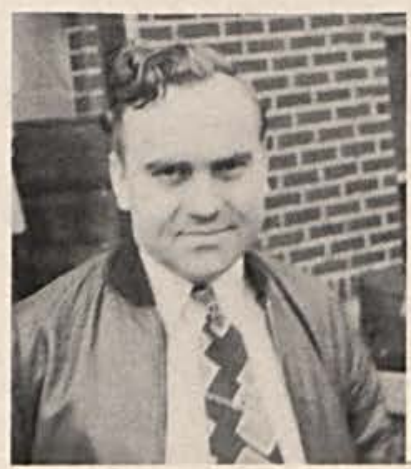

PAUL PRICE

Urbana, Ohio

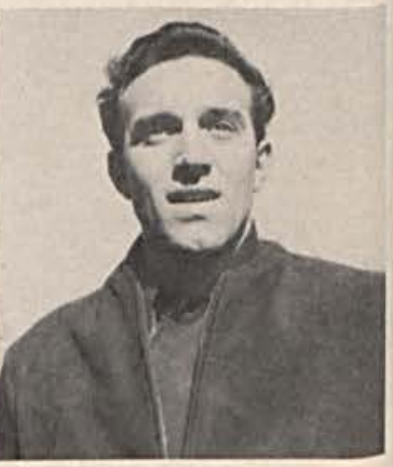

GENE CULTICE Troy, Ohio 


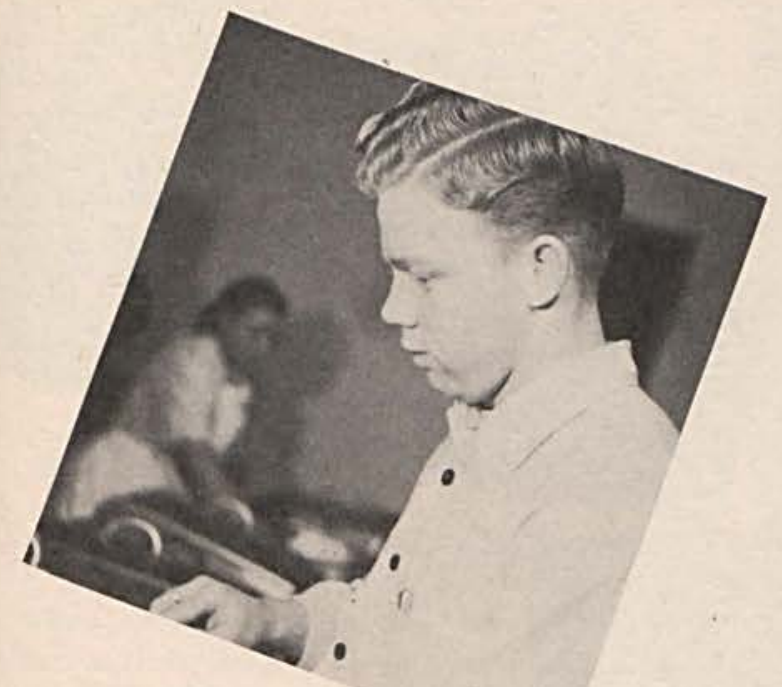

DONALD NOCK

Dayton, Ohio

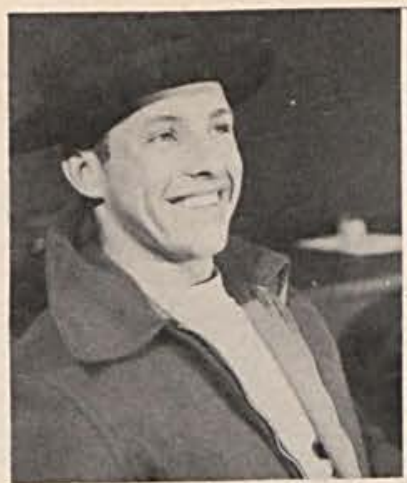

DILLARD MARCUM Hamilton, Ohio

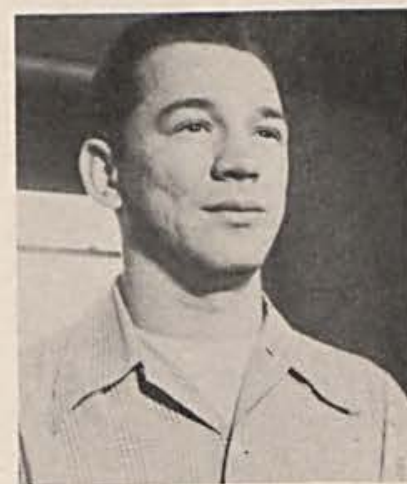

WALTER SEWAK

Johnstown, Pennsylvania

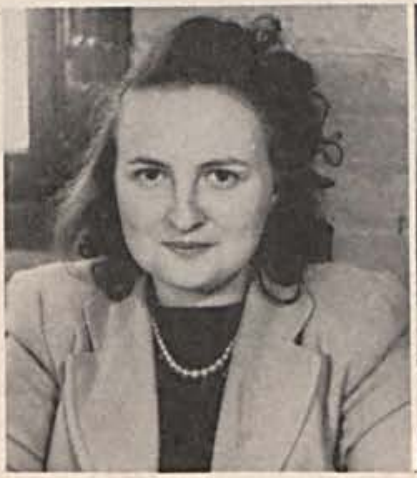

RUTH IRVINE

Cedarville, Ohio

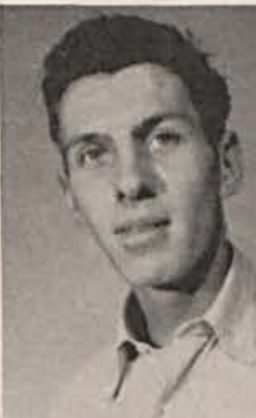

EMERSON ACKISON Xenia, Ohio

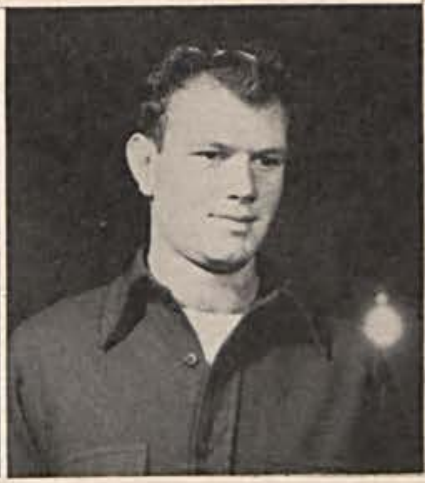

WILLIAM HAMMOND

Sciotoville, Ohio

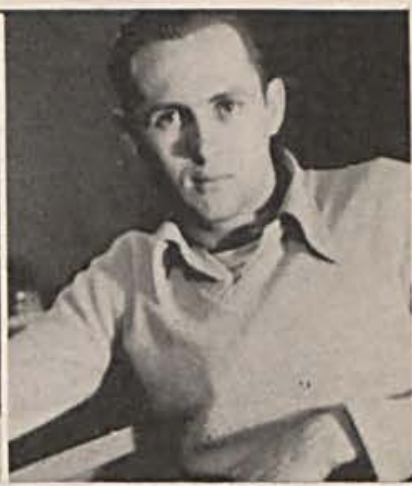

JAMES ROSS

South Webster, Ohio

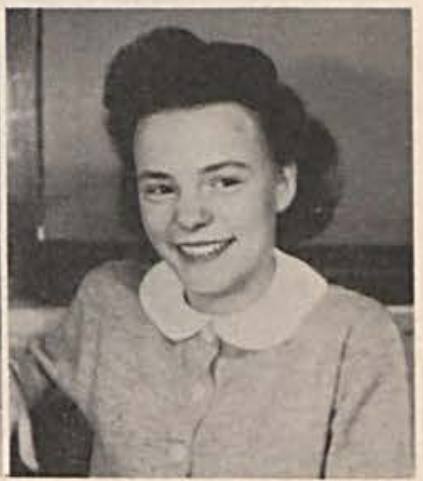

NAOMI CONNER

Cedarville, Ohio

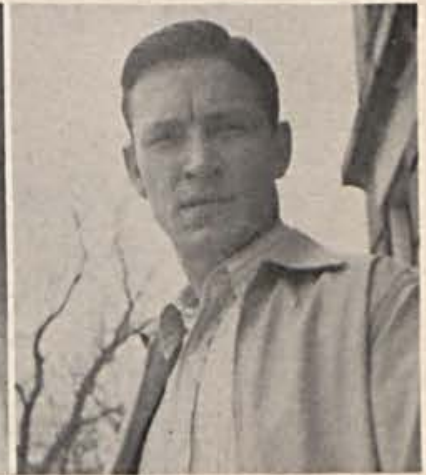

BILL CUNNINGHAM Portsmouth, Ohio 


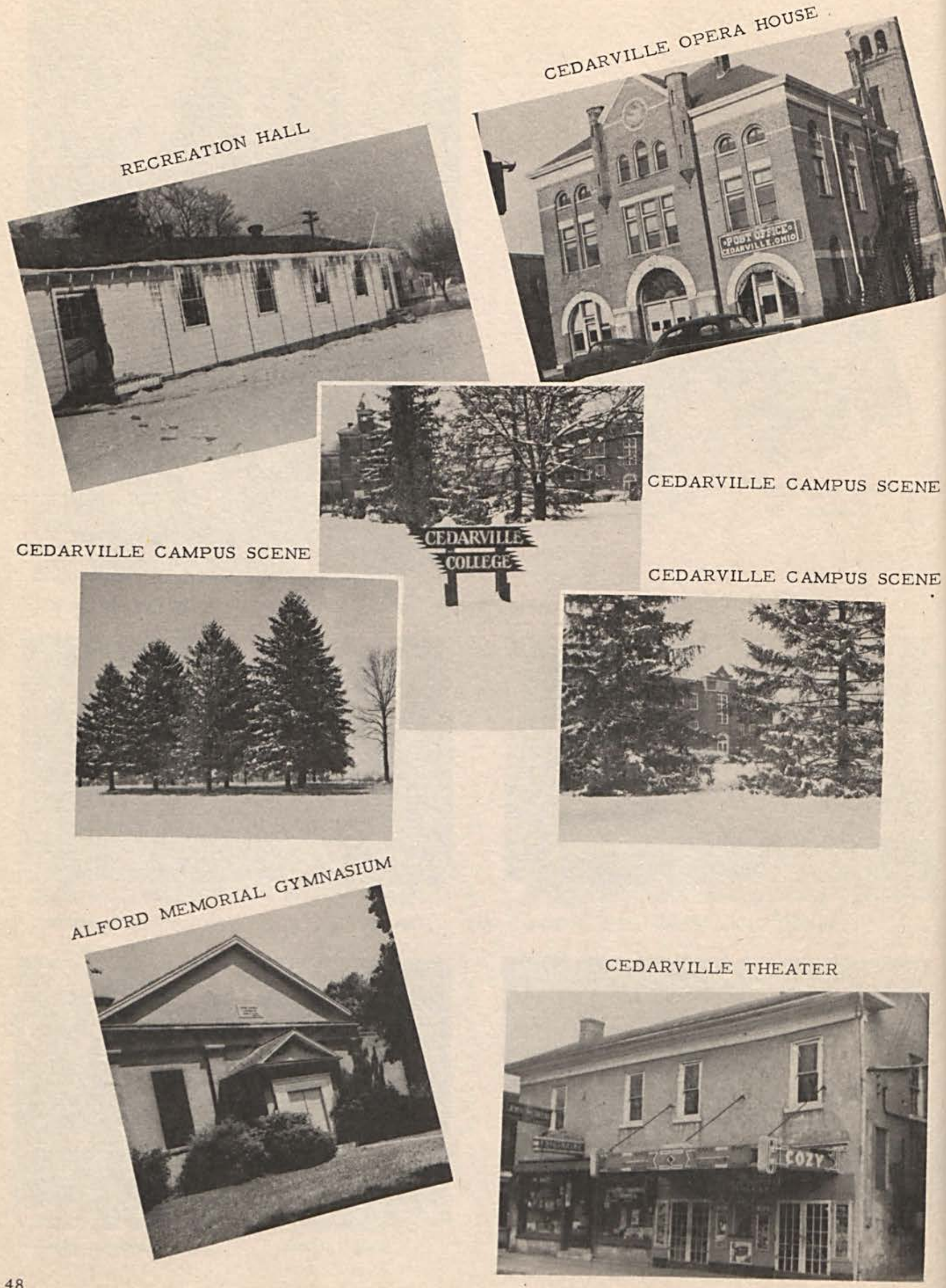




\section{Fomecoming}

One of the most colorful events of the school year at Cedarville is Homecoming Day, observed in 1947 on October 4. Pleasant weather, a beautiful queen, and a football victory combined to make the day a success.

A parade from the college to Cox Field began the program. During halftime of the homecoming game the queen, Mrs. J ay Check, and her attendants, Mrs. Carl Watkins and Miss Beatrice Knecht were introduced to the alumni. An alumni banquet was held in Alford Memorial Gymnasium in the evening and the annual homecoming dance ended the day's festivities.

The queen and attendants wereelected by student votes. Mrs. Check is a freshman in the education department and Cedarville's only woman veteran. Mrs. Watkins is a senior, Miss Knecht a sophomore.
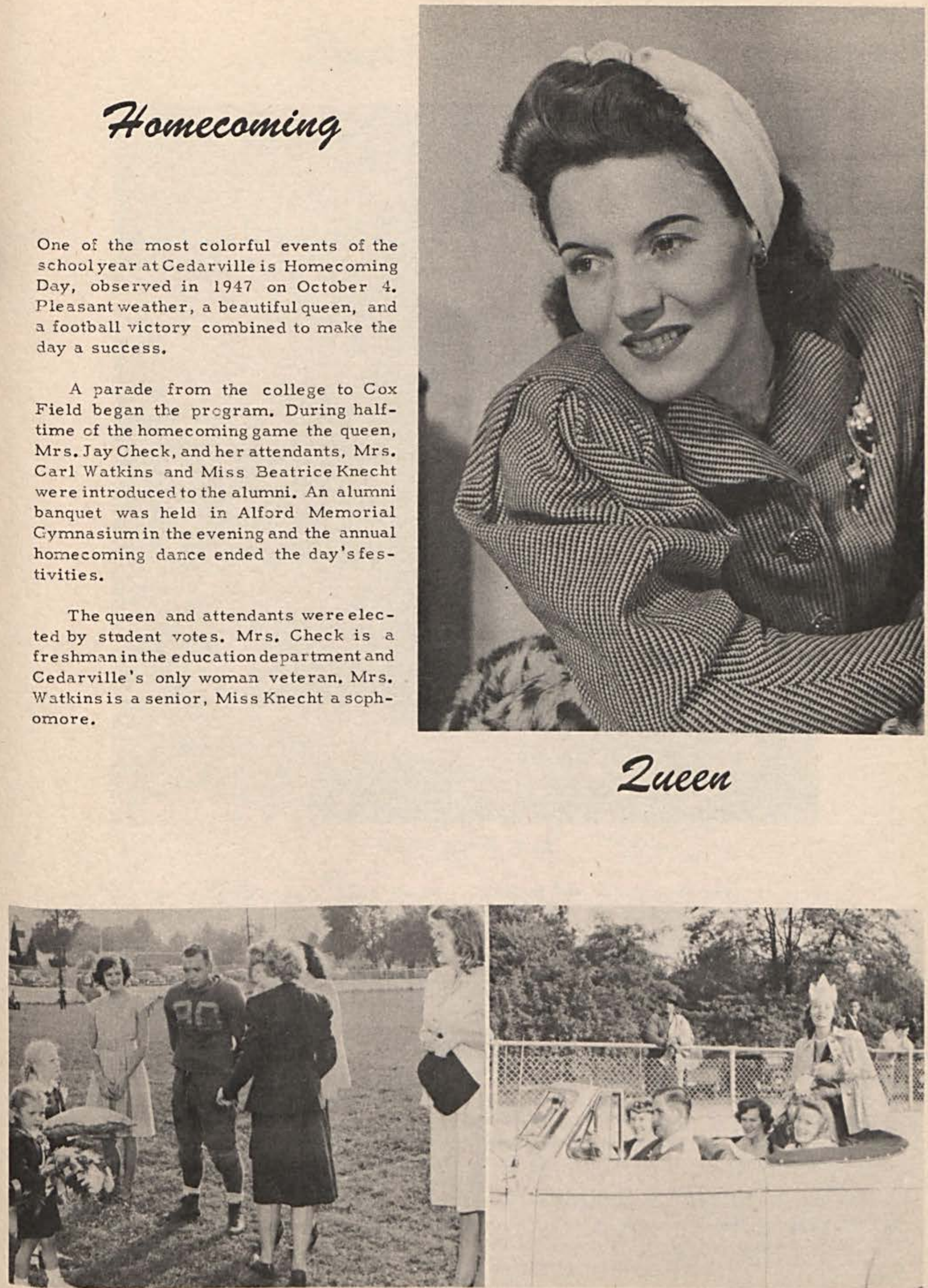


\section{In Memoriam}

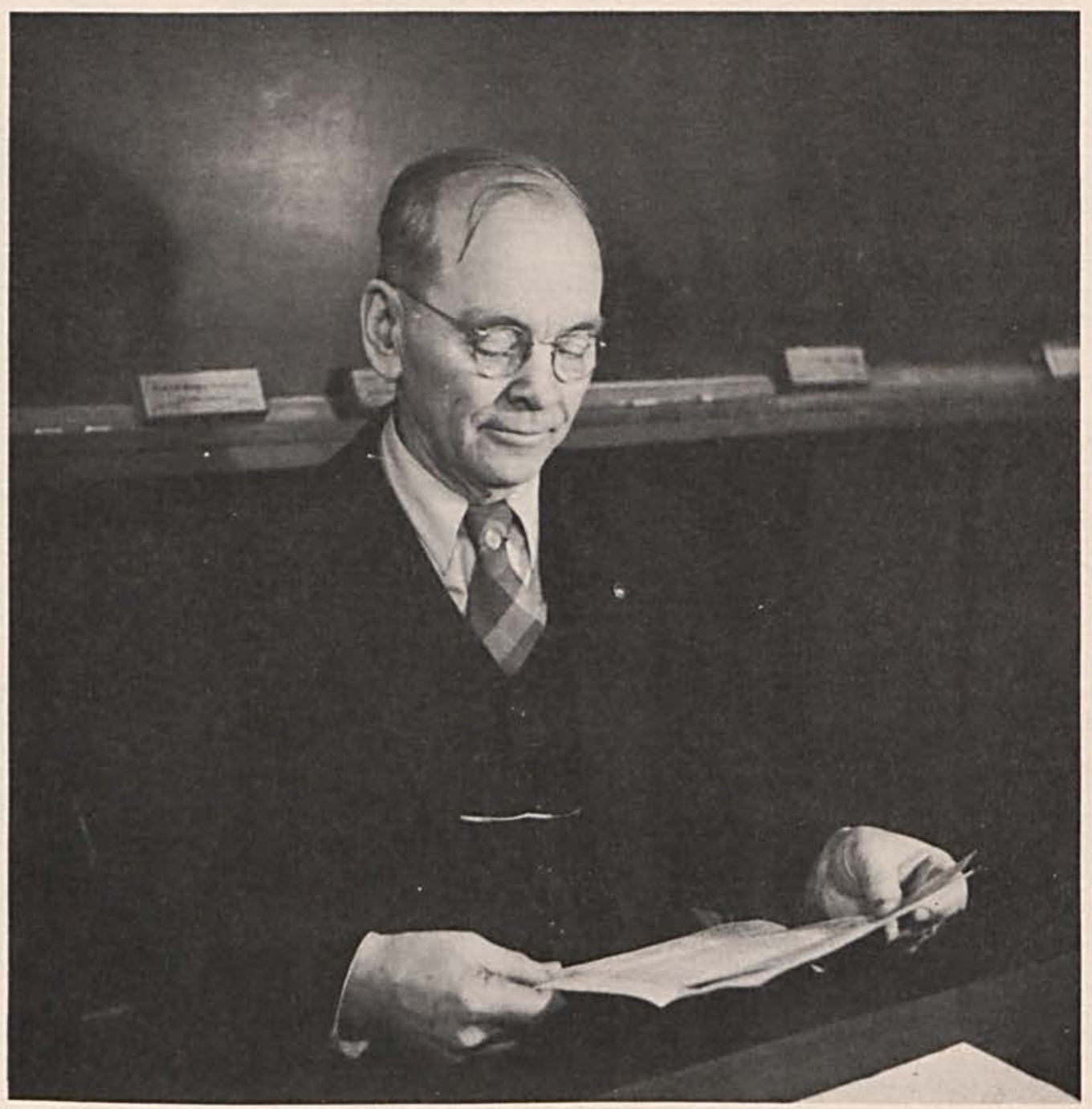

A. J. HOSTETLER

"None of us lives to himself, and none of us dies to himself. If we live, we live to the Lord, and if we die, we die to the Lord: so then, whether we live or whether we die, we are the Lord's. For to this end Christ died and lived again, that he might be Lord both of the dead and the living." Rom.14:7-9

Professor and Mrs. A. J. Hostetler met their death in an automobile accident on February 13, 1948. Professor Hostetler was Dean of Education at Cedarville College for the past twenty years. He taught many classes during that period and influenced hundreds of students.

His failure to pass an examination for certification as a teacher when he was seventeen may account for his later success. He was in turn a class-room teacher, principal, county school supervisor, director of a normal school, and finally dean of education at Cedarville. At his death, he had completed nearly fifty years of teaching. Many school superintendents eagerly sought graduates of Cedarville College, confident that they would have good character and a sound basis of scholarship.

One of his colleagues paid himaremarkable tribute when she said he was one of those rare teachers who can lift a student to heights of which he did not know himself capable. She congratulated the students who had been privileged to study with him. Long ago, two pupils said, "Did not our hearts burn within us, while he talked to us by the way and while he opened to us the scriptures?" 


\section{Board of Trustees}

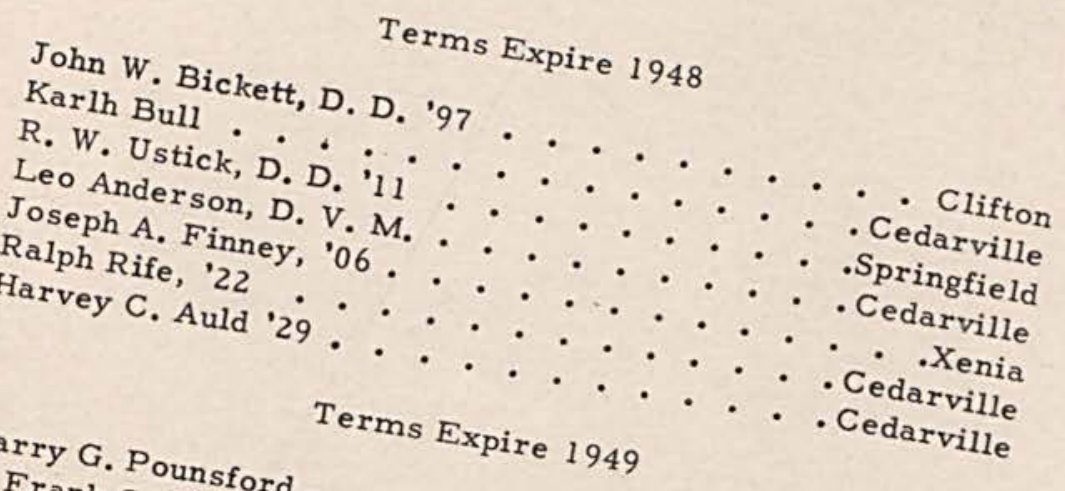

S. Frank Cresford.

Dwight R. Guthrie, '10.

Willard Barlow, '27.

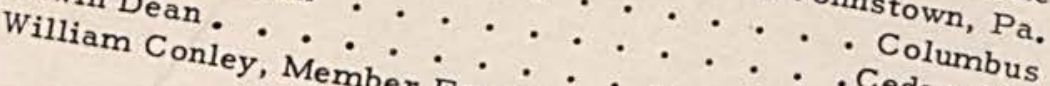

Terms Expire 1950

Wm. Iliff.

John L. Doraham, D. D. '05. . . . . . . Cedarville

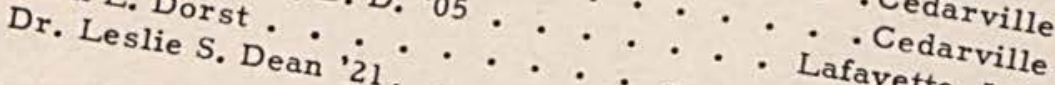

OFFICERS
Leoph A. Finney, '06 . . . Rocky River

$$
\text { OFFICERS }
$$

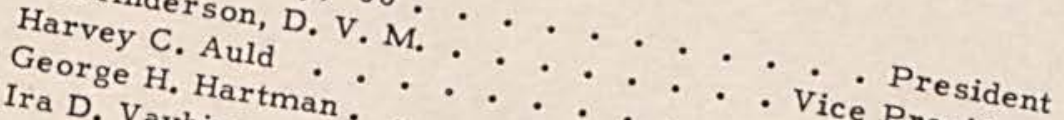

Ira D. Vayhinger, President . . . . Vice President 


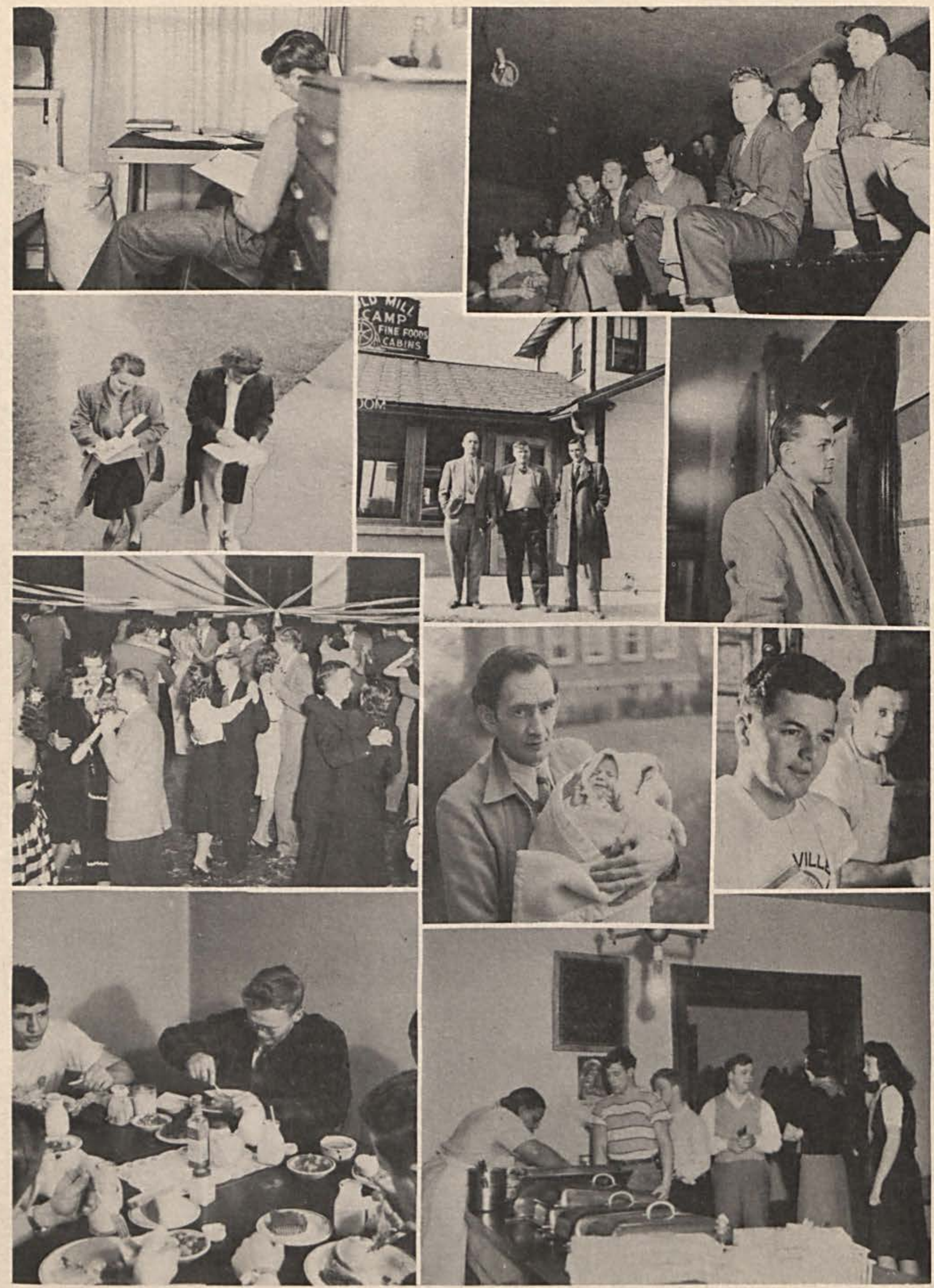




\section{ADVERTISING}

We are indeed grateful to the following advertisers

For their cooperation in making possible the publication of this annual.

The Cedrus Staff

COMPLIMENTS

OF

DE.AN'S ICE COMPANY

CEDARVILLE PROGRESSIVE CLUB

Phone 6-1563

CEDARVILLE, OHIO

LENNOX FURNACES

Coal, Oil, and Gas
COLEMAN FLOOR FURNACES

Oil and Gas

\section{COLEMAN AUTOMATIC HOT WATER HEATERS}

Oil and Gas, Installed

C. C. Brewer

Phone 6-2251

CEDARVILLE 


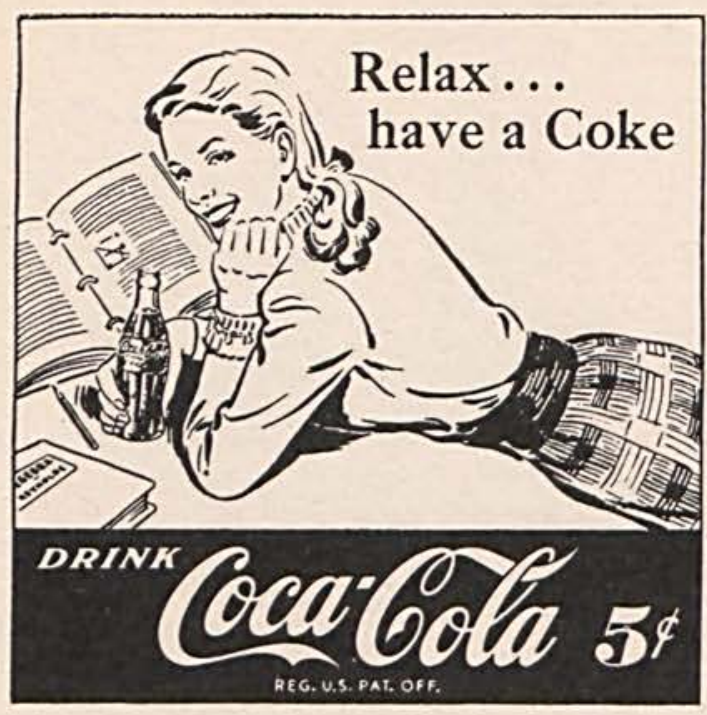

Bottled under authority of the Coca-Cola Company by

SPRINGFIELD COCA-COLA BOTTLING COMPANY
J. C. PENNEY CO., INC.

XENIA, OHIO

Men's and Women's

Ready to Wear

and Furnishings

Shoes

Dry Goods

THE TRIANGLE INN

(formerly Rainbow Inn)

UNDER NEW MANAGEMENT

HOME COOKING

Dinners, Short Orders, Plate Lunches Ice Cream and Soft Drinks

SOHIO GASOLINE AND OIL

Located by State Highway Roadside Park on Route $4211 / 2$ miles west of Cedarville, 6 miles east of Xenia

Open from 10:00 a. m. to 1:00 a. m. Herman Cottrell, Prop. 
WHOLESALE

JIM FLYNN INC.

Sporting Goods

Telephone HE 6329

Distributors for

RAWLINGS

WILSON

SPALDING

O'SHEA
We specialize in team equipment.

"WHERE SPORTSMEN SERVE SPORTSMEN"

Corner First and Jefferson Streets

DAYTON, OHIO

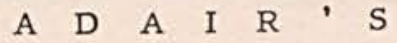

The Leading Home

Furnisher

For Over 60 Years

"WORTH A TRIP TO XENIA"

20-24 North Detroit Street

XENIA, OHIO $\underset{\text { COMPLIMENTS }}{\operatorname{OF}}$

THE CEDARVILLE BAKERY

"CLEAN CLOTHES" by

SPRINGFIELU LAUNDRY

Professional Laundry Service at its best

Leave Your Clothes with

CHAPLIN DRY CLEANERS

Cedarville Agent for Springfield Laundry 


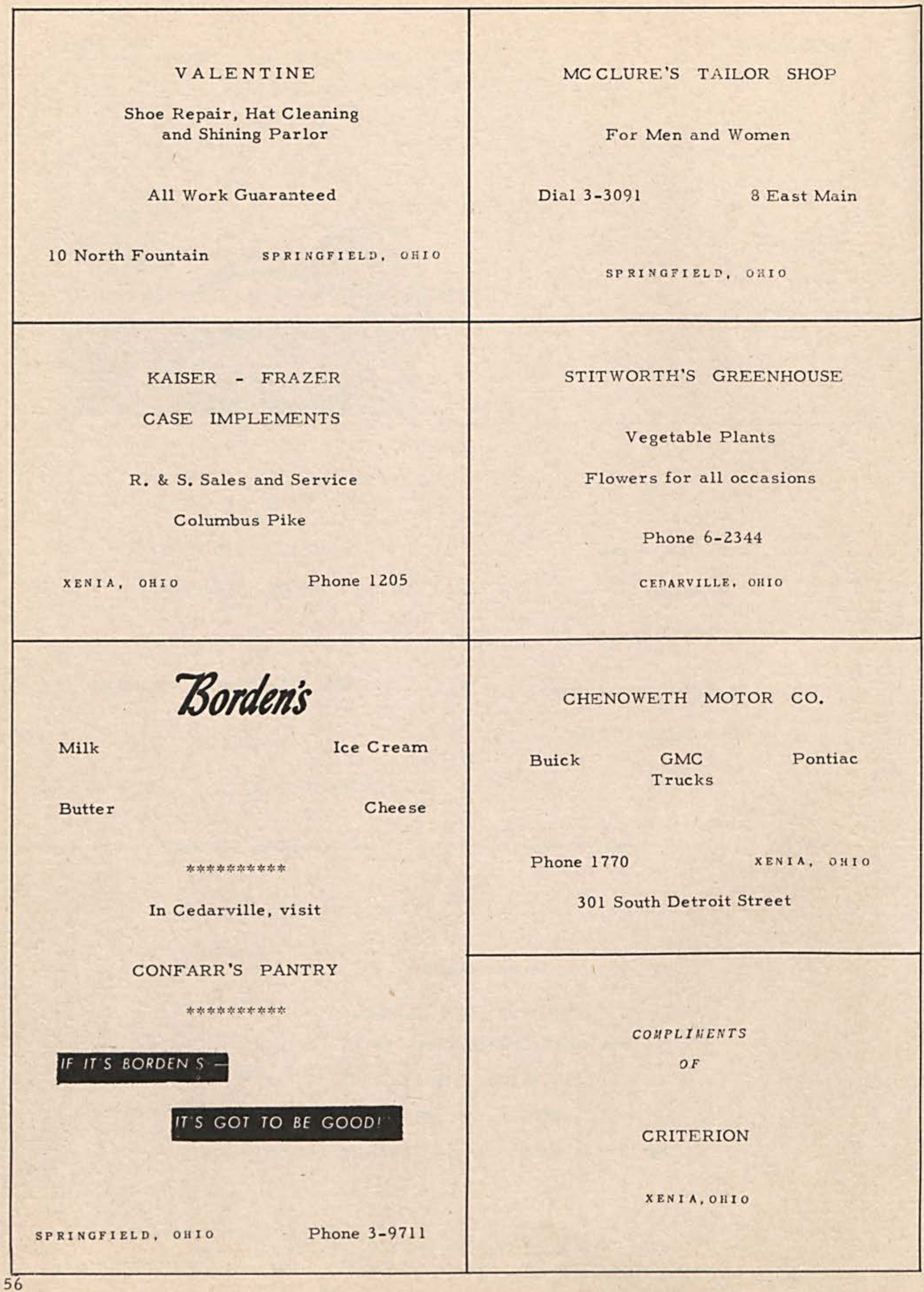




\section{CHRYSLER AND PLYMOUTH \\ MOPAR PARTS AND ACCESSORIES}

MARSHALL \& HARRISON MOTOR COMPANY

XENIA, OHIO

Phone 1508

COMPLIMENTS

OF THE

STAR BARBER SHOP

8 South Center SPRINGFIELD, ОНIO

COMPLIMENTS

$O F$

a friend

in

WESTPORT, CONNECTICUT

THE XENIA NATIONAL BANK

1835

Our Second Century of Banking

1948

Capital Surplus and Reserves

$\$ 556,000.00$

You are never a stranger after your first visit to our bank.

THE XENIA NATIONAL BANK

Corner Main and Detroit

XENIA, OHIO 
" WE SERVE TO SELL AGAIN"

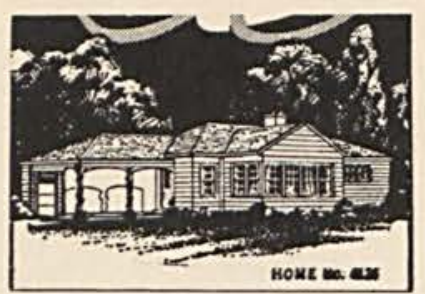

CEDARVILLE LUMBER CO.

Dealers in Quality Lumber

and Building Materials

Phone 6-1331

CEDARVILLE, OHIO

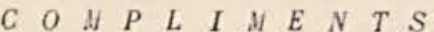

$O F$

T H E

C E D A R V I L L E H E R A L D
P I C K E R I N G E L E C T R I C

\section{Contractor-Dealer}

Philco Radios - Refrigerators

Hoover Cleaners

Easy Washers - Ironers

Westinghouse Appliances

Sunbeam Appliances

Electrical Supplies

Phone 6-1221

CEDARVILLE, OHIO
35 Greene Street

XENIA, OHIO 
B RO W $N^{\prime} S \quad D R$ U G S

THE REXALL STORE

College and Office Supplies

Photographic Supplies

Photo Finishing

H. H. BROWN

Phone 6-1771

$\begin{array}{lllllllllll}C & O & \text { ai } & P & L & I & M & E & N & T & S\end{array}$

O F

CHAPLIN DRY CLEANERS

Laundry

Hats Blocked

Shoe Repair Service

Residence Phone 6-2231

Main Street

CEDARVILLE, OHIO

CEDARVILLE, OHIO
BIRD VARIETY STORE

CEDARVILLE, ORIO

Wallpaper

Dry Goods Infants' Wear

Stationery

"THE FRIENDLY PLACE TO SHOP"

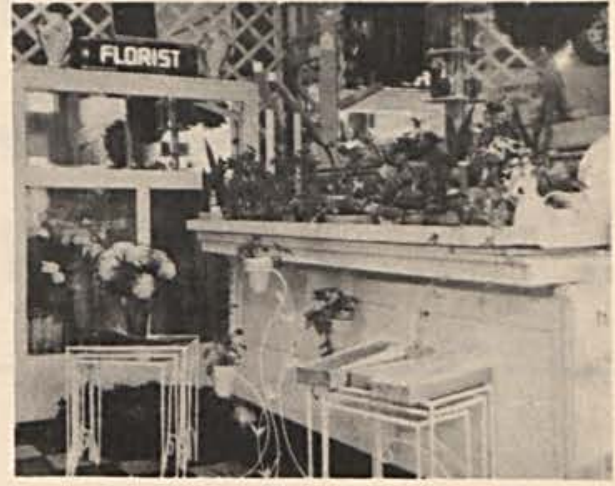

“ THE STORE WITH THE FRIENDLY SERVICE"

MANNING FLOWER SHOP

XENIA, OHIO

COMPLIMENTS OF

FRANK CRESWELL

COAL
Building Blocks Burial Vaults

CRESWELL CONCRETE PRODUCTS CO. 
THE CITIZENS NATIONAL BANK

Established 1881

Marching Forward With The Stride Of Youth

Phone 185

XENIA, OHIO
THE ADAMS-THUMA COMPANY

Lumber and Building Materials

Thumabuilt and Hog Lot Equipment

Phone 4-3811 JAMESTOWN, OHIO

\section{CLOTHING}

FURNISHINGS

SHOES
MCDORMAN'S

XENIA, OHIO
45 East Fourth

DAYTON, ОНIO
THE COMPLETE

SPORTING GOODS STORE $\oint \begin{aligned} & \text { HROYER' } \\ & \text { porting Good }\end{aligned}$

45 East Fourth

COMPLIMENTS

OF

a

friend
in

Washington C. H., Ohio 


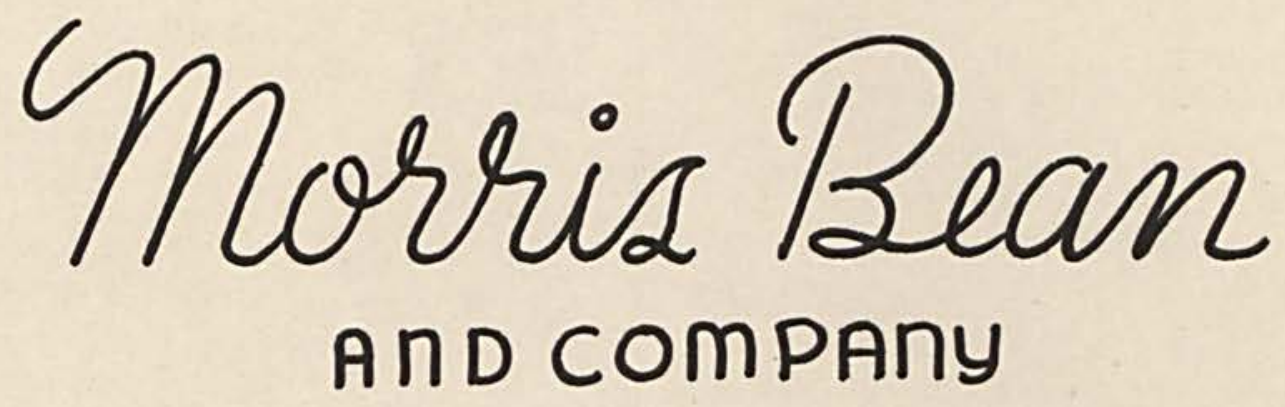

PLANTS

at

YELLOW SPRINGS AND CEDARVILLE

MANUFACUTRERS OF ALUMINUM CASTINGS

for

TIREMOLDS,

AIRCRAFT,

and many other purposes. 


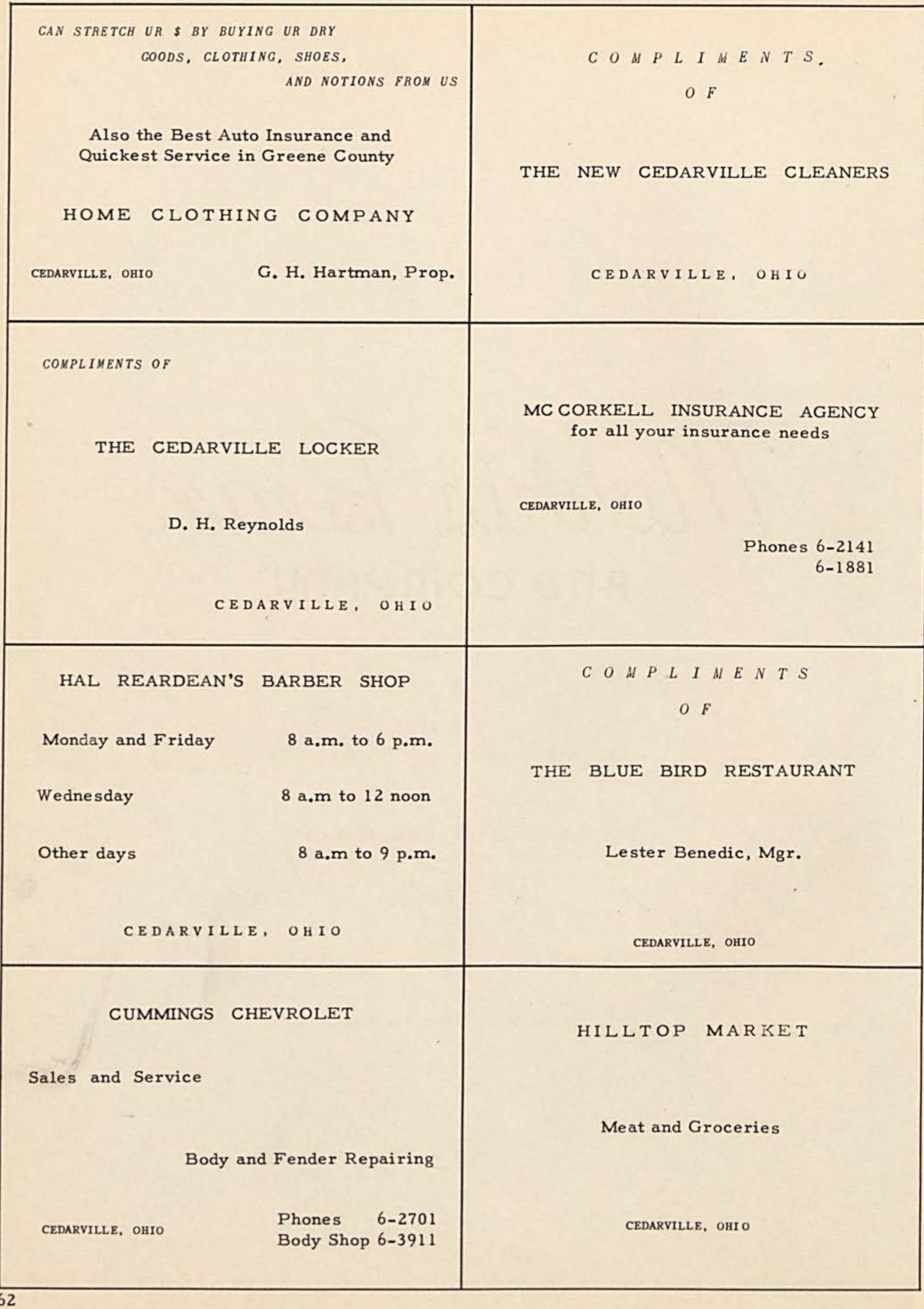




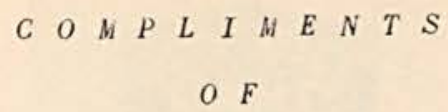

D U V A L L'S H A R D W A R E

\author{
CEDARVILLE, OHIO
}

GENERAL ELECTRIC APPLIANCES

PLUMBING

DUO-THERM STOVES

GENERAL HARDWARE

C O N F A R R' S P A N T R Y

CEDARVILLE, OHIO

Phone 6-2773

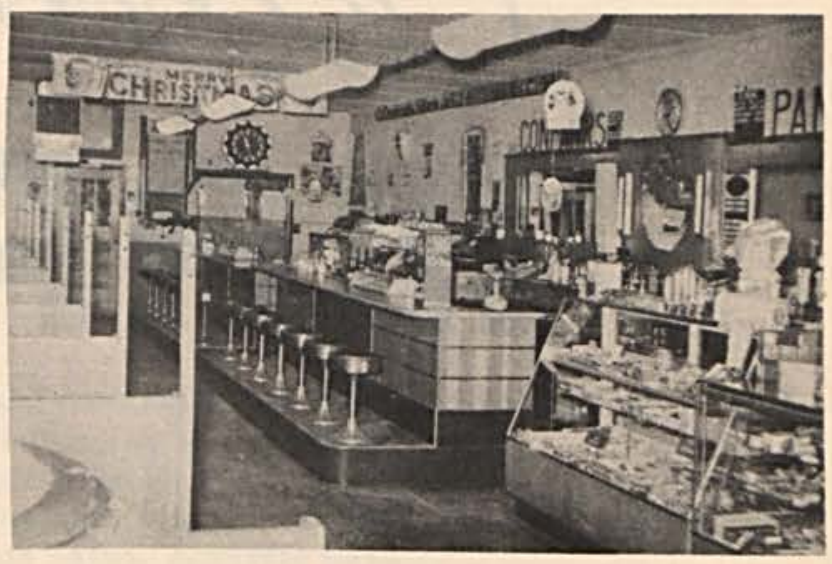

STUDENT HEADQUARTERS

$\begin{array}{lllllllllllllllllllllll}C & O & M & P & L & I & M & E & N & T & S\end{array}$

O F

H A R R Y S O W E R S

CANDIES 
COMPLIMENTS

$O F$

YOUR
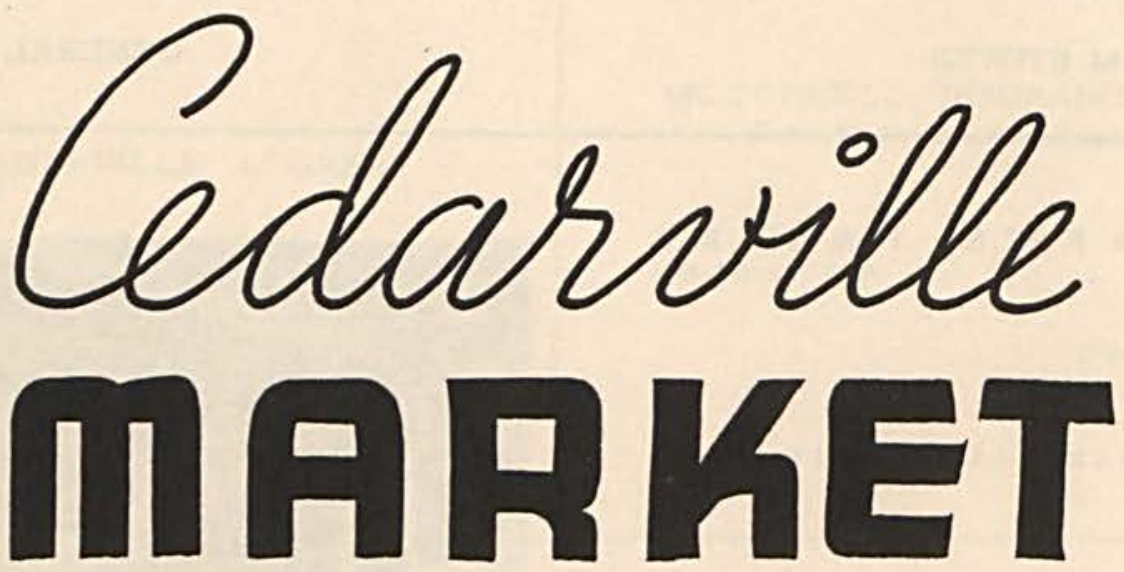

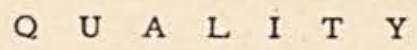

Foods

Meats

Fresh Meats

Fresh Vegetables

A Super "E" Market 


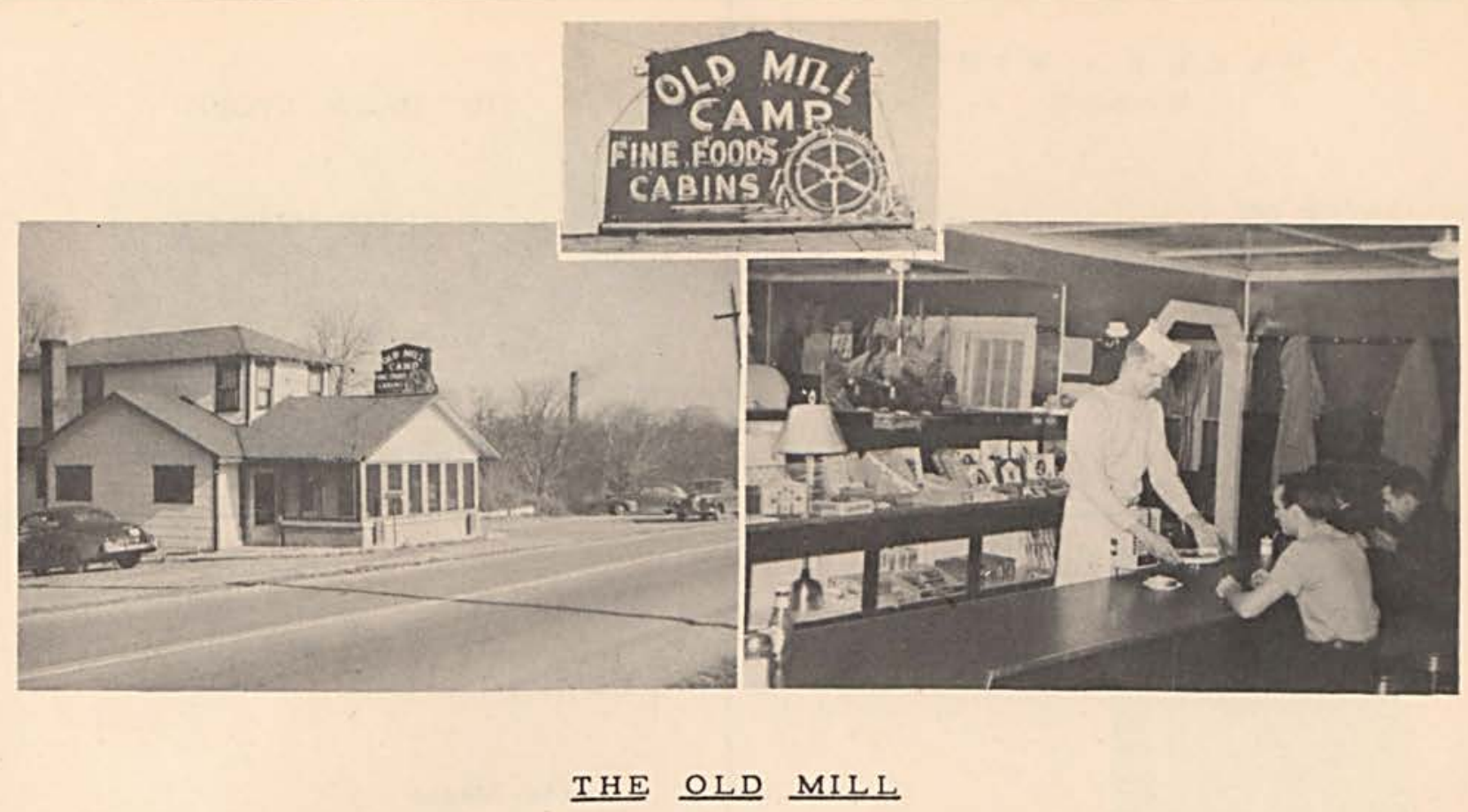

Route 42, between Xenia and Cedarville

Route 42 , between Xenia and Cedarville. 46 miles west of Columbus, 60 miles north of Cincinnati. A spot to Remember. Located on Massie's Creek Gorge at the falls. Breakfast, Lunch, Dinner. Modern cabins with private baths. Electric heat.

C O N G R A T U L A T I O N

T O

T H E

C L A S S

O F

$\begin{array}{llll}1 & 9 & 4 & 8\end{array}$ 


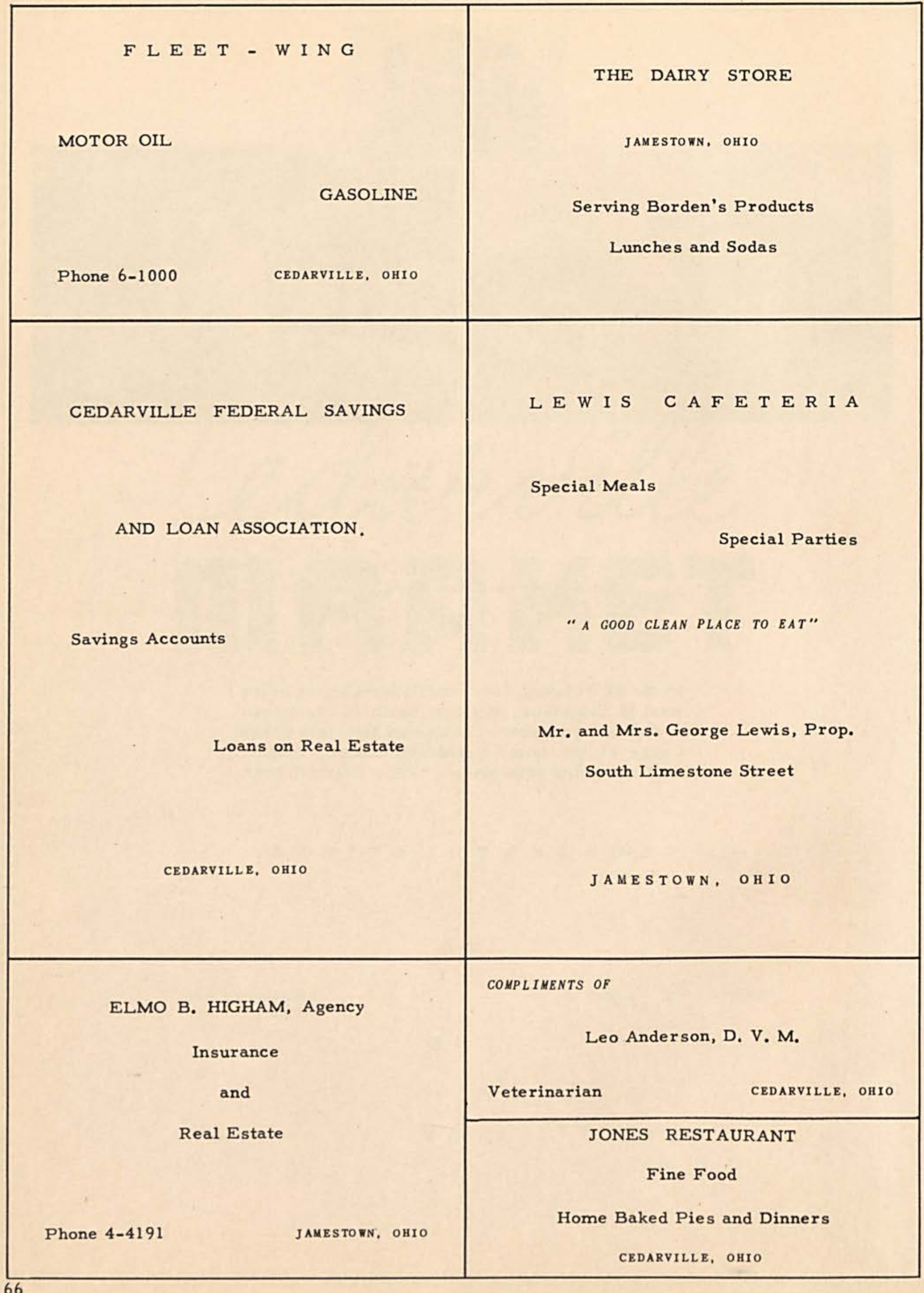




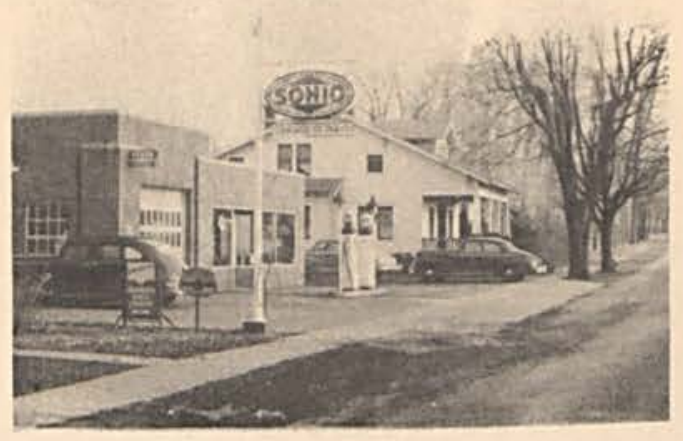

Dodge -- Plymouth

Sales and Service

Standard Oil Products

PAUL EDWARDS

South Main Street

Cedarville, Ohio
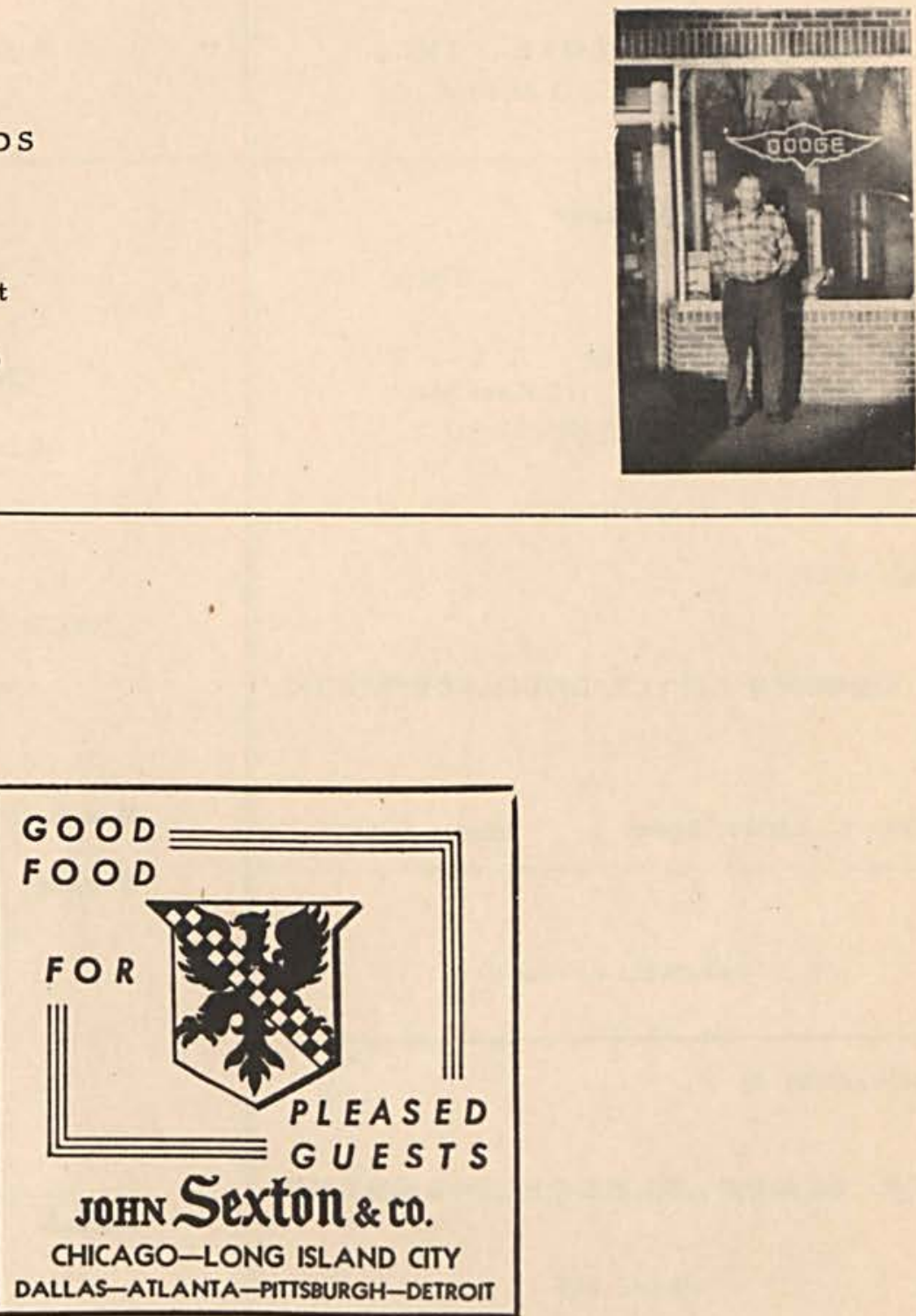


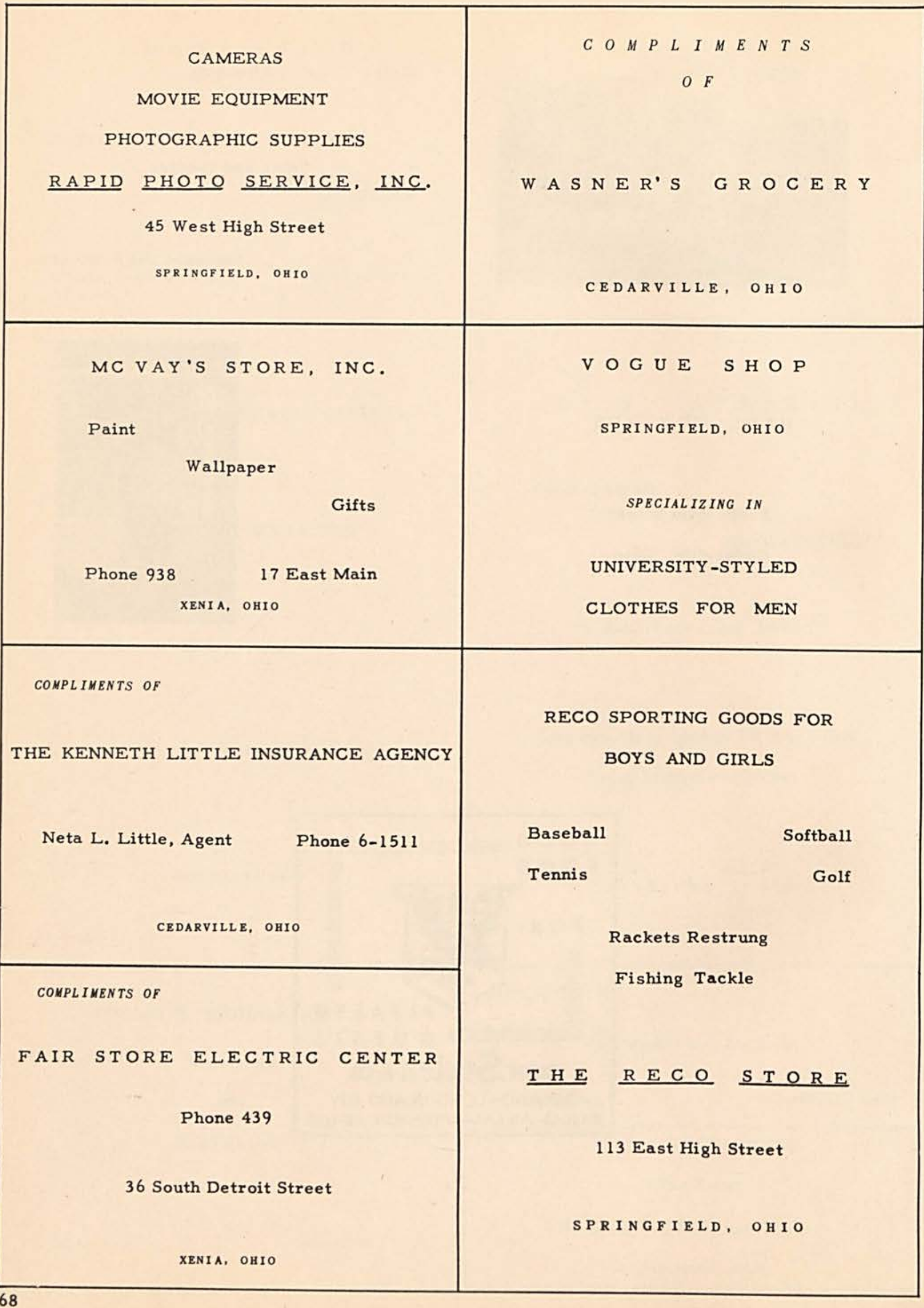




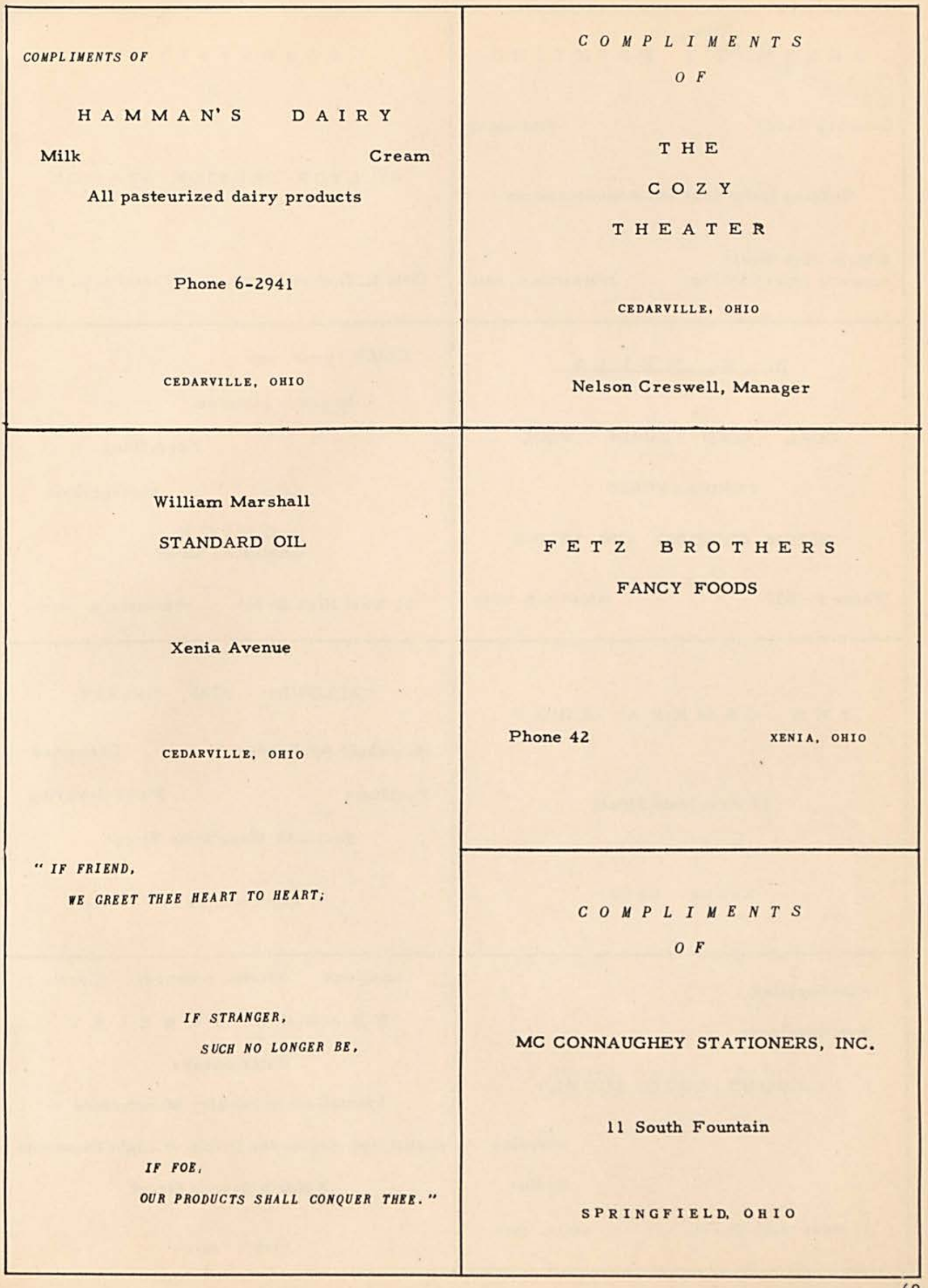




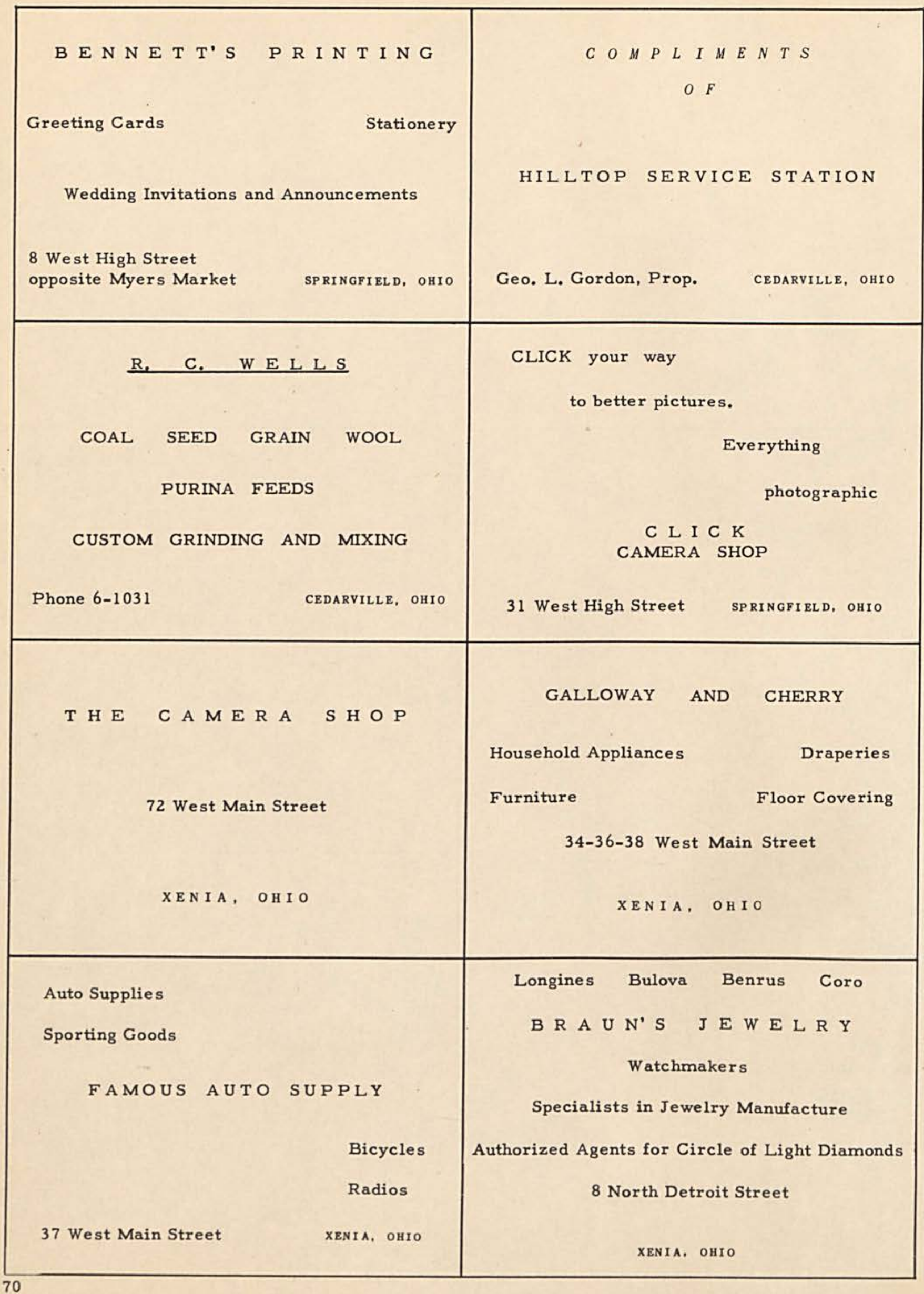





$$
\text { futographe }
$$

72 


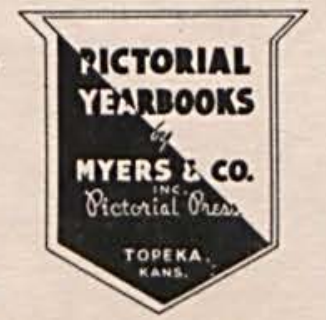




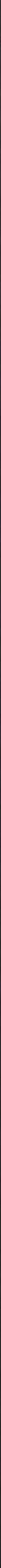




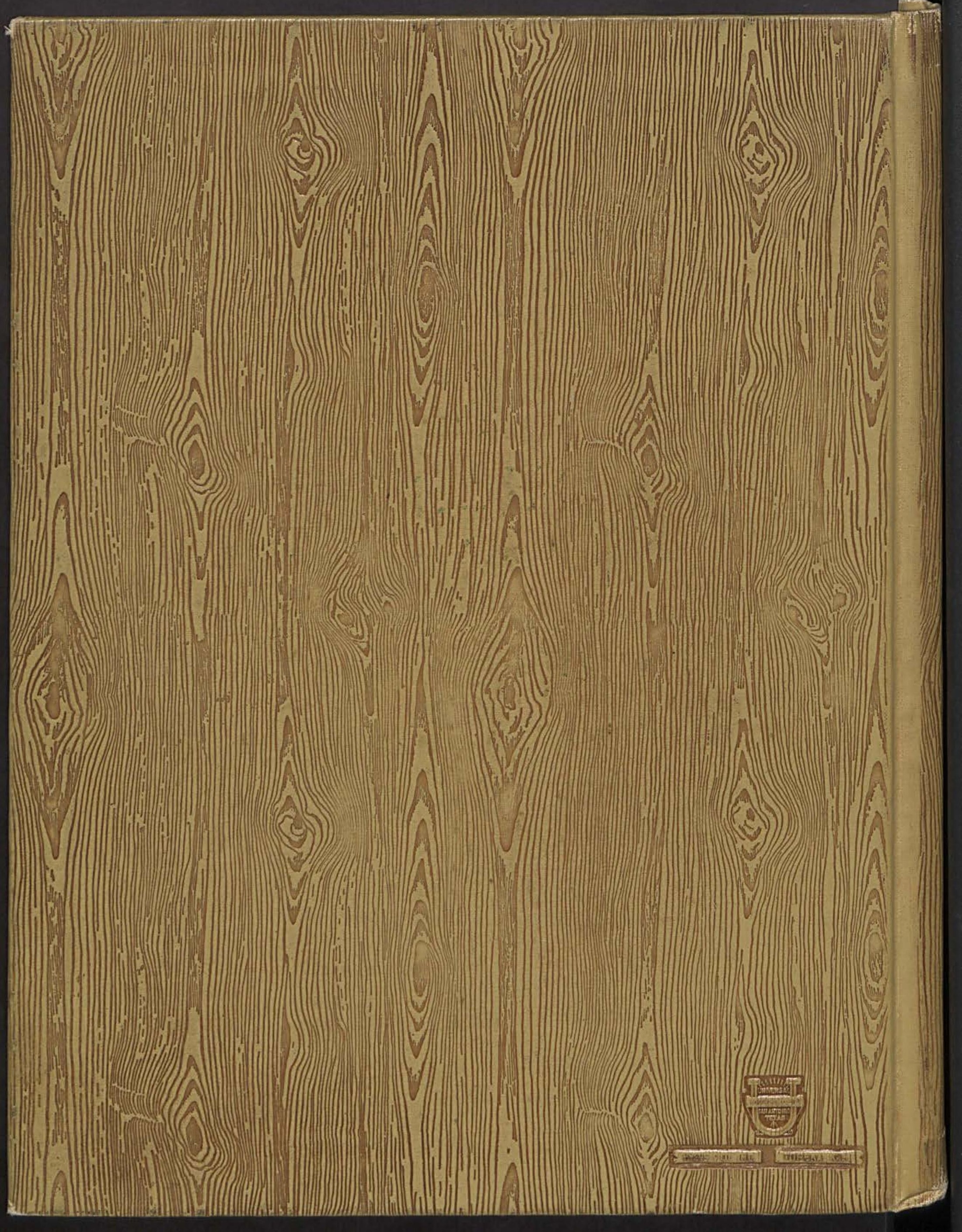

